\author{
Monograph \\ urn:lsid:zoobank.org:pub:C3C851C3-0F12-412C-A15B-56F0F263CD00
}

\title{
Revision of the poorly known Neotropical butterfly genus Zischkaia Forster, 1964 (Lepidoptera, Nymphalidae, Satyrinae), with descriptions of nine new species
}

\author{
Shinichi NAKAHARA ${ }^{1, *}$, Thamara ZACCA ${ }^{2}$, Fernando M.S. DIAS ${ }^{3}$, \\ Diego R. DOLIBAINA ${ }^{4}$, Lei XIAO ${ }^{5}$, Marianne ESPELAND ${ }^{6}$, Mirna M. CASAGRANDE ${ }^{7}$, \\ Olaf H.H. MIELKE ${ }^{8}$, Gerardo LAMAS ${ }^{9}$, Blanca HUERTAS ${ }^{10}$, Kaylin KLECKNER ${ }^{11}$ \& \\ Keith R. WILLMOTT ${ }^{12}$ \\ 1,5,11,12 McGuire Center for Lepidoptera and Biodiversity, Florida Museum of Natural History, \\ University of Florida, Gainesville, Florida 32611, USA. \\ ${ }^{1,11}$ Department of Entomology and Nematology, University of Florida, Gainesville, Florida 32611, USA. \\ ${ }^{2}$ Departamento de Biologia Animal and Museu de Zoologia, Instituto de Biologia, \\ Universidade Estadual de Campinas, Campinas, São Paulo, Brazil. \\ 3,4,7,8 Laboratório de Estudos de Lepidoptera Neotropical, Departamento de Zoologia, \\ Universidade Federal do Paraná, Curitiba, Paraná, Brazil. \\ ${ }^{6}$ Arthropoda Department, Zoological Research Museum Alexander Koenig, \\ Adenauer Allee 160, 53113 Bonn, Germany. \\ ${ }^{1,9}$ Departamento de Entomología, Museo de Historia Natural, \\ Universidad Nacional Mayor de San Marcos, Lima, Peru. \\ ${ }^{10}$ Life Sciences Department, Natural History Museum, London, UK.

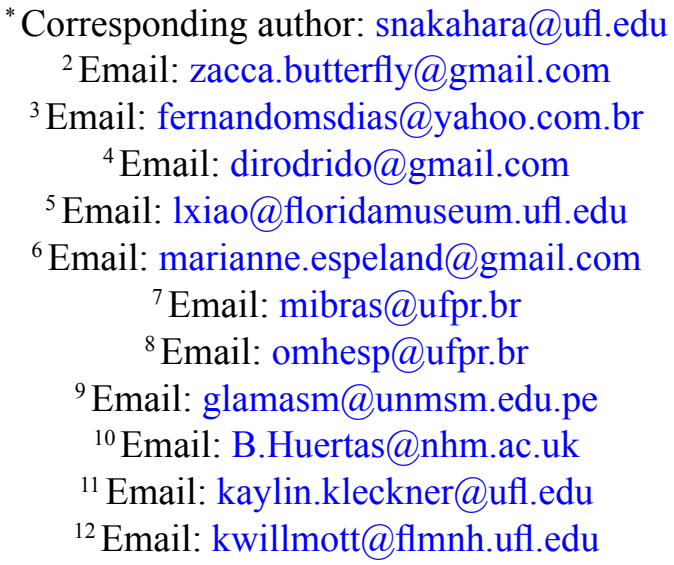 \\ ${ }^{1}$ urn:1sid:zoobank.org:author:A7240997-442C-41C7-9B20-D8D4AE31AED9 \\ ${ }^{2}$ urn:1sid:zoobank.org:author:EBE99273-B02D-4A17-AD52-5BB3DFBA6C85 \\ ${ }^{3}$ urn:1sid:zoobank.org:author:FA0950D9-DC58-4230-8180-F26CB5788E55 \\ ${ }^{4}$ urn:lsid:zoobank.org:author:0A762FB6-AF41-4A09-9DF8-6F3954BA8956 \\ ${ }^{5}$ urn:lsid:zoobank.org:author:4233F498-4D30-428A-B2A4-A6A76DC5FCA4 \\ ${ }^{6}$ urn:1sid:zoobank.org:author:00D6F9F9-3902-4A8B-846F-720AB32922A6
}




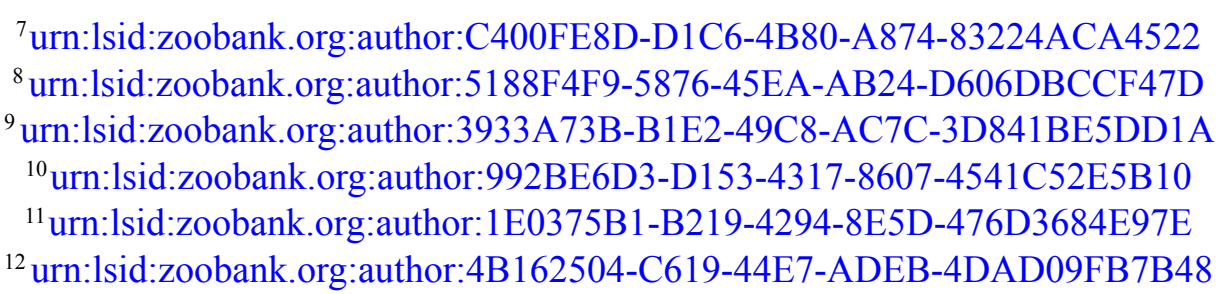

\begin{abstract}
We provide the first comprehensive taxonomic revision of the poorly known South American butterfly genus Zischkaia Forster, 1964, hitherto regarded as including three described species. A phylogenetic analysis based on DNA sequence data shows that Zischkaia is monophyletic and consists of two morphologically diagnosable clades. Morphological characters and DNA 'barcodes' support the recognition of twelve species in the genus, a significant increase even for the relatively poorly studied subtribe Euptychiina. Consequently, nine new species are described and named herein, including Z. arctoa Nakahara, sp. nov., Z. chullachaki Nakahara \& Zacca, sp. nov., Z. baku Zacca, Dolibaina \& Dias, sp. nov., Z. arenisca Nakahara, Willmott \& Hall, sp. nov., Z. argyrosflecha Nakahara, L. Miller \& Huertas, sp. nov., Z. abanico Nakahara \& Petit, sp. nov., Z. josti Nakahara \& Kleckner, sp. nov., Z. mielkeorum Dolibaina, Dias \& Zacca, sp. nov. and Z. warreni Dias, Zacca \& Dolibaina, sp. nov. In addition, a neotype is designated for Satyrus pacarus Godart, [1824], and lectotypes are designated for Euptychia amalda Weymer, 1911, Euptychia fumata Butler, 1867 and Euptychia saundersii Butler, 1867.
\end{abstract}

Key words. DNA "barcodes", Euptychiina, monophyletic, Neotropical region, systematics, taxonomy.

Nakahara S., Zacca T., Dias F.M.S., Dolibaina D.R., Xiao L., Espeland M., Casagrande M.M., Mielke O.H.H., Lamas G., Huertas B., Kleckner K. \& Willmott K.R. 2019. Revision of the poorly known Neotropical butterfly genus Zischkaia Forster, 1964 (Lepidoptera, Nymphalidae, Satyrinae), with descriptions of nine new species. European Journal of Taxonomy 551: 1-67. https://doi.org/10.5852/ejt.2019.551

\title{
Introduction
}

Zischkaia Forster, 1964 has hitherto been regarded as a relatively small genus of three species, placed in the satyrine subtribe Euptychiina Reuter (Lamas 2004; Freitas et al. 2018). Among the 33 euptychiine genera that he described in the same paper, Forster (1964) described Zischkaia and designated Euptychia fumata Butler, 1867 (the date was erroneously given as 1857 by Forster) as the type species, recognizing two other species in this genus, namely Euptychia amalda Weymer, 1911 and Euptychia saundersii Butler, 1867. Subsequently, Lamas (2004) also included Satyrus pacarus Godart, [1824] and Euptychia mima Butler, 1867, in addition to recognizing one undescribed species and placing E. fumata (the type species of the genus) as a junior subjective synonym of $Z$. pacarus. However, Lamas (2004) did not provide any justification for the placement of these taxa in Zischkaia, this decision presumably being based on their similar ventral wing patterns. Euptychia mima was recently transferred to Nhambikuara Freitas, Barbosa \& Zacca, 2018 (Freitas et al. 2018). Members of Zischkaia have an entirely Cis-Andean distribution and all of them are medium-sized (forewing length roughly $20-30 \mathrm{~mm}$ ), uniformly brown butterflies marked with relatively large ventral hindwing ocelli, which therefore appear to be typical, drab euptychiine butterflies. However, compared to many other common euptychiine genera, species of Zischkaia are poorly represented in almost all museum collections, hindering taxonomic study and resulting in the genus remaining poorly understood. Although a number of other euptychiine genera have been the focus of taxonomic and/or systematic studies after the checklist of Lamas (2004), especially in recent years (e.g., Barbosa et al. 2015; Zacca et al. 2017; Nakahara et al. 2018c), partly as a result of the lack of material deposited in collections, Zischkaia has received no attention by butterfly researchers until now. A taxonomic revision for this group is therefore in urgent need, given the similarities among 
the species of Zischkaia and consequent difficulties in identification, and the potential significance of the group for biogeographic and conservation research as a result of the highly restricted geographic ranges of some species.

This paper is part of a planned series of publications by some of the authors (SN, TZ and KW) to revise a number of taxonomically problematic genera in the nymphalid subtribe Euptychiina. The past few years have seen an explosion of interest in euptychiine systematics (e.g., Cong \& Grishin 2014; Barbosa et al. 2015; Zacca et al. 2017, 2018; Nakahara et al. 2015a, 2015b, 2018b, 2018c, 2019; Willmott et al. 2019; see also http://www.flmnh.ufl.edu/museum-voices/euptychiina/), where the need for generic revisions and revisionary systematic study in this subtribe has been discussed in several publications (e.g., Marín et al. 2011). This study towards revising the genus Zischkaia was originally initiated by FD and DD, although this plan was halted due to the inaccessibility of the types of some taxa. Recently, SN initiated a complete revision of the genus, partly to contribute towards a better overall understanding of the systematics and diversity of Euptychiina. This collaborative study has enabled us to satisfactorily review what is known about the genus, as a first step towards understanding the true species diversity of the group. As a result, we regard Zischkaia as containing twelve species, remarkably with nine of them described and named herein. A neotype is designated for Satyrus pacarus and lectotypes are designated for Euptychia amalda, E. fumata and E. saundersii.

\section{Material and methods}

\section{Morphological study}

Legs, labial palpi, and abdomens were soaked in hot $\mathrm{KOH}$ solution for 5-10 minutes prior to dissection, dissected, and subsequently stored in glycerine. Dissection information regarding genitalia of Zischkaia can be found in Table 1. Drawings of external morphology were done using a camera lucida attached to either Leica MZ 16 stereoscopic microscope (at MGCL) or Nikon SMZ2800 (at MUSM). Images of genitalia taken at MGCL were taken with an Auto-montage Pro 5.01 system (Synoptics Ltd.) using a JVC digital camera (model KY-F65U) and Leica Z16APO lens, except for female genitalia of $Z$. arenisca Nakahara, Willmott \& Hall, sp. nov. which were photographed using Helicon Focus 6.7.1 using Canon EOS 6D, subsequently stacked using Helicon Remote (ver. 3.8.7 W); photos of male and female genitalia were obtained at DZUP in Leica LAS 3D view and LAS montage version 4.7 with the aid of a video camera Leica DFC 500 attached to a stereoscopic microscope Leica MZ16. Illustrations of venation were prepared with the aid of a camera lucida attached to a stereoscopic microscope and subsequently vectorized by using the software GIMP version 2.8.10 (GIMP team 2016) (for female Z. pacarus (Godart, 1824)) and CorelDRAW X5 (for Z. saundersii (Butler, 1867)), in addition to tracing line drawing by ink and subsequently modified using Adobe Photoshop CC 2017 (for male Z. pacarus). A JEOL JSM-5510LV Scanning Electron Microscope (SEM) was used to take images of androconial scales.

Terminology for wing venation follows the Comstock \& Needham (1898) system described in Miller (1970: 46), and terminology for wing pattern elements follows Zacca et al. (2018). Nomenclature of genitalia mostly follows Klots (1956), although we also follow Muschamp (1915) for the term "brachia"; we follow Austin \& Mielke (2008) in referring to the part of the genitalia typically termed the "vinculum" as the "combined ventral arms of tegumen and dorsal arms of saccus" (see Nakahara et al. 2015a, for more details); Nakahara et al. (2018b) is followed for those terms related to phallus. Finally, we apply the term 'sclerotized tube' to the sclerotized portion of ductus bursae, which appears somewhat as a continuation of the lamella antevaginalis, since this character is useful in distinguishing species in the "pacarus clade" and we hope that this term will permit clearer understanding of species diagnoses. The term antrum (sensu Klots 1956) might apply to this particular structure, but further discussion of terminology is beyond the scope of this article. 
Table 1 (continued on next page). A list of dissected specimens of Zischkaia Forster, 1964 for this study.

\begin{tabular}{|c|c|c|c|c|c|}
\hline Taxon & Sex & Genitalia dissection ID & Voucher No. & Repository & Locality (Country) \\
\hline Z. amalda & $\hat{\sigma}$ & SN-17-21 & N/A (LT) & ZSM & Bolivia \\
\hline Z. amalda & $\hat{0}$ & SN-17-8 & 1036040 & FLMNH/MGCL & Peru \\
\hline Z. arctoa & $\hat{\sigma}$ & SN-17-9 & 1036041 & FLMNH/MGCL & Venezuela \\
\hline Z. arctoa & $\hat{0}$ & $\mathrm{SN}-17-73$ & 1036042 & FLMNH/MGCL & Venezuela \\
\hline Z. chullachaki & $\hat{0}$ & $\mathrm{SN}-17-5$ & 1036033 & FLMNH/MGCL & Peru \\
\hline Z. chullachaki & $\hat{0}$ & SN-17-75 & 1036037 & FLMNH/MGCL & Peru \\
\hline Z. chullachaki & $\hat{0}$ & SN-17-66 & 1036039 & FLMNH/MGCL & Peru \\
\hline Z. chullachaki & $\hat{0}$ & N/A & 21627 & DZUP & Brazil \\
\hline Z. chullachaki & q & N/A & 37003 & DZUP & Brazil \\
\hline Z. chullachaki & o & N/A & 36508 & DZUP & Brazil \\
\hline Z. chullachaki & $\hat{\sigma}$ & N/A & 21620 & DZUP & Brazil \\
\hline Z. chullachaki & $\hat{\sigma}$ & N/A & 21228 & DZUP & Peru \\
\hline Z. baku & $\hat{0}$ & $\mathrm{~N} / \mathrm{A}$ & MGCL-LOAN 201 & ZUEC & Brazil \\
\hline Z. baku & $\hat{0}$ & N/A & MGCL-LOAN 292 & ZUEC & Brazil \\
\hline Z. baku & 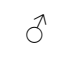 & SN-17-10 & 1036015 & FLMNH/MGCL & Brazil \\
\hline Z. baku & 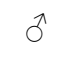 & SN-17-64 & 1036018 & FLMNH/MGCL & Brazil \\
\hline Z. baku & $\hat{0}$ & SN-17-63 & 1036022 & FLMNH/MGCL & Brazil \\
\hline Z. baku & q & $\mathrm{SN}-17-65$ & 1036029 & FLMNH/MGCL & Brazil \\
\hline Z. baku & $\hat{0}$ & N/A & 5573 & DZUP & Brazil \\
\hline Z. baku & $\delta$ & $\mathrm{N} / \mathrm{A}$ & 5572 & DZUP & Brazil \\
\hline Z. baku & 우 & N/A & 5571 & DZUP & Brazil \\
\hline Z. baku & $\hat{\sigma}$ & M-2239 J.Y. Miller & 1036032 & FLMNH/MGCL & Brazil \\
\hline Z. arenisca & $\hat{\sigma}$ & SN-17-16 & 1036290 & FLMNH/MGCL & Ecuador \\
\hline Z. arenisca & $\delta$ & SN-17-74 & 1036291 & FLMNH/MGCL & Ecuador \\
\hline Z. arenisca & ㅇ & SN-17-174 & 149623 & FLMNH/MGCL & Ecuador \\
\hline Z. arenisca & q & SN-16-73 & 105658 & MUSM & Peru \\
\hline Z. arenisca & q & $\mathrm{SN}-19-32$ & 297321 & FLMNH/MGCL & Ecuador \\
\hline Z. argyrosflecha & $\hat{\sigma}$ & M-9142 Lee D. Miller & N/A & MNHU & Peru \\
\hline Z. argyrosflecha & $\hat{\sigma}$ & $\mathrm{N} / \mathrm{A}$ & 1718076 & NHMUK & Peru \\
\hline Z. pacarus & $\hat{\sigma}$ & $\mathrm{N} / \mathrm{A}$ & 21207 & DZUP & Brazil \\
\hline Z. pacarus & $\hat{\sigma}$ & N/A & 5578 & DZUP & Brazil \\
\hline Z. pacarus & $\hat{\sigma}$ & $\mathrm{N} / \mathrm{A}$ & 36989 & DZUP & Brazil \\
\hline Z. pacarus & q & $\mathrm{N} / \mathrm{A}$ & 36841 & DZUP & Brazil \\
\hline Z. pacarus & q & $\mathrm{N} / \mathrm{A}$ & 5577 & DZUP & Brazil \\
\hline Z. pacarus & q & N/A & 36881 & DZUP & Brazil \\
\hline Z. pacarus & $\hat{\sigma}$ & SN-17-6 & 1036004 & FLMNH/MGCL & Brazil \\
\hline Z. pacarus & q & SN-17-72 & 1036005 & FLMNH/MGCL & Brazil \\
\hline Z. abanico & 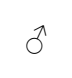 & $\begin{array}{c}\text { prep. genit. } 575 \\
19.07 .2017 / \text { J.Lorenc }\end{array}$ & 11926 & MZUJ & Ecuador \\
\hline Z. abanico & $\hat{\sigma}$ & N/A & 10430711 & NHMUK & Colombia \\
\hline Z. saundersii & q & N/A & 36969 & DZUP & Peru \\
\hline
\end{tabular}


Table 1 (continued).

\begin{tabular}{|c|c|c|c|c|c|}
\hline Taxon & Sex & Genitalia dissection ID & Voucher No. & Repository & Locality (Country) \\
\hline Z. saundersii & $\hat{0}$ & $\mathrm{~N} / \mathrm{A}$ & 21221 & DZUP & Peru \\
\hline Z. saundersii & 우 & $\mathrm{N} / \mathrm{A}$ & 5580 & DZUP & Peru \\
\hline Z. saundersii & $\widehat{0}$ & $\mathrm{~N} / \mathrm{A}$ & 5579 & DZUP & Peru \\
\hline Z. saundersii & $0^{\lambda}$ & $\mathrm{N} / \mathrm{A}$ & 38159 & DZUP & Brazil \\
\hline Z. josti & 우 & N/A & N/A (HT) & NMBE & Venezuela \\
\hline Z. josti & 우 & 2018-002 D.J.Harvey & 233844 & USNM & Guyana \\
\hline Z. mielkeorum & 0 & $\mathrm{~N} / \mathrm{A}$ & 36599 & DZUP & Brazil \\
\hline Z. mielkeorum & 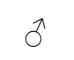 & $\mathrm{N} / \mathrm{A}$ & 21200 & DZUP & Brazil \\
\hline Z. mielkeorum & 우 & $\mathrm{N} / \mathrm{A}$ & 36688 & DZUP & Brazil \\
\hline Z. mielkeorum & q & $\mathrm{N} / \mathrm{A}$ & 36711 & DZUP & Brazil \\
\hline Z. warreni & $\hat{0}$ & $\mathrm{~N} / \mathrm{A}$ & 21214 & DZUP & Brazil \\
\hline Z. warreni & q & $\mathrm{N} / \mathrm{A}$ & 36731 & DZUP & Brazil \\
\hline Z. warreni & 우 & $\mathrm{N} / \mathrm{A}$ & 36669 & DZUP & Brazil \\
\hline Z. warreni & 우 & $\mathrm{N} / \mathrm{A}$ & 36689 & DZUP & Brazil \\
\hline Z. warreni & $0^{\lambda}$ & SN-17-7 & 1036043 & FLMNH/MGCL & Brazil \\
\hline Z. warreni & 우 & SN-17-172 & 1036044 & FLMNH/MGCL & Brazil \\
\hline
\end{tabular}

A total of 384 specimens were studied and the following 22 collection acronyms are used throughout this article.

\section{Institutional acronyms}

$\mathrm{ADW}=$ Andrew David Warren collection, Castle Rock, USA

$\mathrm{AMNH}=$ American Museum of Natural History, New York, USA

BEJO = Bernhard Jost collection, Münsingen, Switzerland

DATR = David Trembath collection, Dorking, UK

$\mathrm{DD}=$ Diego Rodrigo Dolibaina collection, Curitiba, Brazil

DZUP = Coleção Pe. Jesus Santiago Moure, Departamento de Zoologia, Universidade Federal do Paraná, Curitiba, Brazil

FLMNH $=$ McGuire Center for Lepidoptera and Biodiversity (MGCL), Florida Museum of Natural History, Gainesville, USA

HAWA = Haydon Warren-Gash collection, London, UK

INABIO = Instituto Nacional de Biodiversidad, Quito, Ecuador (formerly MECN)

JEPE = Jean-Claude Petit collection, Ducy, France

MECN = Museo Ecuatoriano de Ciencias Naturales, Quito, Ecuador

MNHN = Muséum national d'Histoire naturelle, Paris, France

MNHU = Museum für Naturkunde, Leibniz-Institut für Evolutions- und Biodiversitätsforschung an der Humboldt Universität, Berlin, Germany

MUSM = Museo de Historia Natural, Universidad Nacional Mayor de San Marcos, Lima, Peru

MZSP = Museu de Zoologia, Universidade de São Paulo, São Paulo, Brazil

MZUJ = Zoological Museum, Jagellonian University, Krakow, Poland.

NHMUK = Natural History Museum, London, UK (formerly BMNH)

$\mathrm{NMBE}=$ Naturhistorisches Museum der Bürgergemeinde Bern, Bern, Switzerland

RFC $=$ Romero Family collection, Maracay, Venezuela

USNM = National Museum of Natural History, Smithsonian Institution, Washington, DC, USA

ZSM = Zoologische Staatssammlung München, München, Germany

ZUEC = Museu de Zoologia da Universidade Estadual de Campinas, Campinas, Brazil 


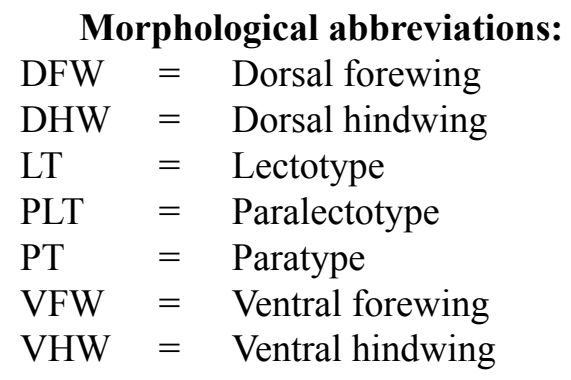

Appropriate type labels will be added to all types designated here.

\section{Molecular study}

DNA extraction methods, PCR conditions and primers used for amplification of cytochrome c oxidase I (COI) largely follow Nakahara et al. (2018a), except for several pairs of primers designed to amplify smaller fragments of COI; information on all primers used in this study is provided in Table 2. Sequences generated through this study were uploaded to GenBank and sequence voucher information is provided in Table 3. The dataset (646 bp), including 28 ingroup taxa representing eight species and five outgroup taxa (see Table 3), was aligned using MUSCLE (ver. 3.8.425) (Edgar 2004) in Geneious ver. 11.1.5 (Biomatters Ltd.), the best-fit model of nucleotide evolution (TIM2+F+I+G4) was obtained using ModelFinder (Kalyaanamoorthy et al. 2017), and the likelihood tree with the highest log-likelihood score given the aforementioned dataset was inferred by conducting Nearest Neighbor Interchange (NNI) search strategy based on the twenty best initial trees in IQ-TREE ver. 1.6.9 (Nguyen et al. 2015). The tree was rooted with Pindis squamistriga R. Felder, 1869 based on the much larger dataset including $>2000$ euptychiine individuals representing $>420$ euptychiine species (unpubl. data). Branch support was calculated using ultrafast bootstrap (UFBoot) with 1000 replications (Hoang et al. 2018), in addition to assessments of node support through 1000 replications of the Shimodaira Hasegawa approximate Likelihood Ratio Test (SH-aLRT) (Guindon et al. 2010). The genetic distances among species of Zischkaia presented in Table 4 were calculated by the Tamura-Nei distance model based on the aforementioned COI alignment in Geneious ver. 11.1.5 (Biomatters Ltd.).

\section{Databasing and georeferencing}

Label data of examined specimens were entered into a Microsoft Access database, which was also used to generate data for the 'Examined specimens' sections. If coordinate data were not provided on the label, we georeferenced the locality information and coordinates are provided in square brackets in the relevant section. For historical type specimens, information on the labels was written verbatim and information for each label is separated by double forward slashes ' $/ /$ '; if additional information is found on the other side of the label, a single forward slash ' $\%$ is used to reflect this information. Square brackets '[]' are used to enclose supplementary or inferred information. 


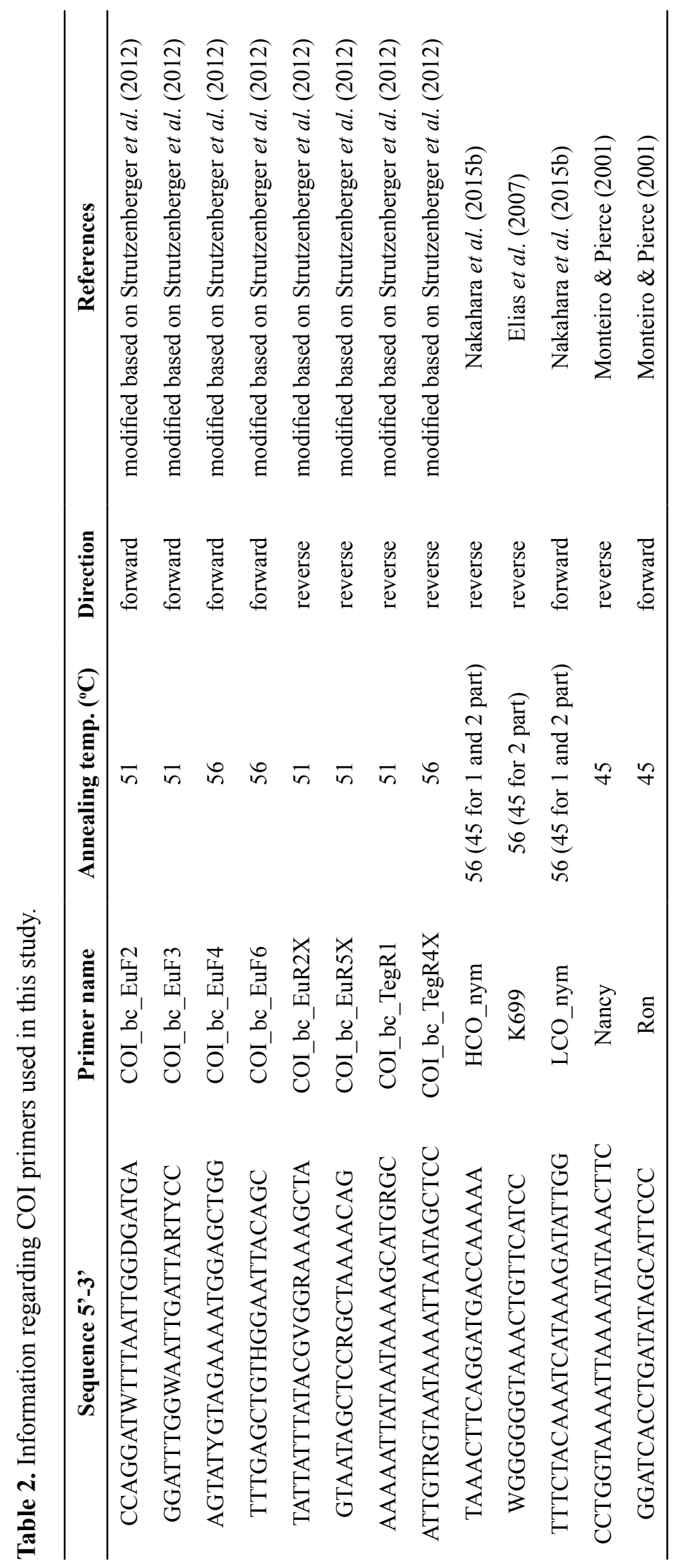


Table 3. GenBank accession numbers for specimens used for molecular analysis in this study.

\begin{tabular}{|c|c|c|c|}
\hline Voucher code & Genus & Species & GenBank Acc. No. \\
\hline LEP-68763 & Zischkaia & josti & MK880122 \\
\hline BC-DZ-227 & Zischkaia & warreni & MK880099 \\
\hline BC-DZ-231 & Zischkaia & chullachaki & MK880097 \\
\hline BC-DZ-247 & Zischkaia & pacarus & MK880098 \\
\hline LEP-37388 & Zischkaia & abanico & MK880100 \\
\hline BC-DZ-226 & Zischkaia & warreni & MK880101 \\
\hline BC-DZ-249 & Zischkaia & mielkeorum & MK880102 \\
\hline CP14-02 & Zischkaia & pacarus & GQ864819 \\
\hline BC-DZ-246 & Zischkaia & pacarus & MK880103 \\
\hline MGCL-LOAN-266 & Zischkaia & chullachaki & MK880109 \\
\hline LEP-64863 & Zischkaia & arenisca & MK880110 \\
\hline LEP-64860 & Zischkaia & arenisca & MK880111 \\
\hline LEP-64859 & Zischkaia & arenisca & MK880112 \\
\hline LEP-64862 & Zischkaia & arenisca & MK880113 \\
\hline LEP-64857 & Zischkaia & arenisca & MK880114 \\
\hline LEP-64861 & Zischkaia & arenisca & MK880115 \\
\hline LEP-64858 & Zischkaia & arenisca & MK880116 \\
\hline LEP-64864 & Zischkaia & arenisca & MK880116 \\
\hline MGCL-LOAN-518 & Zischkaia & pacarus & MK880104 \\
\hline BC-DZ-229 & Zischkaia & chullachaki & MK880105 \\
\hline BC-DZ-232 & Zischkaia & chullachaki & MK880106 \\
\hline LEP-08939 & Zischkaia & arenophilia & MK880107 \\
\hline BC-DZ-230 & Zischkaia & chullachaki & MK880108 \\
\hline MGCL-LOAN-548 & Zischkaia & saundersii & MK880118 \\
\hline MGCL-LOAN-541 & Zischkaia & saundersii & MK880119 \\
\hline LEP-18704 & Zischkaia & josti & MK880120 \\
\hline BC-DZ-225 & Zischkaia & mielkeorum & MK880123 \\
\hline BC-DZ-248 & Zischkaia & mielkeorum & MK880122 \\
\hline NW165-5 & Pindis & squamistriga & GQ357211 \\
\hline СР01-23 & Amphidecta & clio & DQ338810 \\
\hline СР02-48 & Splendeuptychia & boliviensis & GU205866 \\
\hline СР02-44 & Splendeuptychia & itonis & DQ338811 \\
\hline CP12-06 & Pharneuptychia & innocentia & DQ338808 \\
\hline
\end{tabular}




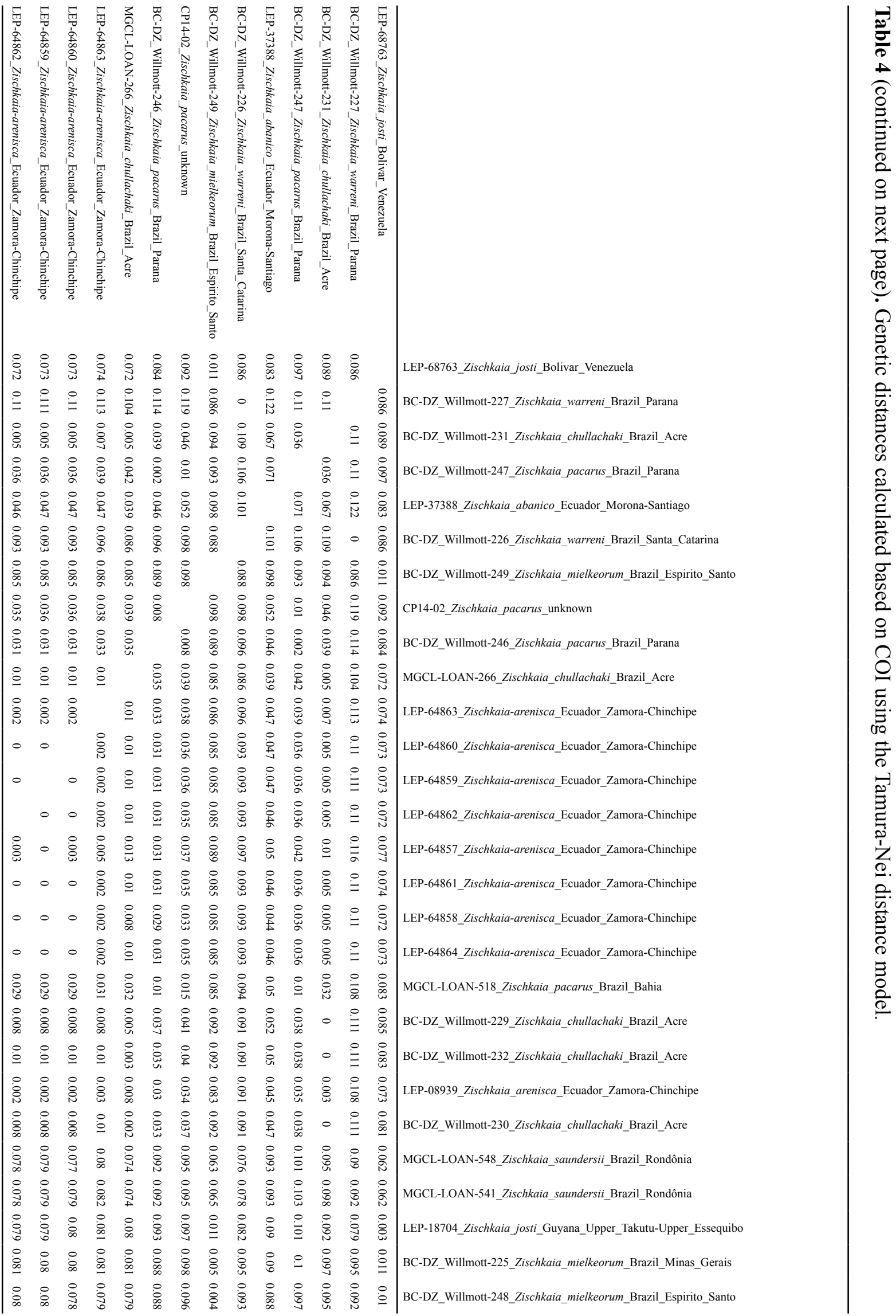




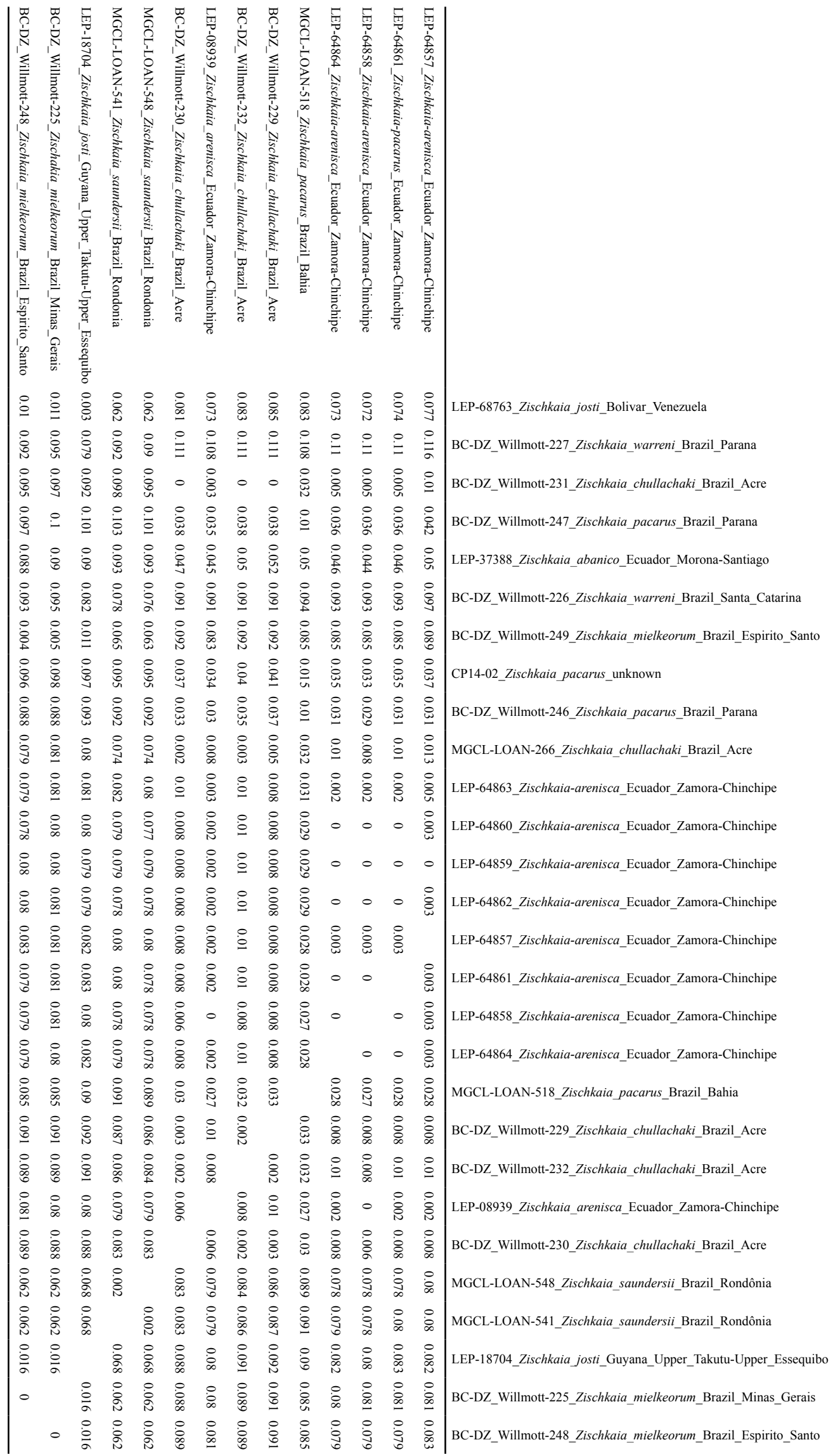




\section{Results}

Order Lepidoptera Linnaeus, 1758

Superfamily Papilionoidea Latreille, [1802]

Family Nymphalidae Rafinesque, 1815

Subfamily Satyrinae Boisduval, 1833

Tribe Satyrini Boisduval, 1833

Subtribe Euptychiina Reuter, 1896

Genus Zischkaia Forster, 1964

Zischkaia Forster, 1964: 116.

\section{Type species}

Euptychia fumata Butler, 1867: 109, pl. 12, fig. 14 (by original designation).

\section{Systematics}

Zischkaia is a member of a clade consisting of several species of Splendeuptychia Forster, 1964 (e.g., S. itonis (Hewitson, 1862), S. clementia (Butler, 1877)), Amphidecta Butler, 1867 and Rareuptychia Forster, 1964, based on the aforementioned large dataset including $>2000$ individuals representing $>420$ species (unpubl. data). Although Zischkaia was not included in the analysis of Espeland et al. (2019), the clade containing these related species (the "Amphidecta clade") was well supported based on hybrid enrichment data incorporating 368 loci (Espeland et al. 2019). The "Amphidecta clade" is sister to a large clade including some major euptychiine clades, such as the "Pareuptychia clade", "Taygetis clade" and "Splendeuptychia clade" (all sensu Peña et al. 2010), but the support for this relationship is low. Our molecular data based on the COI barcoding region strongly support Zischkaia itself as monophyletic (Fig. 1; SH-aLRT/UFBoot $=98.7 / 100$ ), with the removal by Freitas et al. $(2018)$

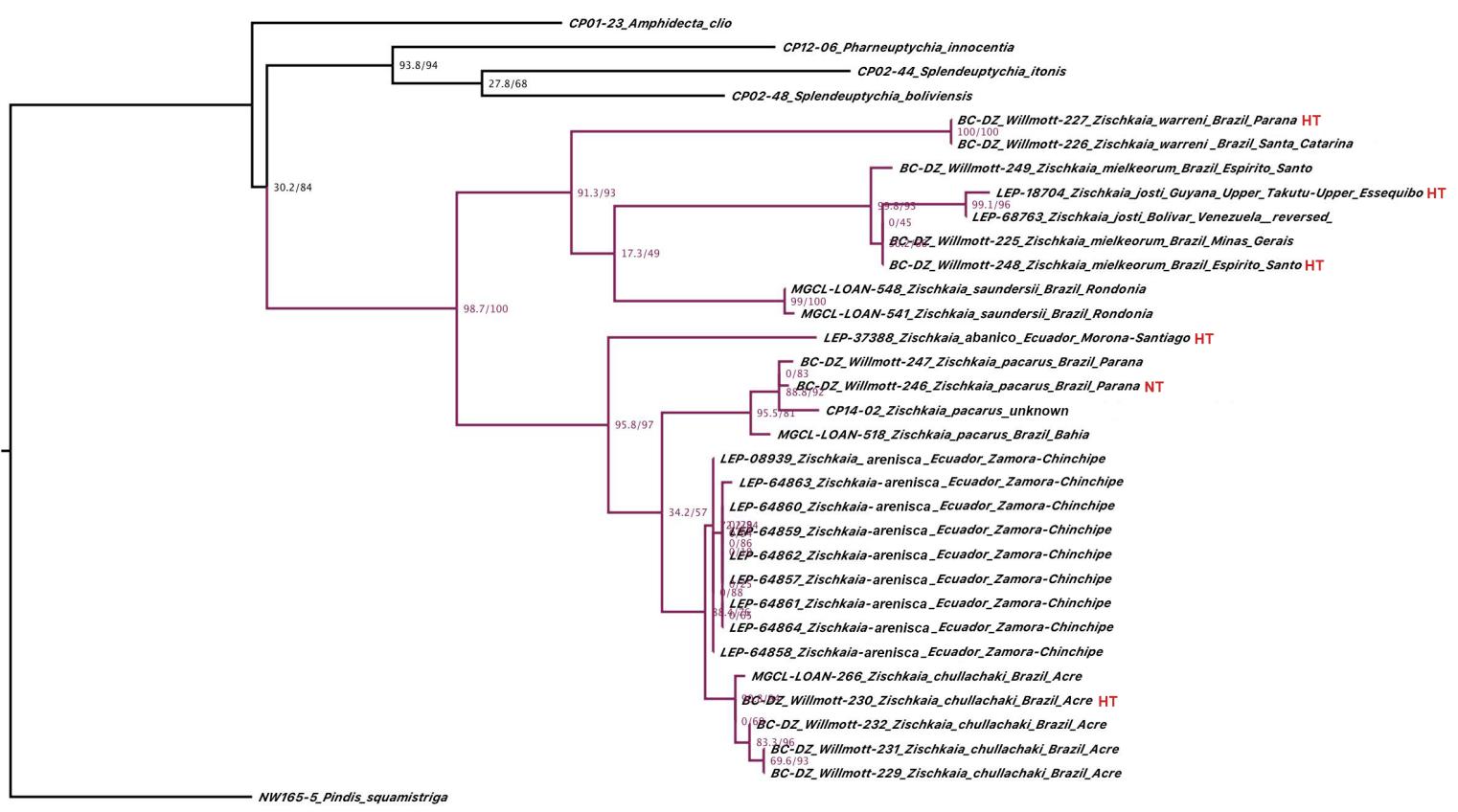

Fig. 1. Likelihood tree with the best log-likelihood score $(-\mathrm{LnL}=-2536.1613)$ given our data based on DNA 'barcodes', depicting Zischkaia as a well-supported clade. Support values are represented by SHaLRT/UF Bootstrap. Abbreviations: HT = Holotype; NT = Neotype. 
of Euptychia mima Butler, 1867 to Nhambikuara, a genus in the "Pareuptychia clade". Zischkaia can be divided into two moderate to well-supported clades based on our molecular data (Fig. 1; SH-aLRT/ UFBoot $=95.8 / 97 ; 91.3 / 93$ ), which are also diagnosable by several morphological characters discussed below under the 'Diagnosis' section. Despite the morphological differences between the two clades, which are also highly supported based on molecular data, the overall wing patterns and habitats appear to be rather similar among species in both of these clades. Considering that generic names should ideally be informative for the recognition of monophyletic groups of similar appearing species, in addition to having potential value in predicting unknown biological traits, we here treat Zischkaia as representing both clades rather than treating them as distinct genera. The morphological diversity within Zischkaia, such as the presence or absence of wing androconial scales, is also seen within other euptychiine genera of similar species diversity, such as Taygetina Forster, 1964.

\section{Diagnosis}

Species of Zischkaia can be distinguished from all other genera of Euptychiina by the combination of the following characters: 1) absence of ocelli on the DFW, DHW and VFW (also true of some other euptychiines); 2) five or six ocelli on the VHW from $\mathrm{Sc}+\mathrm{R}_{1}$ or $\mathrm{M}_{1}$ to $2 \mathrm{~A}$ with the white pupils (often diffuse scales rather than a single spot) displaced distally from the center (Splendeuptychia doxes (Godart, [1824]) and relatives possess a superficially similar pupil, but it is displaced basally instead of distally); 3) VFW with submedian line restricted to discal cell or absent (also true of a number of other euptychiine genera); 4) inter-segmental membrane between seventh and eighth sternites not pleated, but folded posteriorly of ostium bursae with its sclerotized region forming a 'scoop-like' structure below lamella antevaginalis (projection more apparent in species of the "pacarus clade"). This form of intersegmental membrane is rather unique among euptychiines, which often have this membrane pleated and expandable, although some species in the genus Euptychia Hübner, 1818 are somewhat similar in this respect.

Two clades are recognized in Zischkaia, which we call the "pacarus clade" and the "saundersii clade"; the former can be distinguished from the latter by: 1) presence of androconial scales on DFW of males (absent in "saundersii clade") (Figs 2-3); 2) presence of a 'tusk'-like projection (Fig. 4A) from the posterior region of the tegumen above the uncus (the projection of the tegumen appears as a 'bulb' in the "saundersii clade" (Fig. 5A)); 3) uncus that is narrow and long, somewhat curving down, terminating in a small 'bulb' (rather than being straight and broad as in the "saundersii clade"); 4) brachia curved dorsally (rather than straight as in the "saundersii clade"); 5) valva being rather short in lateral view, with the apical point not extending beyond that of the uncus (the apical point extends beyond that of the uncus in the "saundersii clade"); 6) tip of the anterior projection of the saccus extending further than the tegumen in lateral view (the tip of the anterior projection of the saccus does not extend beyond the tegumen in lateral view in the "saundersii clade"); 7) fultura inferior (i.e., juxta) appearing as a thin strip in posterior view (Fig. 8A) (it appears as a well-developed plate in posterior view in the "saundersii clade" (Fig. 8B)); 8) median region of the ductus bursae with a well-developed sclerotized half-ring (Fig. 6A) (absent in the "saundersii clade" (Fig. 7A), or very reduced as in Z. saundersii and Z. josti sp. nov.).

The diagnostic characters provided above for the "pacarus clade" can be used to separate all species in this clade from species in the "saundersii clade", and vice-versa. Therefore, species diagnoses focus on comparing similar species within the respective clade. Note that females of Z. amalda (Weymer, 1911), Z. argyrosflecha Nakahara, L. Miller \& Huertas, sp. nov., Z. abanico Nakahara \& Petit, sp. nov. and $Z$. arctoa Nakahara, sp. nov. are still unknown or unrecognized, thus the diagnostic characters provided for females of related species might not be applicable to these four species, and discovery of female specimens of these taxa would be extremely valuable. Similarly, the male is unknown or unrecognized for Z. josti Nakahara \& Kleckner, sp. nov. 

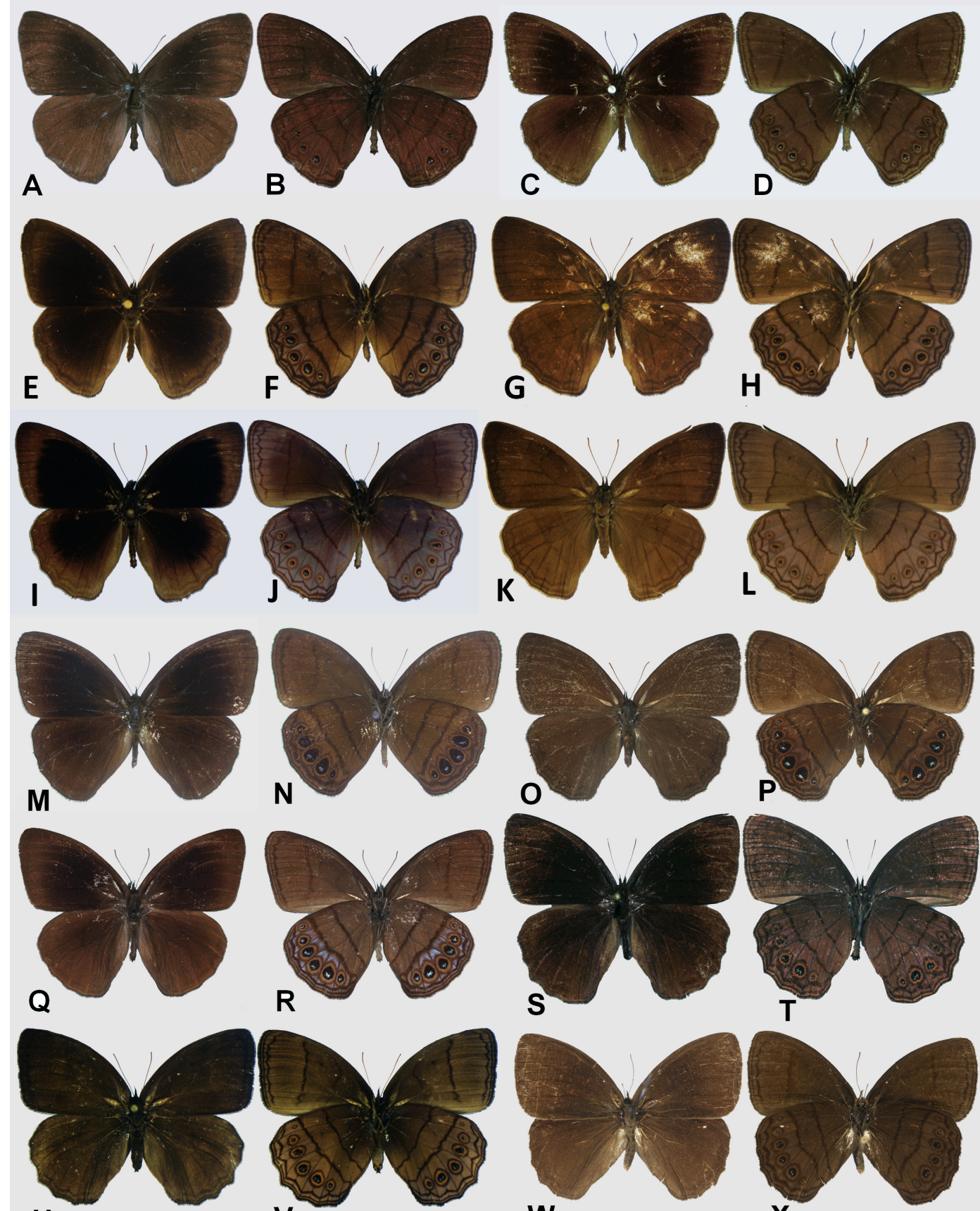

$\mathbf{U}$
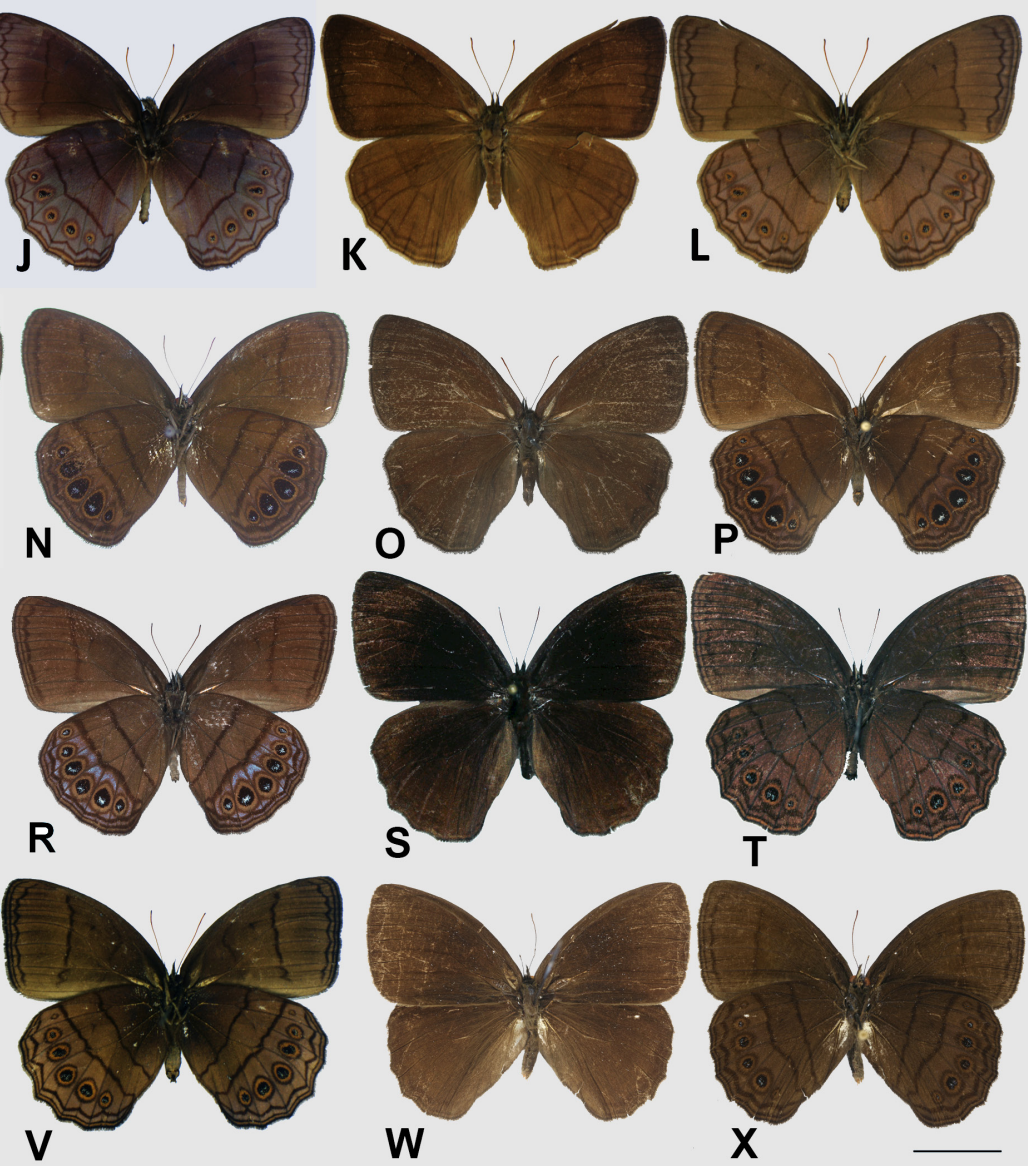

$\mathrm{T}$

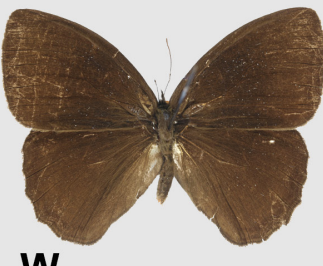

W

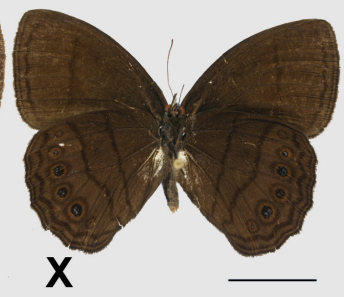

Fig. 2. Zischkaia "pacarus clade", wing plate. A-B. Z. amalda (Weymer, 1911), lectotype, đ̂, dorsal and ventral views. C-D. Z. arctoa Nakahara, sp. nov., paratype, $\sigma^{\lambda}$ (in RFC, collected in 1975), dorsal and ventral views. E-F. Z. chullachaki Nakahara \& Zacca, sp. nov., holotype, Ô, dorsal and ventral views. G-H. Z. chullachaki sp. nov., paratype, ㅇ (DZ 36. 508), dorsal and ventral views. I-J. Z. baku Zacca, Dolibaina \& Dias, sp. nov., holotype, $\hat{\jmath}$, dorsal and ventral views. K-L. Z. baku sp. nov., paratype, + (DZ 36. 404), dorsal and ventral views. M-N. Z. arenisca Nakahara, Willmott \& Hall,

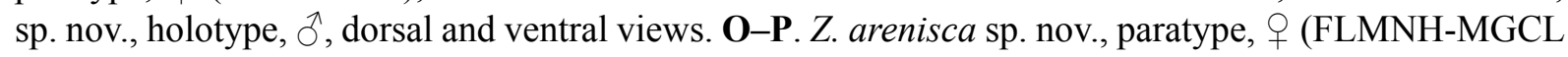
297320), dorsal and ventral views. Q-R. Z. argyrosflecha Nakahara, L. Miller \& Huertas, sp. nov.,

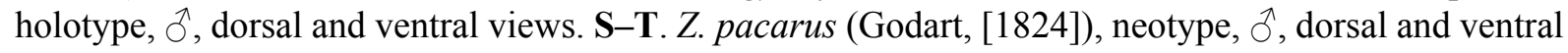
views. U-V. Z. pacarus,, (DZ 36. 909), dorsal and ventral views. W-X. Z. abanico Nakahara \& Petit, sp. nov., holotype, $\widehat{\jmath}$, dorsal and ventral views. Scale bar: $1 \mathrm{~cm}$. 


\section{History of classification}

Butler (1867a) was the first to propose a systematic classification for Zischkaia. In his monograph of Euptychia (then used as a catch-all genus to include most euptychiine species), Butler divided the genus into seven groups (Division I to VII), and Division VI was the group relevant to Zischkaia. This division included E. saundersii Butler, 1867, E. mima Butler, 1867, E. fumata nomen nudum, E. pacarus (Godart, [1824]) and E. insignis Butler, 1867. The following diagnosis was given for Butler's Division VI: "Upper surfaces brown, without marks; ventral forewings generally unmarked; [ventral] hindwings frequently with oval-shaped black ocelli, pupilled with silvery spots". Subsequently, Butler (1877) proposed the "E. pacarus group" and included E. saundersii, E. mima, E. fumata Butler, 1867, E. pacarus, E. insignis,

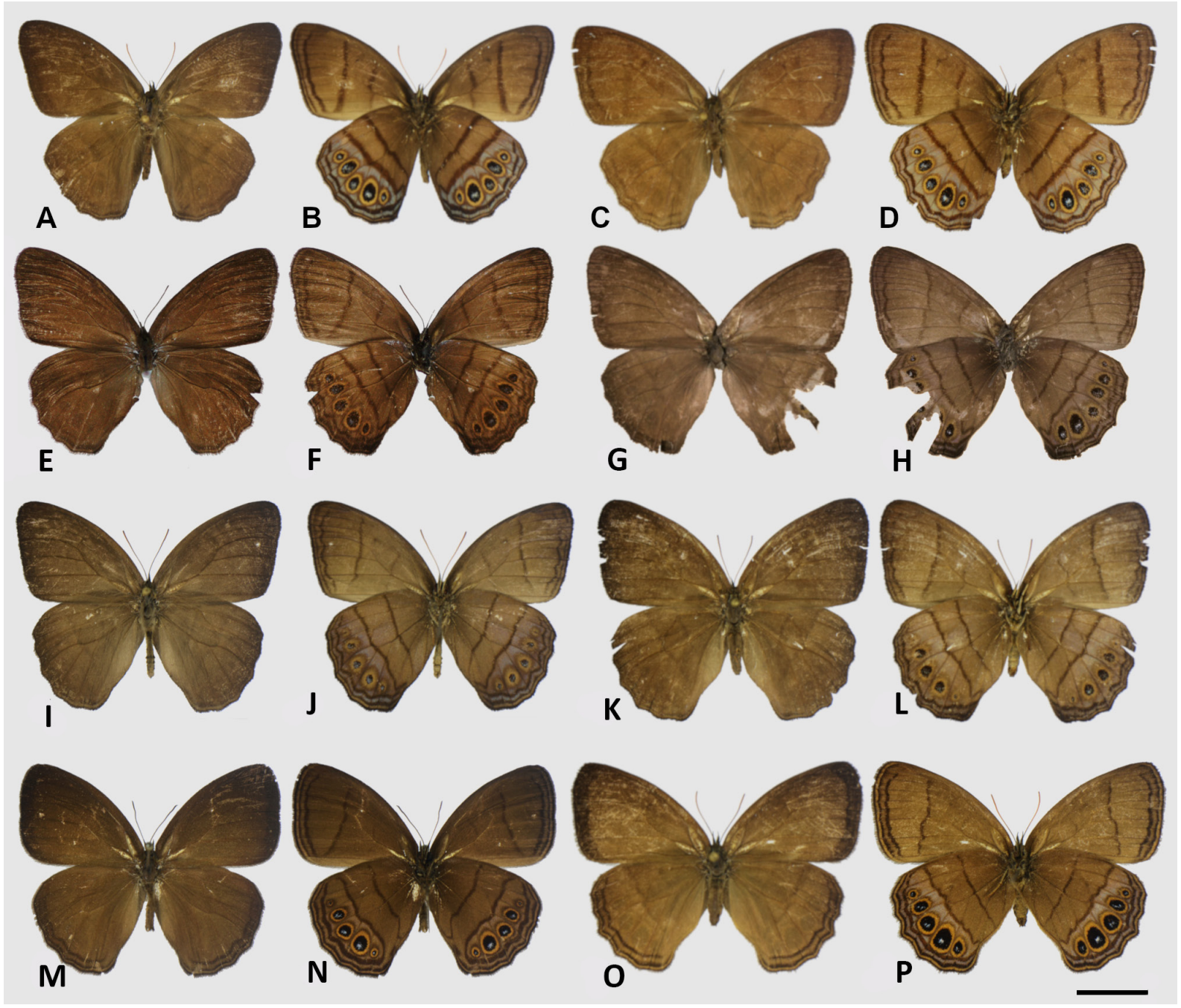

Fig. 3. Zischkaia "saundersii clade", wing plate. A-B. Z. saundersii (Butler, 1867), § (DZ 37. 029), dorsal and ventral views. C-D. Z. saundersii, $q$ (DZ 36. 969), dorsal and ventral views. E-F. Z. josti Nakahara \& Kleckner, sp. nov., holotype,, , dorsal and ventral views. G-H. Z. josti sp. nov., paratype, $q$ (USNM ENT 00233844), dorsal and ventral views. I-J. Z. mielkeorum Dolibaina, Dias \& Zacca, sp. nov., holotype, $\widehat{\jmath}$, dorsal and ventral views. K-L. Z. mielkeorum sp. nov., paratype, + (DZ 36. 618), dorsal and ventral views. M-N. Z. warreni Dias, Zacca \& Dolibaina, sp. nov., holotype, ${ }^{\lambda}$, dorsal and ventral views. O-P. Z. warreni sp. nov., paratype, $q$ (DZ 36. 508), dorsal and ventral views. Scale bar: $1 \mathrm{~cm}$. 


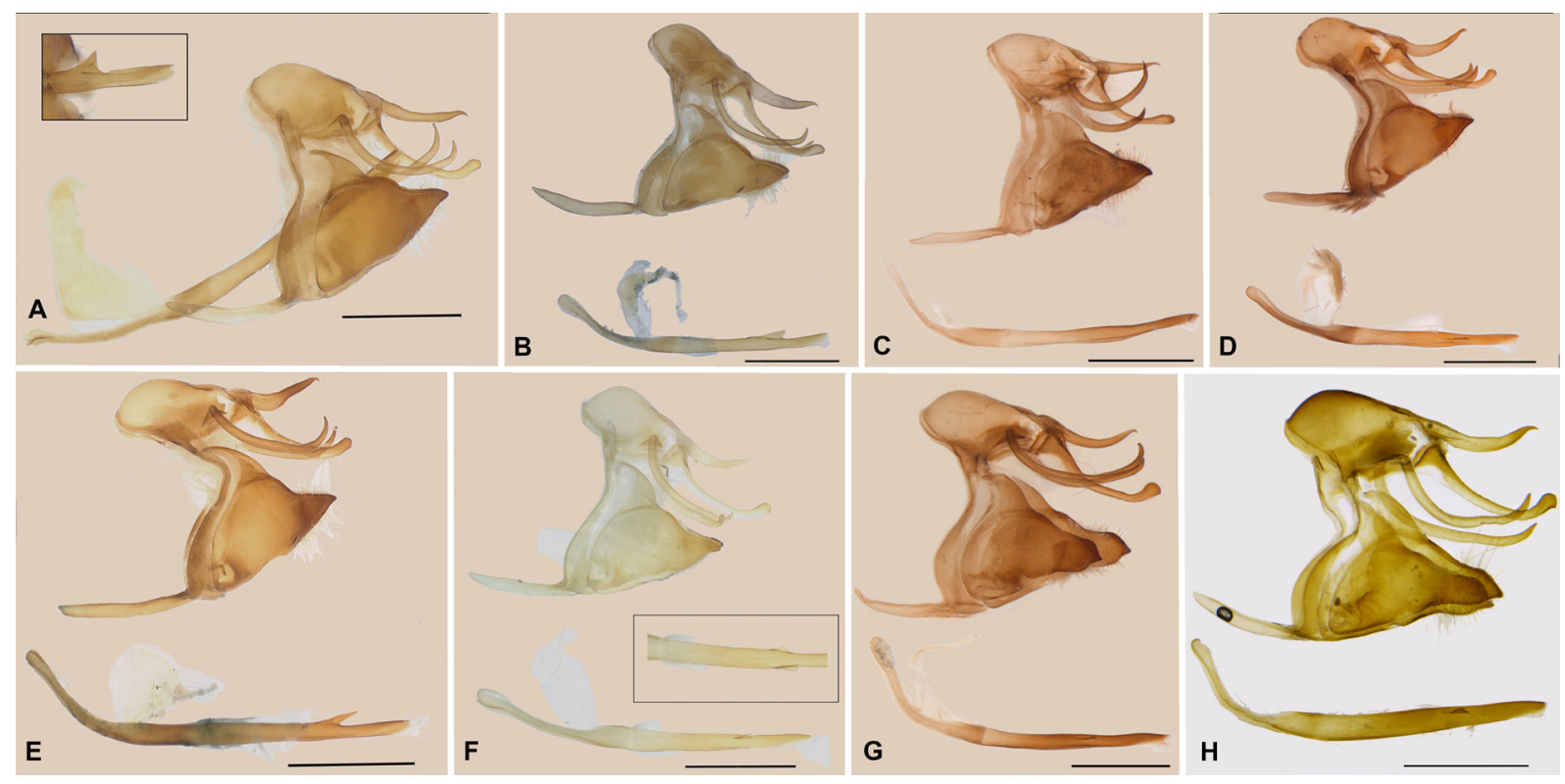

Fig. 4. Zischkaia "pacarus clade", male genitalia. A. Z. amalda (Weymer, 1911), lectotype, ภ̂, lateral view, with phallus separated (winglet on aedeagus shown inside rectangle) (Genitalic vial: SN-1721). B. Z. arctoa Nakahara, sp. nov., O, lateral view, with phallus separated (Genitalic vial: SN-17-9). C. Z. chullachaki Nakahara \& Zacca, sp. nov., Ô, lateral view, with phallus separated (Genitalic vial: DZ 21. 235). D. Z. baku Zacca, Dolibaina \& Dias, sp. nov., ô, lateral view, with phallus separated (Genitalic vial: DZ 5. 573). E. Z. arenisca Nakahara, Willmott \& Hall, sp. nov., $\hat{O}^{2}$, lateral view, with phallus separated (Genitalic vial: SN-17-16). F. Z. argyrosflecha Nakahara, L. Miller \& Huertas, sp. nov. Ō, lateral view, with phallus separated (two winglets on aedeagus shown inside rectangle) (Genitalic vial: M-9142 Ô, Lee D. Miller). G. Z. pacarus (Godart, [1824]), ô, lateral view, with phallus separated (Genitalic vial: DZ 5. 578). H. Z. abanico Nakahara \& Petit, sp. nov., $\sigma^{\lambda}$, lateral view, with phallus separated (Genitalic vial: 575/19.07.2017, J. Lorenc-Brudecka, MZUJ).
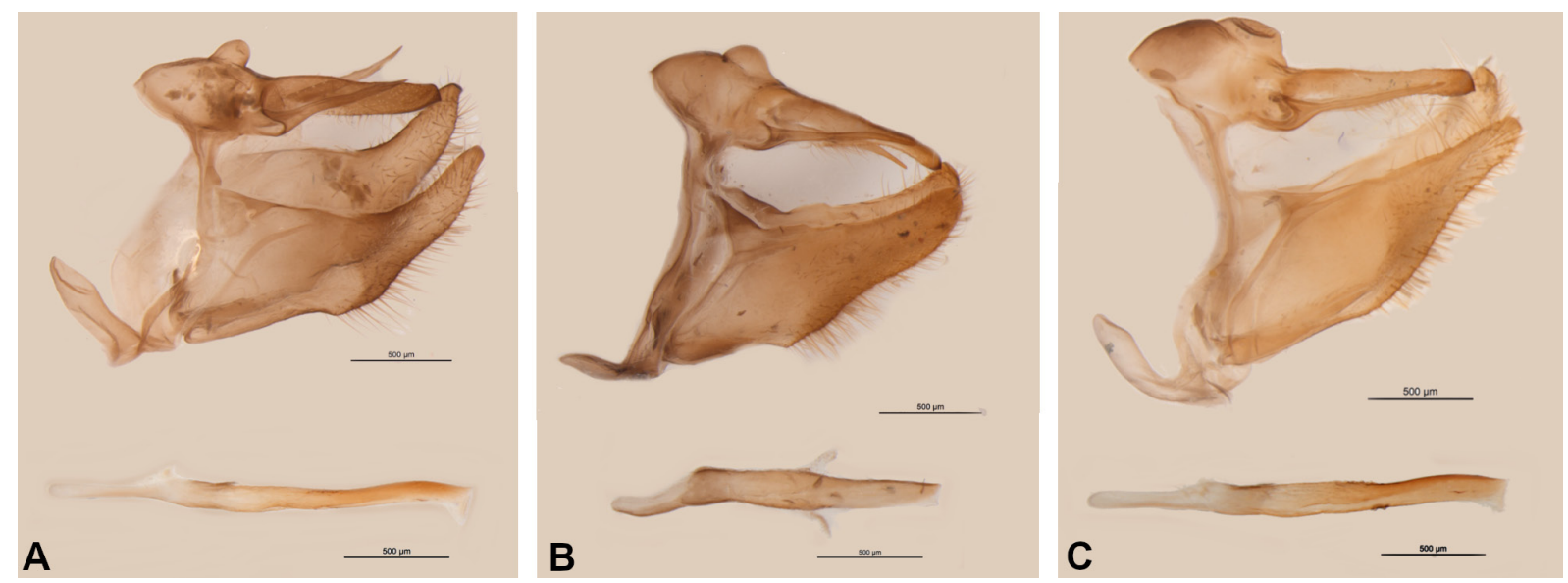

Fig. 5. Zischkaia "saundersii clade", male genitalia. A. Z. saundersii (Butler, 1867), $\widehat{\jmath}$, lateral view, with phallus separated (Genitalic vial: DZ 21. 221). B. Z. mielkeorum Dolibaina, Dias \& Zacca, sp. nov., Ō, lateral view, with phallus separated (Genitalic vial: DZ 21. 200). C. Z. warreni Dias, Zacca \& Dolibaina, sp. nov., $\widehat{O}$, lateral view, with phallus separated (Genitalic vial DZ 21. 214). 
A

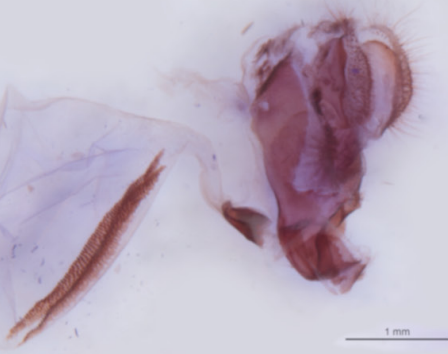

B
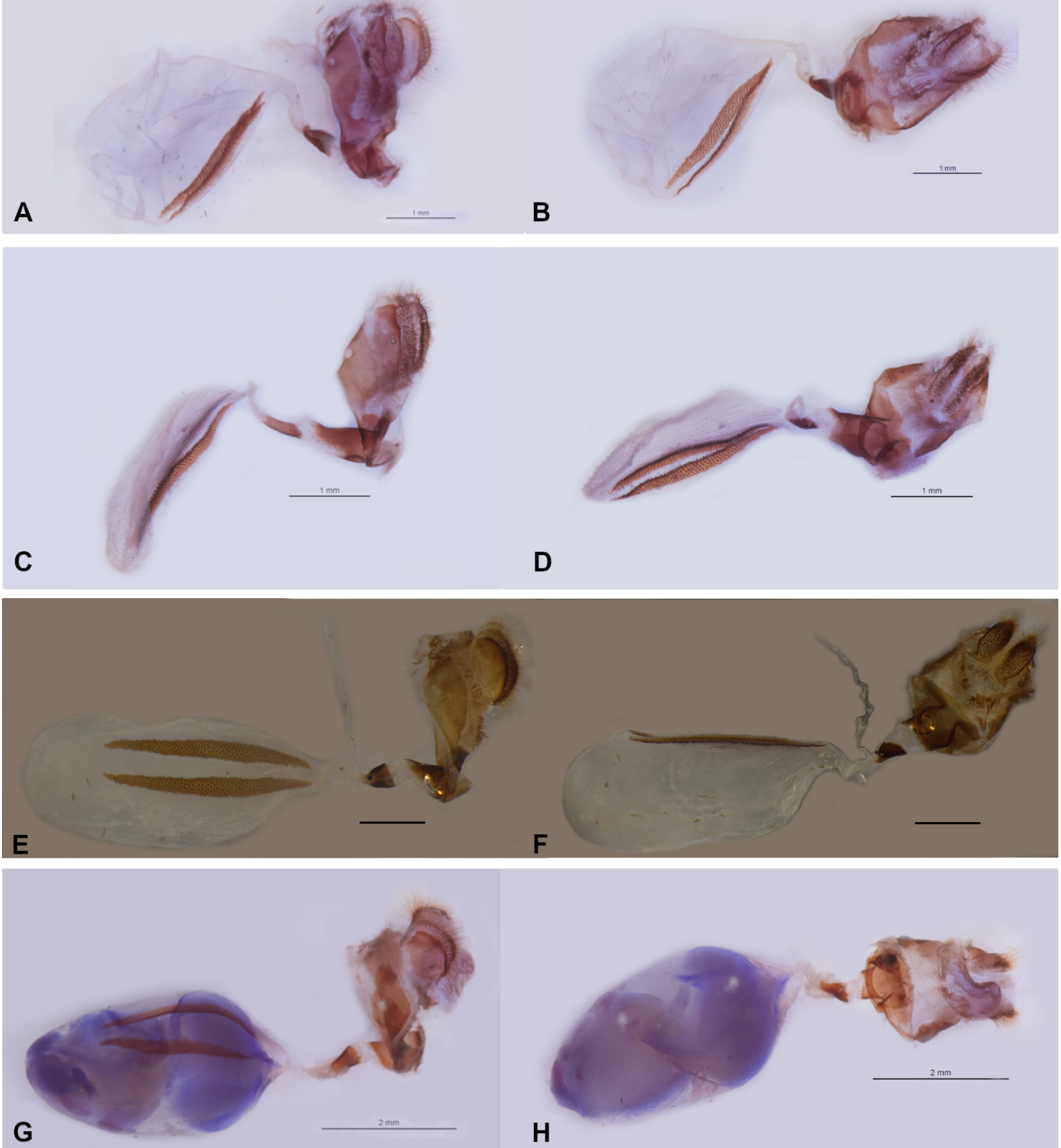

Fig. 6. Zischkaia "pacarus clade", female genitalia. A-B. Z. chullachaki Nakahara \& Zacca, sp. nov.,, , lateral and ventral views (Genitalic vial DZ 36. 508). C-D. Z. baku Zacca, Dolibaina \& Dias, sp. nov.,, , lateral and ventral views (Genitalic vial: DZ 5. 571). E-F. Z. arenisca Nakahara, Willmott \& Hall, sp. nov.,, , lateral and ventral views (Genitalic vial: SN-17-174). G-H. Z. pacarus (Godart, [1824]),, , lateral and ventral views (Genitalic vial: DZ 36. 731). 

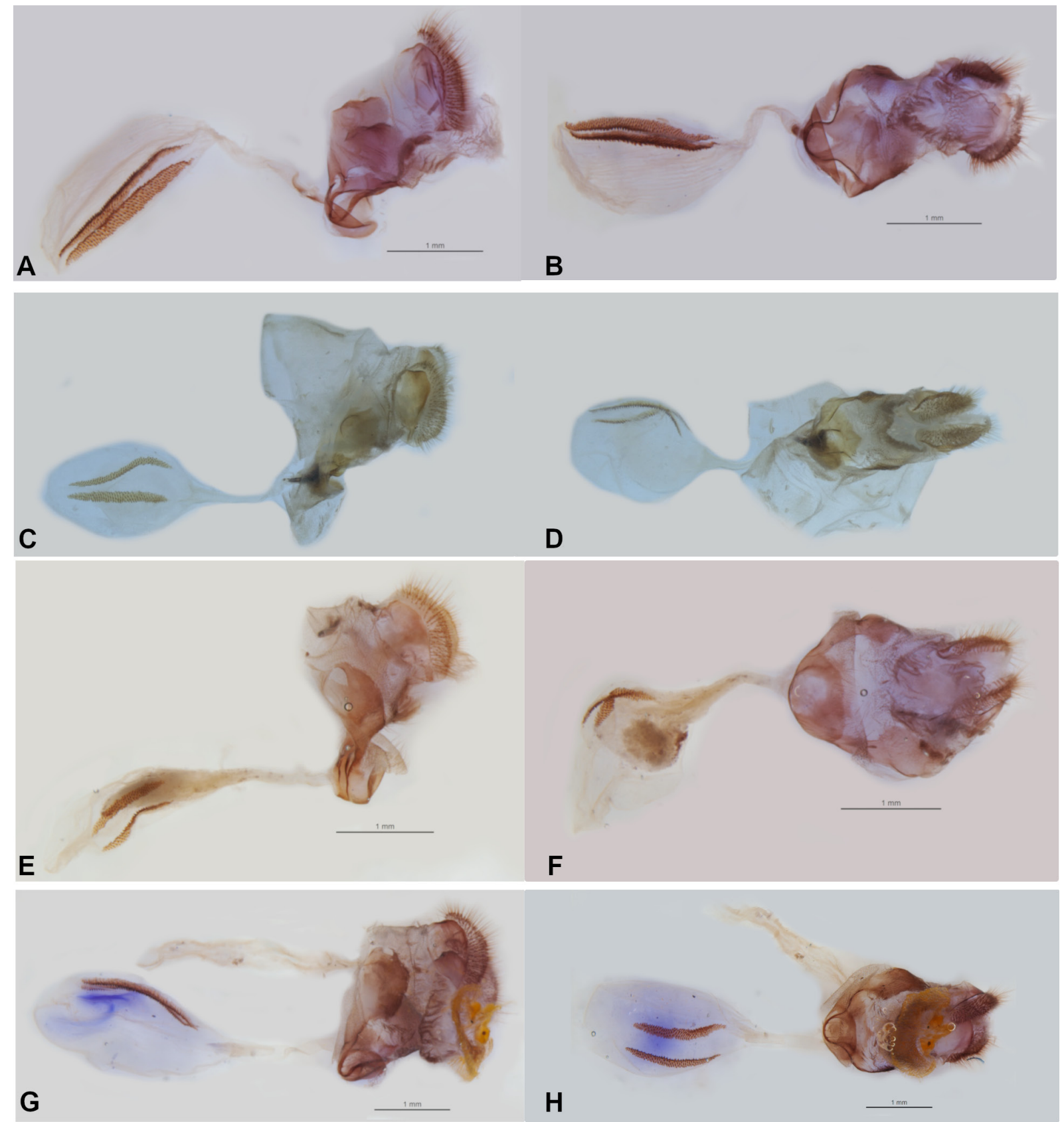

Fig. 7. Zischkaia "saundersii clade", female genitalia. A-B. Z. saundersii (Butler, 1867),, , lateral and ventral views (Genitalic vial: DZ 36. 969). C-D. Z. josti Nakahara \& Kleckner, sp. nov., + , lateral and ventral views (Genitalic vial: 2018-002, D.J. Harvey). E-F. Z. mielkeorum Dolibaina, Dias \& Zacca, sp. nov., + , lateral and ventral views (Genitalic vial: DZ 36. 688). G-H. Z. warreni Dias, Zacca \& Dolibaina, sp. nov.,, , lateral and ventral views (Genitalic vial: DZ 36. 731). 
E. peculiaris Butler, 1874 and E. erichtho Butler, 1867. The last taxon was described and placed in Division VII in Butler's (1867a) classification, but the name is currently regarded as a junior subjective synonym of Neonympha antonina C. Felder \& R. Felder, 1867 (now placed in Erichthodes Forster, 1964) (Lamas 2004). Weymer (1911) proposed a similar group, named the "pacarus group", in which he included E. saundersii, E. mima, E. fumata, E. pacarus, E. peculiaris, E. insignis, E. erichtho and his E. amalda. Forster (1964) erected the genus Zischkaia by designating Euptychia fumata as the type species and stated: "In this newly erected genus I include some very similar in appearance, large, dorsally unicolorous brown species, which regarding the anatomical structure of the male Genitalia (figs 123125) correspond well with one another and are differentiated from all other 'Euptychia' species by the long, slender subunci and unique, unpaired outgrowths of the tegumen, which are located dorsally over the uncus". Based on these diagnostic characters, in addition to the type species, Forster (1964) recognized $Z$. amalda and $Z$. saundersii in the genus, and figured the male genitalia for all three species. Lamas (2004) included four species, namely Z. amalda, Z. pacarus, Z. saundersii, and Z. mima, in addition to recognizing one undescribed species (described here as $Z$. arenisca sp. nov.). The checklist of Lamas (2004) also treated Euptychia fumata (described by Butler 1867b: 109) as a junior subjective synomym of E. pacarus, and E. fumata (cited by Butler 1867a: 501) as a nomen nudum. Euptychia mima Butler, 1867, a taxon formerly placed in Zischkaia, was recently made the type species of Nhambikuara by Freitas et al. (2018).

\section{Distribution and natural history}

All confirmed records for Zischkaia are exclusively east of the Andes (but see also discussion under Z. abanico sp. nov.), where species are found from sea level up to about $1600 \mathrm{~m}$. The known distributions of a number of species are highly restricted, with typically only a single species occurring in a particular locality, although label data suggest local sympatry between $Z$. warreni Dias, Zacca \& Dolibaina, sp. nov. and Z. pacarus in southeastern Brazil, and Zischkaia chullachaki Nakahara \& Zacca, sp. nov. and $Z$. saundersii in southeastern Peru. Perhaps notably, these two cases concern species in the two different clades, with no known cases of sympatry in members of the same clade. There are a few published observations on the behavior of Zischkaia, which are typically found in forest in close proximity to patches of bamboo (Poaceae: Bambusoideae), their likely hostplant; Brown (1992) reported the larvae of Z. pacarus using "bamboo", as did Freitas in Beccaloni et al. (2008) (see also natural history notes under Z. arenisca sp. nov.).

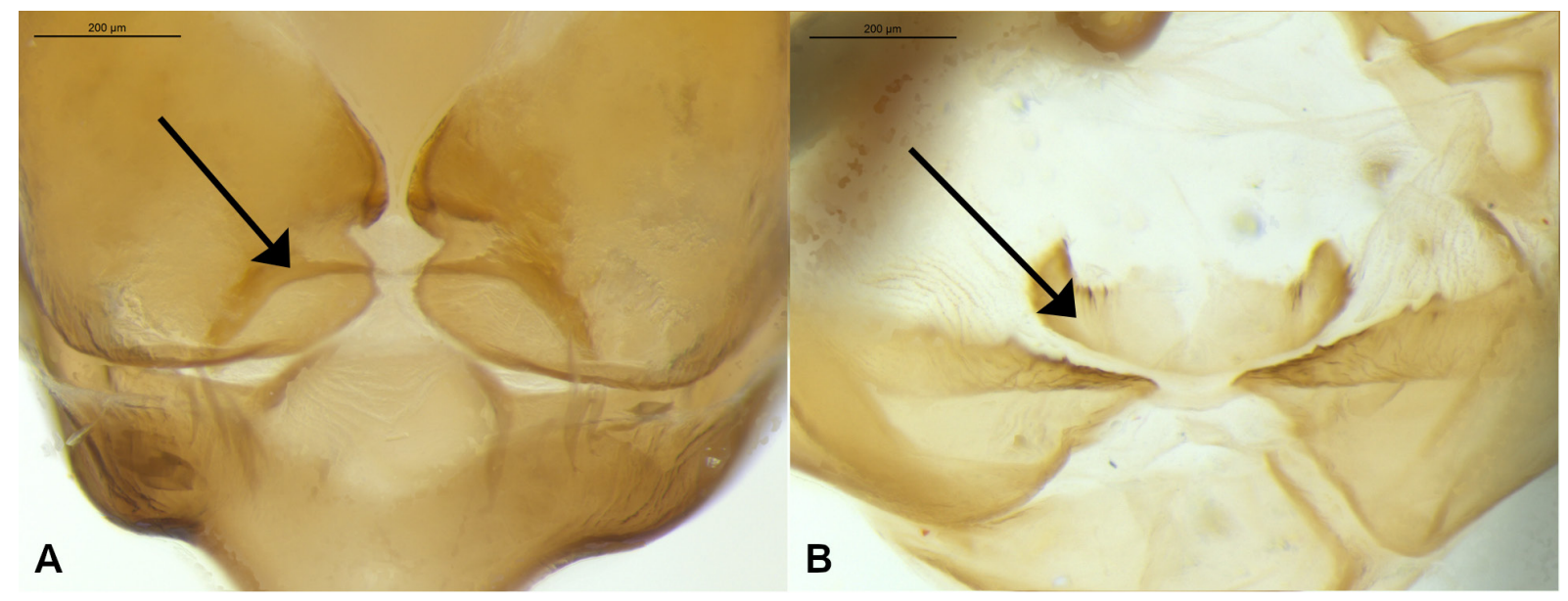

Fig. 8. Fultura inferior (i.e., juxta). A. Zischkaia pacarus (Godart, [1824]) (DZ 5. 578), in ventral view. B. Z. saundersii (Butler, 1867) (DZ 5. 580), in posterior view. 


\section{Species accounts}

Zischkaia Forster, 1964

amalda (Weymer, 1911)

arctoa Nakahara, sp. nov.

chullachaki Nakahara \& Zacca, sp. nov.

baku Zacca, Dolibaina \& Dias, sp. nov.

arenisca Nakahara, Willmott \& Hall, sp. nov.

argyrosflecha Nakahara, L. Miller \& Huertas, sp. nov.

pacarus (Godart, [1824])

= fumata (Butler, 1867a), nom. nud.

= fumata (Butler, 1867b)

abanico Nakahara \& Petit, sp. nov.

saundersii (Butler, 1867)

josti Nakahara \& Kleckner, sp. nov.

mielkeorum Dolibaina, Dias \& Zacca, sp. nov.

warreni Dias, Zacca \& Dolibaina, sp. nov.

\section{Key to species of Zischkaia}

DFW and DHW androconial scales present in males; projection from posterior region of tegumen above uncus 'tusk'-like; uncus narrow and long, somewhat curving down, terminating in a small 'bulb' in lateral view; brachia curved dorsally; valva rather short in lateral view, apical point does not extend beyond that of uncus; tip of anterior projection of saccus extends further than tegumen in lateral view; fultura inferior (i.e., juxta) appears as a thin strip in posterior view; developed sclerotized halfring in median region of ductus bursae present.

Z. pacarus clade

DFW and DHW androconial scales absent in males; projection from posterior region of tegumen above uncus 'bulb'-like; uncus appearing straight in lateral view; valva apical point extends beyond that of uncus; tip of anterior projection of saccus does not extend beyond tegumen in lateral view; fultura inferior (i.e., juxta) appears as a developed plate in posterior view; developed sclerotized half-ring in median region of ductus bursae absent or reduced.

Z. saundersii clade

\section{"pacarus clade":}

1. VHW ocelli elongated (ocelli in VHW cells $\mathrm{M}_{2}-\mathrm{M}_{3}, \mathrm{M}_{3}-\mathrm{Cu}_{1}$, and $\mathrm{Cu}_{1}-\mathrm{Cu}_{2}$ occupying more than half space between submedian line and submarginal line)

- VHW ocelli not elongated, rather circular (ocelli in VHW cells $\mathrm{M}_{2}-\mathrm{M}_{3}, \mathrm{M}_{3}-\mathrm{Cu}_{1}$ and $\mathrm{Cu}_{1}-\mathrm{Cu}_{2}$ occupying less than half space between submedian line and submarginal line).....

2. Prominent ocellus absent in VHW Rs-M $\mathrm{M}_{1}$; lack of silverish-purple scales on the basal side of VHW ocelli (distad of submedian line); one winglet on aedeagus; aedeagus winglet obtuseangled; ventral margin of apical process of valva not concave; saccus longer than ventral margin of valva.

Z. arenisca Nakahara, Willmott \& Hall, sp. nov.

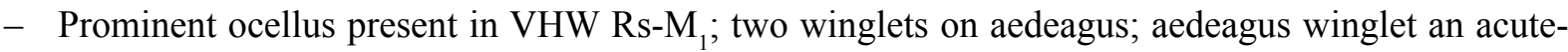
angled triangle; ventral margin of apical process of valva concave; saccus shorter than ventral margin of valva Z. argyrosflecha Nakahara, L. Miller \& Huertas, sp. nov.

3. Apical process of valva somewhat rectangular with a convex distal margin .................................. 7

- Apical process of valva somewhat subtriangular ...................................................................... 4

4. Adults small (forewing length $21-23 \mathrm{~mm}$ ); male dorsal androconial scales rather indistinct; from Andean foothills. 
- Adults large (forewing length around $25 \mathrm{~mm}$ ); male dorsal androconial scales distinct; from Amazon Basin

5. Apical process of valva somewhat elongate; ventral margin of apical process of valva convex; from Cordillera de la Costa (Venezuela).....

Z. arctoa Nakahara, sp. nov.

- Apical process of valva not elongate; ventral margin of apical process of valva almost straight or concave; from Andean foothills of Peru and Bolivia.

Z. amalda (Weymer, 1911)

6. Posterior projection of tegumen rather straight; winglet of aedeagus reduced, almost absent; lamella antevaginalis developed as a tube around ductus bursae.. Z. baku Zacca, Dolibaina \& Dias, sp. nov.

- Posterior projection of tegumen curved; winglet of aedeagus prominent, clearly visible; lamella antevaginalis not developed as a tube around ductus bursae .......................................................................... Z. chullachaki Nakahara \& Zacca, sp. nov.

7. Southern and southwestern Brazil to northeastern Argentina.

Z. pacarus (Godart, [1824])

- Tropical Andes of Colombia and Ecuador...

Z. abanico Nakahara \& Petit, sp. nov.

\section{"saundersii clade":}

1. VHW marked with prominent blue/grayish shading between submedian line and marginal line; signa long, extending almost entire length of corpus bursae. Z. saundersii (Butler, 1867)

- VHW not marked with prominent blue/grayish shading between submedian line and marginal line; signa not extending across the entire corpus bursae....

2. DHW submarginal and marginal line clearly visible; ocellus in VHW $\mathrm{M}_{1}-\mathrm{M}_{2}$ often less than half size of that in VHW $\mathrm{M}_{2}-\mathrm{M}_{3}$; median line and submarginal line fused immediately after $2 \mathrm{~A}$ in males.....

Z. warreni Dias, Zacca \& Dolibaina, sp. nov.

- DHW submarginal and marginal line almost invisible; ocellus in VHW $M_{1}-M_{2}$ often about half size (or larger) of that in VHW $\mathrm{M}_{2}-\mathrm{M}_{3}$; median line and submarginal line not fused immediately after $2 \mathrm{~A}$ in males

3. VHW ocelli in $\mathrm{M}_{1}-\mathrm{M}_{2}$ and/or $\mathrm{Cu}_{2}-2 \mathrm{~A}$ appearing as incomplete ocelli with black central area and/or pupil indistinct; small sclerotized region absent at one-third distance from ostium bursae to corpus bursae; from southeastern Brazil Z. mielkeorum Dolibaina, Dias \& Zacca, sp. nov.

- VHW ocelli in $\mathrm{M}_{1}-\mathrm{M}_{2}$ and/or CuP-2A appearing as complete ocellus with black central area and/or pupil rather distinct and clearly visible; small sclerotized region present at one-third distance from ostium bursae to corpus bursae; from Guianas. Z. josti Nakahara \& Kleckner, sp. nov.

Zischkaia amalda (Weymer, 1911)

Figs $2 \mathrm{~A}-\mathrm{B}, 4 \mathrm{~A}, 14$

Euptychia amalda Weymer, 1911: 213, pl. 48, fig. f[2] (Type Locality: Mapiri [La Paz, Bolivia]).

Euptychia amalda - Gaede 1931: 437. — D’Abrera 1988: 789.

Zischkaia amalda - Forster 1964: 116-117, fig. 124. — Lamas 2004: 223.

\section{Material examined}

Lectotype (here designated)

BOLIVIA - ${ }^{\lambda}$; “//EøTypus Nr. Euptychia amalda (Stgr)Weymer Zoologische Staatssammlung München.// amalda Weym[er].// Mapiri [La Paz, Bolivia]// 521.// 261.// Original [i.e., Type]// Genitalic vial SN-17-21 S. Nakahara//"; ZSM. 


\section{Other material $(12 \hat{\jmath})$}

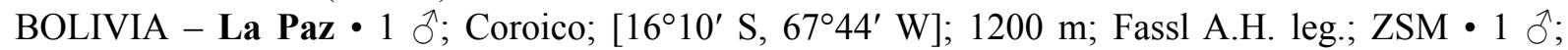

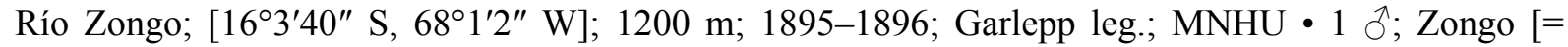
Río Zongo]; [16 ${ }^{\circ} 7^{\prime} \mathrm{S}, 68^{\circ} 2^{\prime} \mathrm{W}$ ]; Garlepp leg.; MNHU • 1 \%; same collection data as for preceding; BMNH(E)-10247952; NHMUK.

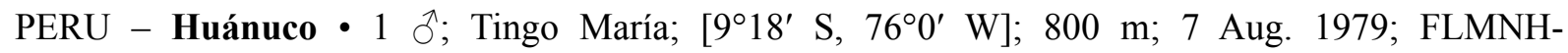

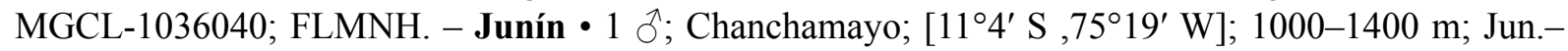
Aug. 1901; W. Hoffmanns leg.; BMNH(E)-1718080; NHMUK. - Not located • 6 ठ̋ likely from Bolivia]; USNM.

\section{Identification and taxonomy}

The male of Zischkaia amalda is distinguished from Z. baku sp. nov. and Z. chullachaki sp. nov. by the VFW submarginal line not undulating (the VFW submarginal line is undulating in Z. baku sp. nov. and $Z$. chullachaki sp. nov.), with the area of dorsal androconia rather reduced and the androconia not as prominent as in those two species. Furthermore, the male genitalia can be used to distinguish this species from Z. baku sp. nov., with the winglet of the aedeagus being developed (Fig. 4A) (reduced in Z. baku sp. nov.), and the anterior margin of the tegumen being concave in dorsal view in $Z$. amalda, whereas it is rather straight or convex in $Z$. baku sp. nov. and $Z$. chullachaki sp. nov. The male of $Z$. amalda is distinguished from that of $Z$. pacarus by the dorsal androconia being more prominent (dorsal androconia somewhat inconspicuous in $Z$. pacarus), in addition to its smaller adult size (Z. amalda: FW length 22$23 \mathrm{~mm}(\mathrm{n}=3)$; $Z$. pacarus: $25 \mathrm{~mm}(\mathrm{n}=5))$. The male genitalia of $Z$. amalda is distinguished from that of $Z$. pacarus by having a subtriangular apical process of the valva (apical process of valva somewhat rectangular with a convex distal margin in Z. pacarus). Zischkaia amalda is perhaps most similar to $Z$. arctoa sp. nov., but see the relevant section of $Z$. arctoa sp. nov. for diagnostic characters to separate these two species. Also, see the relevant section of $Z$. arenisca sp. nov. for diagnostic characters to distinguish $Z$. amalda from $Z$. arenisca sp. nov. and $Z$. chullachaki sp. nov.

Euptychia amalda was described by Weymer (1911) based on an unstated number of specimens from Mapiri, La Paz, Bolivia. The original description is accompanied by a ventral surface illustration (Weymer 1911: pl. 48, fig. f[2]), but the description and illustration alone cannot be used to confidently identify this species due to the fact that wing patterns of species of Zischkaia are often similar. The syntype male, located in the ZSM, has androconia on the DFW and DHW, which is implied in the original description ("The basal and median areas of the forewing above are velvety dark brown, the costal and distal margins lighter brown"), indicating that the description did indeed apply to a species in the "pacarus clade" of Zischkaia. Forster (1964), examined the abovementioned syntype, in addition to another male specimen from Coroico, La Paz, Bolivia (collected by A.H. Fassl), and stated that "this species is apparently widespread in the Yungas, this rare species is similar to the common southern Brazil [Z.] fumata [i.e., Z. pacarus] and it is so similar that it can be seen as subspecies of a single species. In genital apparatus no differences can be observed, however, [Z.] amalda is smaller with lighter brown color of the dorsal side of the wings so that the androconial spot of the males emerges more clearly". Forster (1964: 114, fig. 124) correctly identified Z. pacarus (referred to as Z. fumata), but we disagree with his claim of a lack of genitalic differences between Z. amalda and Z. pacarus, having observed slight differences between the male genitalia of these two species (see Fig. 4A, G). Nevertheless, the specimens of $Z$. amalda deposited at the ZSM examined by Forster were not dissected and the origin of the specimen he dissected is unknown. It is therefore not possible to verify whether he dissected $Z$. amalda or some other similar species, such as $Z$. chullachaki sp. nov., which has similar genitalia. Due to resemblance of this taxon to congeners described in this study, we designate as lectotype of Euptychia amalda Weymer 1911 the male syntype, illustrated by Warren et al. (2018) and deposited at the ZSM, in order to settle the nomenclature (lectotype designation). 


\section{Variation}

The curvature of the VHW median line below $\mathrm{M}_{3}$ is apparently variable; the curvature of the phallobase is also apparently variable.

Distribution (Fig. 14)

This species is currently known from the foothills of the eastern Andes, from Tingo María, Huánuco, Peru to Coroico, La Paz, Bolivia.

Zischkaia arctoa Nakahara, sp. nov.
urn:1sid:zoobank.org:act:AF533240-EA7F-41D3-8100-F9675291FF95

Figs 2C-D, 4B, 14

\section{Diagnosis}

Zischkaia arctoa sp. nov. is similar to Z. amalda, but is distinguished by the concavity of the ventral margin of the apical process of the valva, in addition to the distal margin of the winglet of the aedeagus being shorter compared to the basal margin. The ventral margin of the apical process of the valva is less concave than in $Z$. amalda, and the length of the distal margin of the winglet of the aedeagus is similar to that of the basal margin in $Z$. amalda. However, given the limited number of specimens of both species available for examination, we suggest diagnosing these two species based on their locality; Z. arctoa sp. nov. is currently known from the Cordillera de la Costa, Venezuela and Z. amalda is known to date from the east Andean foothills from central Peru to Bolivia. We do not know of any putative female specimen for this species.

\section{Etymology}

This specific epithet is based on the feminine Latin adjective 'arctoa', in accordance with the feminine generic name, meaning 'northern', 'of the far north', in reference to the fact that this species is the most northerly occurring species of Zischkaia.

\section{Type material examined}

\section{Holotype}

VENEZUELA • ${ }^{\top}$; “// VENEZUELA: DIST. FEDERAL Massif du Naiguata 720-800 m. 28.vii 1943; R. Lichy// Allyn Museum Acc. 1986-5// Genitalic vial SN-17-73 S. Nakahara// UF FLMNH MGCL 1036042//"; FLMNH.

\section{Paratypes $\left.(3 \hat{\partial})^{\lambda}\right)$}

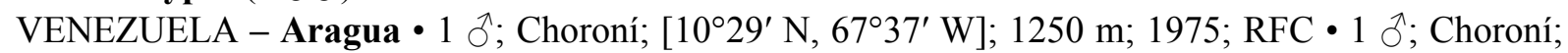

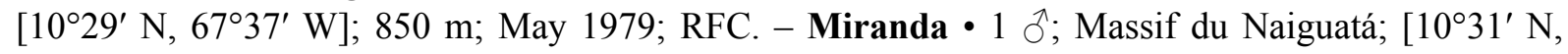
6649’ W]; 3 Jun. 1940; R. Lichy leg.; FLMNH-MGCL-1036041; FLMNH.

\section{Description}

\section{Male}

ForEWING LENGTH. 21-23 mm $(\mathrm{n}=4)$.

HEAD. Eyes naked, with grayish scales at base; frons brownish; post-genal area with lightly colored long hair-like scales and grayish scales; labial palpi with first segment mostly with brownish long hairlike scales; second segment length almost twice as great as eye depth and adorned with brown scales laterally, dorsally mostly with light brownish long hair-like scales, ventrally adorned with brownish and white hair-like scales, about 3-4 times as long as segment width; third segment about two-fifth of second 
segment in length and covered with brownish scales, ventrally with brownish hair-like scales, with slight patch of creamy-white scales laterally; antennae approximately two-fifth of forewing length, with ca 39 segments $(\mathrm{n}=1)$, distal 13-15 segments composing club, club not prominent.

THORAX. Dorsally, laterally and ventrally scattered with grayish scales with long multi-colored hair-like scales.

LEGs. Foreleg brownish, foretarsus slightly shorter than tibia, femur similar to tarsus in length; midleg and hindleg with femur creamy white ventrally, tibia and tarsus grayish dorsally, whitish ventrally, tarsus and tibia spined ventrally, and a pair of tibial spurs present at distal end of tibia.

ABDOMEN. Eighth tergite as stripe at base of eighth abdominal segment, in addition to presence of distal broader patch; eighth sternite divided into two patches.

Wing VENATION. Basal half of forewing Subcosta swollen; base of Cubitus swollen; forewing recurrent vein absent; origin of $\mathrm{M}_{2}$ towards $\mathrm{M}_{1}$ than $\mathrm{M}_{3}$; hindwing humeral vein developed.

WING SHAPE. Forewing subtriangular, apex rounded, costal margin convex, outer margin slightly convex (almost straight), inner margin straight, but rounded towards thorax near base; hindwing slightly elongate, rounded, costal margin almost straight, angled towards thorax near base, outer margin slightly undulating, inner margin slightly concave near tornus, anal lobe convex, slightly round.

Dorsal FOREwING. Ground color light brownish, distally slightly paler; black androconial scales, not prominent, present in middle of DFW, from base to submedian area; trace of submarginal band almost invisible.

DoRSAL HINDWING. Ground color similar to forewing, black androconial scales present in discal and adjacent area, not as prominent as DFW; trace of submarginal band almost invisible (clearly visible in one specimen).

VENTRAL FOREWING. Ground color light chestnut brown; submedian line invisible; dark brown narrow median line extends from near costa to $\mathrm{Cu}_{2}-2 \mathrm{~A}$, in outward diagonal direction, concolorous slightly sinuate submarginal line extending from apex towards tornus, but terminates around $2 \mathrm{~A}$; concolorous marginal line, narrower than submarginal line, extending from apex towards tornus, but terminates around $2 \mathrm{~A}$; fringe dark brownish.

VeNTRAL HINDWING. Ground color similar to forewing; regular dark-brown submedian line almost straight, extending from costal to inner margin; median line almost parallel to submedian line, concolorous, similar in width, passing origin of $M_{3}$, curved inwards after passing origin of $M_{3}$ and posterior end bent inwards in 2A-A; submarginal line extending from apex towards tornus, anterior end occasionally fused with submedian line near costa, undulating, posterior end slightly broadening and occasionally fused to submedian line in $2 \mathrm{~A}-3 \mathrm{~A}$; marginal line, concolorous, slightly undulating along outer margin, thinner than submarginal line; submarginal ocelli from $\mathrm{M}_{1}$ to $2 \mathrm{~A}$ (tiny ocellus in Rs- $\mathrm{M}_{1}$ in three specimens), rounded, pupil appear as scattered silverish scales placed distally, black central spot ringed with orangish ring then with thin dark brownish indistinct ring, ocellus in $\mathrm{Cu}_{2}-2 \mathrm{~A}$ smallest; bright silvery purple ground color visible between submedian line and submarginal line when seen under light; fringe dark brownish.

Genitalia (Fig. 4B). Tegumen rounded in lateral view, elongated posterior projection of tegumen developed, apparently slightly shorter than uncus, tapering posteriorly and hooked at terminal point; combination of ventral arms of tegumen and dorsal arms of saccus sinuous, broadening towards saccus; 
appendices angulares present, but somewhat reduced; saccus anterior half slightly curved upwards, similar to uncus in length; uncus long and narrow, sparsely with hair-like setae, curved in lateral view, rounded at terminal point, posterior end of ventral margin appearing as small projection; either side of base of uncus with hair-like setae; brachia similar to uncus in length, slightly narrower, curved in lateral view, tapering posteriorly and crossing over each other near terminal point; fultura inferior present; valva subtriangular in lateral view, apical process subtriangular, dorsal and ventral margin almost equally convexed, scarcely covered by hairy-like setae; costa developed and triangular, dorsal margin slightly sinuous; phallobase slightly shorter than half of phallus in length, slightly curved; ductus ejaculatorius coming out higher than anterior end of coecum; aedeagus straight with manica covering approximately one-fifth, winglet present, distal opening located ventrally where vesica is visible.

\section{Female}

Unknown or unrecognized.

\section{Variation}

The VFW submedian line traverses in an outward diagonal direction below $M_{3}$ in one examined specimen, whereas it appears rather straight in the other three examined specimens; the size of ocellus in VHW Rs-M is variable, ranging from being almost absent to being clearly visible; the curvature of the VHW submedian line below $\mathrm{M}_{3}$ is apparently variable.

\section{Distribution (Fig. 14)}

This species is known to date from the Cordillera de la Costa, a mountain range extending along the north Venezuelan coast.

\section{Remarks}

Zischkaia arctoa sp. nov. is similar to Z. amalda, and one might argue their conspecificity due to their morphological resemblance. However, these two taxa are treated as different species here mainly due to their geographical isolation and the presence of allopatrically occurring $Z$. abanico sp. nov. between the range of the two species. Zischkaia arctoa sp. nov. occurs in the Cordillera de la Costa, which is isolated from the adjacent Cordillera de la Mérida (the northeastern extension of the tropical Andes) by the flat and scrubby lowlands of the Depression of Unare; $Z$. amalda is known from the eastern slopes of tropical Andes in Bolivia and Peru, which is over $2500 \mathrm{~km}$ (straight line distance) from the known range of $Z$. arctoa sp. nov., and with no records in the intervening Andes despite intensive sampling in at least some regions. Unfortunately, we were unable to obtain DNA data for either of these two taxa to help further clarify the taxonomy, and obviously such data would be very valuable.

Zischkaia chullachaki Nakahara \& Zacca, sp. nov. urn:lsid:zoobank.org:act:EBDD3929-4E74-48BE-B0F9-2FE17A9E0567

Figs 1, 2E-H, 4C, 6A-B, 12E-F, 14

Zischkaia amalda - Lamas et al. 1991: 10 [misidentification]. — Lamas 1994: 165 [misidentification]. — Robbins et al. 1996: 232 [misidentification]. — Mielke et al. 2010: 291 [misidentification].

\section{Diagnosis}

Zischkaia chullachaki sp. nov. is similar to Z. baku sp. nov., but is distinguishable based on posterior projection of tegumen being curved in lateral view (posterior projection of tegumen is rather straight in $Z$. baku sp. nov.); posterior projection of tegumen narrow in dorsal view (posterior projection of tegumen rather broad in dorsal view in $Z$. baku sp. nov.); winglet of aedeagus reduced, almost absent (winglet of aedeagus prominent, clearly visible in $Z$. baku sp. nov.); sclerotized tube reduced, almost 
invisible in lateral view in $Z$. chullachaki sp. nov. (sclerotized tube about half the length of ductus bursae in Z. baku sp. nov.).

\section{Etymology}

The specific epithet is derived from a mythological creature, Chullachaki, a 'forest guardian' known from the Peruvian and Brazilian jungle, in reference to this species known from the Peruvian and Brazilian Amazon. This specific epithet is regarded as a Latinized masuculine noun in apposition.

\section{Type material examined}

\section{Holotype}

BRAZIL • đ; “// 8-10-IX-2004, Reserva Humaitá, Porto Acre, Acre, 200 m, O. Mielke \& Casagrande leg. //DZ 37.009 //BC-DZ Willmott 230 //"; DZUP.

\section{Paratypes (46 $\partial^{\lambda} \hat{\partial}, 3$ 우)}

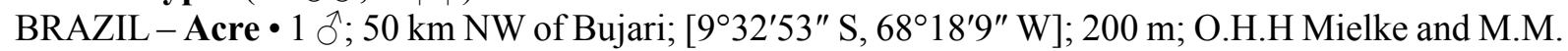
Casagrande leg.; 10-12 Sep. 2004; DZ-36758; DZUP• 1 ``; 6.4 km E Santa Rosa do Purus; [9²8'39" S, 70²6'58" W]; 3-4 Aug. 2008; O.H.H. Mielke and E. Carneiro leg.; DZ-37043; DZUP • 1 o'; Assis

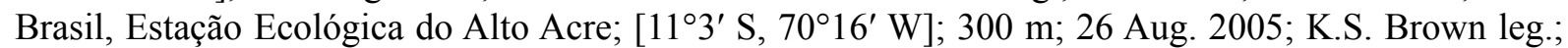

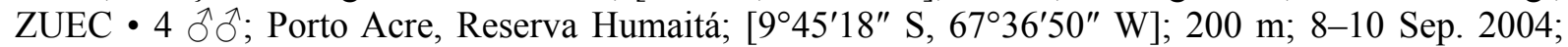
O.H.H. Mielke and M.M. Casagrande leg.; DZ-21235, DZ-21620, DZ-36578, DZ-36848; DZUP.

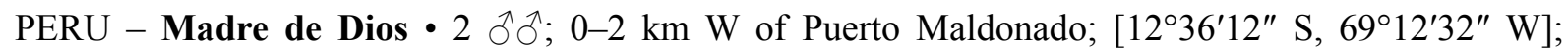
14 Aug. 1981; L.D. Miller; FLMNH-MGCL-1036033, FLMNH-MGCL-1036034; FLMNH • 1 ठ̊; same collection data as for preceding but 16 Aug. 1981; FLMNH-MGCL-1036035; FLMNH・1 ð̊; Boca Río La Torre; [1250' S, 69¹7’ W]; 300 m; 24 Oct. 1983; G. Lamas leg.; MUSM-LEP-105641; MUSM • 1 P; same collection data as for preceding but 24 Sep. 1981; MUSM-LEP-105651; MUSM • 1 ठ; same collection data as for preceding but 26 Sep. 1981; MUSM-LEP-105642; MUSM • 1 đ; same collection data as for preceding but 27 Sep. 1981; MUSM-LEP-105640; MUSM - 1 ते; same collection data as for preceding but 30 Nov. 1979; MUSM-LEP-105643; MUSM - 1 ; ; Cerro Pantiacolla, E slope,

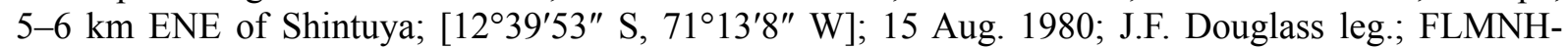
MGCL-1036036; FLMNH 1 त; same collection data as for preceding but 19 Aug. 1980; FLMNH-

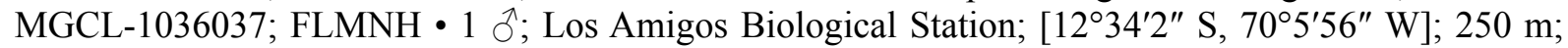
23 Oct. 2005; C. Peña; MUSM-LEP-105649; MUSM • 1 ơ; same collection data as for preceding but

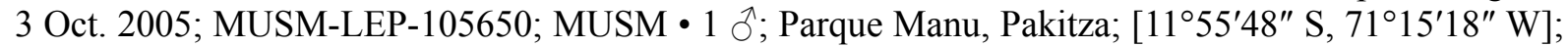
340 m; 10 Oct. 1991; R.K. Robbins leg.; MUSM-LEP-105648; MUSM • 1 q; Parque Manu, Pakitza;

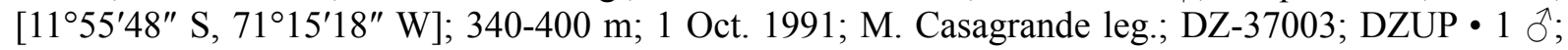
same collection data as for preceding but 11 Oct. 1991; DZ-36733; DZUP• 1 đ; same collection data as for preceding but 13 Oct. 1991; DZ-21228; DZUP • 1 त; same collection data as for preceding but 28 Sep. 1991; DZ-37023; DZUP • 1 क ; same collection data as for preceding but 30 Sep. 1991; DZ-36508; DZUP • 1 क ; (same collection data as for preceding but 30 Sep. 1991; Häuser leg.; DZ-36783; DZUP•

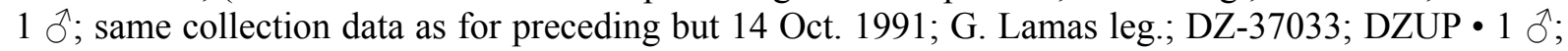
same collection data as for preceding but 27 Sep. 1991; DZ-36983; DZUP • 1 ô; same collection data as

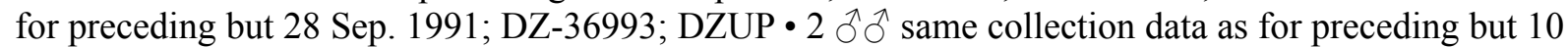
Oct. 1991, Mielke leg.; DZ-36608, DZ-36793; DZUP• 1 ô; same collection data as for preceding but 26 Sep. 1991; DZ-36763; DZUP • 1 ô; same collection data as for preceding but 27 Sep. 1991; DZ-21627; DZUP• 4 ô; same collection data as for preceding but 4 Oct. 1991; DZ-36019, DZ-36753, DZ-36803, DZ-37013; DZUP • 1 ऊ ; same collection data as for preceding but 26 Sep. 1991; R.K. Robbins leg.;

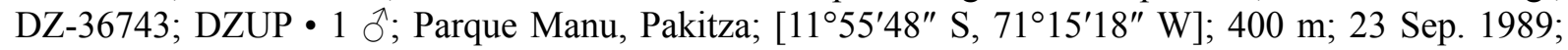
D.J. Harvey leg.; USNM • 1 ; ; same collection data as for preceding but 2 Oct. 1990; G. Lamas leg.; USNM • 1 § same collection data as for preceding but 2 Oct. 1990; G. Lamas leg.; MUSM-LEP-105646; MUSM - $1 \delta^{\uparrow}$; same collection data as for preceding but 8 Oct. 1990; MUSM-LEP-105647; MUSM •

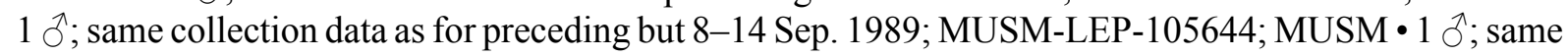


collection data as for preceding but 14 Sep. 1989; M.G. Pogue leg.; MUSM-LEP-105645; MUSM • 1 §;

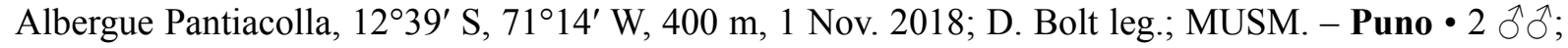

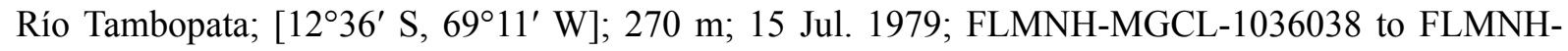

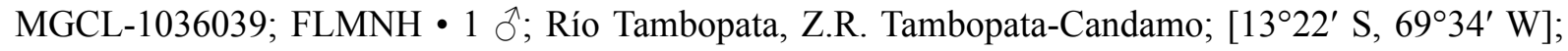
270 m; 1 Jan.; FLMNH-MGCL-1036045; FLMNH • 1 ते; same collection data as for preceding but 26 Aug. 1995; Cambridge University leg.; BMNH(E)-1718103; NHMUK・1 ${ }^{2}$; same collection data as for preceding but 3 Sep. 1995; BMNH(E)-1718102; NHMUK.

\section{Description}

Male

FoREWING LENGTH. 23-25 mm $(\mathrm{n}=28)$.

HEAD. Eyes naked, with grayish scales at base; frons brownish; post-genal area with lightly colored long hair-like scales and grayish scales; labial palpi first segment with whitish scales and light brown long hair-like scales ventrally; second segment length almost twice as great as eye depth and with brown and white scales laterally, dorsally mostly with brownish and whitish hair-like scales, ventrally with brownish long hair-like scales and white hair-like scales, about 3-4 times as long as segment width; third segment almost half of second segment in length and covered with brownish scales, ventrally with brownish hair-like scales, with slight patch of creamy-white scales laterally; antennae approximately two-fifth of forewing length, with ca 39-47 segments $(n=2)$, distal 13-15 segments composing club, club not prominent.

THorax. Dorsally, laterally and ventrally scattered with grayish scales, and long multi-colored hair-like scales.

Legs. Foreleg brownish, foretarsus longer than tibia and femur, tibia shorter than femur in length; midleg and hindleg with femur creamy white ventrally, tibia and tarsus grayish dorsally, whitish to ocher ventrally, tarsus and tibia spined ventrally, and a pair of tibial spurs at distal end of tibia.

ABDOMEN. Eighth tergite as stripe at base of eighth abdominal segment, in addition to presence of distal broader patch; eighth sternite divided into two patches.

Wing VEnAtion. Basal half of forewing Subcosta swollen; base of Cubitus swollen; forewing recurrent vein absent; origin of $M_{2}$ towards $M_{1}$ than $M_{3}$; hindwing humeral developed.

WING SHAPE. Forewing subtriangular and appear elongated, apex angular, costal margin convex, outer margin slightly convex (almost straight), inner margin straight, but rounded towards thorax near base; hindwing slightly elongate, rounded, costal margin almost straight, angled towards thorax near base, outer margin slightly undulating, inner margin slightly concave near tornus, anal lobe convex, slightly round.

DORSAL FOREWING. Ground color grayish brown; prominent black androconial scales present in middle of DFW, from base to submedian region occupying the space between Radius and inner margin; trace of submarginal and marginal line visible.

DoRSAL HINDWING. Ground color similar to forewing, black androconial scales present in discal cell and adjacent area, from $\mathrm{M}_{1}$ to $2 \mathrm{~A}$; trace of submarginal and marginal line visible.

VENTRAL FOREWING. Ground color grayish chestnut brown; submedian line invisible; dark brown narrow median line extends from near costa to $\mathrm{Cu}_{2}-2 \mathrm{~A}$, terminates within this cell, in slightly outward diagonal direction; concolorous undulating submarginal line extending from apex towards tornus, terminates 
around 2A; concolorous marginal line, narrower than submarginal line, extending from apex towards tornus, terminates around $2 \mathrm{~A}$; fringe dark brown.

VENTRAL HINDWING. Ground color similar to forewing; regular dark-brown submedian line almost straight, extending from costal to inner margin, curves inwards in 2A-3A; median line almost parallel to submedian line, concolorous, similar in width, passing origin of $\mathrm{M}_{3}$, curved inwards after passing origin of $\mathrm{M}_{3}$, and posterior end bent inwards in $2 \mathrm{~A}-3 \mathrm{~A}$; undulating submarginal line extending from apex towards tornus, anterior end occasionally fused with submedian line near costa, posterior end slightly broadening and occasionally fused to submedian line in 2A-3A; marginal line, concolorous, slightly undulating along outer margin, narrower than submarginal line; submarginal ocelli from Rs to $2 \mathrm{~A}$, rounded, pupil as scattered silverish scales placed distally, black central spot ringed with orangish ring then with thin dark brownish indistinct ring; light purplish lilac coloration visible between submedian line and submarginal line when seen under lighting; fringe dark brownish.

Genitalia (Fig. 4C). Tegumen rounded in lateral view, elongated posterior projection of tegumen developed, curved upwards in lateral view, apparently shorter than uncus, tapering posteriorly and hooked at terminal point, posterior end of ventral margin appearing as small projection; combination of ventral arms of tegumen and dorsal arms of saccus sinuous, broadens towards saccus; appendices angulares present, but somewhat reduced; saccus straight, similar to uncus in length; uncus long and narrow, sparsely with hair-like setae, curved in lateral view, rounded at terminal point forming small 'bulb'; either side of base of uncus with hair-like setae; brachia similar to uncus in length and width, curved in lateral view, tapering posteriorly and crossing over each other near terminal point; fultura inferior (i.e., juxta) present; valva subtriangular in lateral view, apical process subtriangular, dorsal margin convexed, ventral margin concave, scarcely covered by hairy-like setae, costa developed and triangular, dorsal margin slightly sinuous; phallobase about two-fifth of phallus, rather straight; ductus ejaculatorius coming out higher than anterior end of coecum; aedeagus straight with manica covering about half, winglet present, distal opening located ventrally where vesica is visible.

\section{Female}

FW length $23 \mathrm{~mm}(\mathrm{n}=2)$.

Similar to male except as follows: foreleg whitish, foretarsus first and second subsegments fused; forewing appears slightly more rounded and broad, ground color of both wing surfaces paler; dorsal androconia absent.

FEMALE ABDOMEn AND GENITALIA (Fig. 6A-B): inter-segmental membrane between seventh and eighth tergite not pleated, but folded posteriorly of ostium bursae with its sclerotized region forming a 'scooplike' structure below lamella antevaginalis; lamella antevaginalis fused to lateral sclerotized plate of eighth abdominal segment; lateral plate of eighth abdominal segment expanding laterally with small spiracle at superior third; ductus bursae membranous with a half-ring strongly sclerotized at the median region; corpus bursae three times longer than ductus bursae, with paired signa ventrally occupying $2 / 3$ its length.

\section{Variation}

The VHW ocellus in Rs- $\mathrm{M}_{1}$ is variable in terms of size and presence.

Distribution (Fig. 14)

This species is known from the western Amazon basin (Junín, Puno and Madre de Dios, Peru, and Acre, Brazil). 


\section{Remarks}

See relevant section of $Z$. arenisca sp. nov. regarding discussion on taxonomic status of $Z$. chullachaki sp. nov.

Zischkaia baku Zacca, Dolibaina \& Dias, sp. nov.

urn:1sid:zoobank.org:act:363A2374-8CF5-46CB-A9F8-DA6371590583

Figs 1, 2I-L, 4D, 6C-D, 14

\section{Diagnosis}

See relevant section of $Z$. chullachaki sp. nov.

\section{Etymology}

The specific epithet is derived from the nickname 'Baku' of our friend and Brazilian butterfly researcher, André V.L. Freitas, who has made significant contributions to our understanding of Neotropical butterflies, especially satyrines. His nickname is derived from the Portuguese common name for a nightjar (Caprimulgidae), 'Bacurau', and was given in recognition of his faithful imitations of the song of this bird while at college. The specific epithet is regarded as a Latinized masculine noun in apposition.

\section{Type material examined}

\section{Holotype}

BRAZIL • đ’; “// Imperatriz, MA [Maranhão, Brazil], 18-VI-[19]74, Exc[ursão]. Dep[artamen]to. Zool[ogia, Universidade Federal do Paraná] . //DZ 21.242 //”; DZUP.

Paratypes $(53 \hat{\jmath} \widehat{\partial}, 6$ 우우)

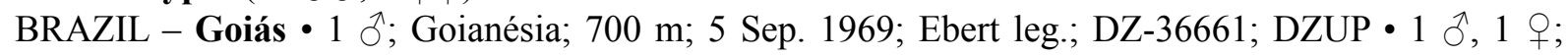
Goianésia; 900 m; 5 Sep. 1969; Ebert leg.; DZ-5572, DZ-5571; DZUP• 1 q; Goiás Velho; [15³4'30" S, 50¹8' W]; 9 Feb. 1980; Gifford leg.; DZ-36943; DZUP. - Maranhão • 1 o, 1 q; Imperatriz; [5³1' S, 47²8' W]; 12 Aug. 1974; Dep. Zool. UFPR leg.; DZ-36733, DZ-36913; DZUP• 1 \%; same collection data as for preceding but 20 Jul. 1974; DZ-36933; DZUP • 1 q; same collection data as for preceding but 25 Aug. 1974; DZ-36404; DZUP • 1 đ̃; same collection data as for preceding but 6 Aug. 1974;

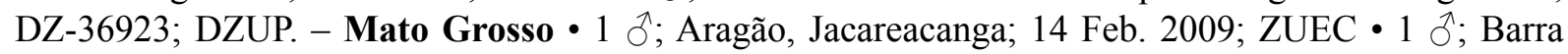
do Garça; 19 Apr. 1978; Gifford leg.; DZ-36673; DZUP • 1 ऊ’; same collection data as for preceding

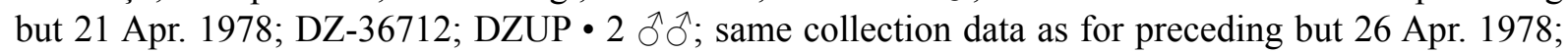
DZ-36623; DZUP • 2 ठิ ơ; Cáceres; 13 Nov. 1984; Buzzi, M. Casagrande, C. Elias and O.H.H. Mielke

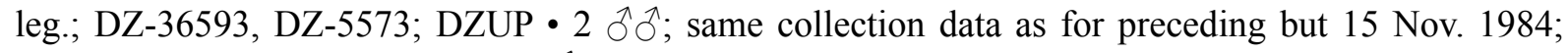
DZ-36703, DZ-36979; DZUP • 1 के; same collection data as for preceding but 18 Nov. 1984; DZ-

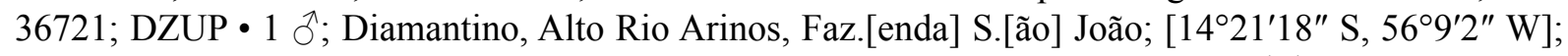

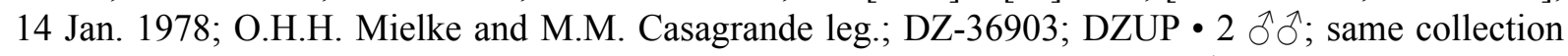
data as for preceding but 17 Jan. 1978; DZ-36893, DZ-36953; DZUP • 1 đ̂; same collection data as for preceding but 21 Nov. 1984; DZ-36681; DZUP • 1 ; ; same collection data as for preceding but 6 Sep. 1978; DZ-36683; DZUP • 1 ○े; same collection data as for preceding but 12 Jan. 1978; O.H.H. Mielke and Furtado leg.; DZ-36603; DZUP • 1 ते; same collection data as for preceding but 14 Jan. 1978; DZ-36701; DZUP • 1 के; same collection data as for preceding but 22 Jan. 1978; DZ-36691;

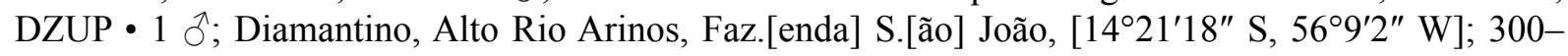
400 m; 2 Sep. 1975; H.-H. Ebert leg.; DZ-36723; DZUP • 1 ; same collection data as for preceding but 26 Jul. 1975; DZ-36593; DZUP • 1 के; same collection data as for preceding but 2 Sep. 1975; E. Furtado leg.; DZ-36583; DZUP• 1 đ̊; Jaciara; 9 Feb. 1967; K.S. Brown leg.; FLMNH-MGCL-1036032;

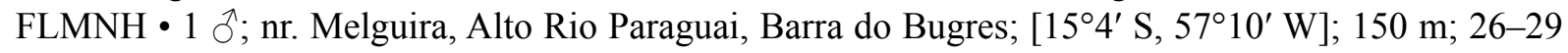
Jul. 1974; H.-H. Ebert leg.; DZ-36693; DZUP• 1 đo’; Rio Teles Pires, Cachoeira Sete Quedas; [9²0’15" S, 
56²46'39" W]; 170 m, 11 Apr. 2009; ZUEC. - Rondônia • 1 đ̧; Fazenda Rancho Grande, Cacaulândia (62 km S Ariquemes, $5 \mathrm{~km} \mathrm{~S}$ of Cacaulândia on linea C-10); [10¹7'51" S, 62 $\left.32^{\prime} 07^{\prime \prime} \mathrm{W}\right]$; 1 Apr. 1995; O. Gomes leg.; FLMNH-MGCL-1036022; FLMNH • 1 त; same collection data as for preceding but 10 Apr. 1994; FLMNH-MGCL-1036023; FLMNH • 1 क; same collection data as for preceding but 11 Feb. 1995; FLMNH-MGCL-1036028; FLMNH • 1 त ; same collection data as for preceding but 15 Apr. 1995; FLMNH-MGCL-1036012; FLMNH • 1 के; same collection data as for preceding but 17 Dec. 1994; FLMNH-MGCL-1036021; FLMNH • 1 त; same collection data as for preceding but

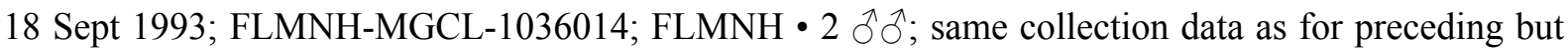
19 Nov. 1994; FLMNH-MGCL-1036017, FLMNH-MGCL-1036027; FLMNH • 1 ; ; same collection data as for preceding but 2 Apr. 1994; FLMNH-MGCL-1036009; FLMNH • 1 ऽं; same collection data as for preceding but 2 Aug. 1993; FLMNH-MGCL-1036016; FLMNH • 1 त; same collection data as for preceding but 21 Jan. 1995; FLMNH-MGCL-1036015; FLMNH • 1 đ; same collection data as for preceding but 22 Apr. 1995; FLMNH-MGCL-1036007; FLMNH • 1 ठ̊; same collection data as for preceding but 24 Jul. 1994; FLMNH-MGCL-1036026; FLMNH - 1 क; same collection data as

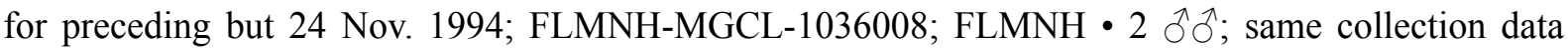
as for preceding but 25 Mar. 1995; FLMNH-MGCL-1036011, FLMNH-MGCL-1036013; FLMNH • 1 ; s same collection data as for preceding but 27 May 1995; FLMNH-MGCL-1036029; FLMNH •

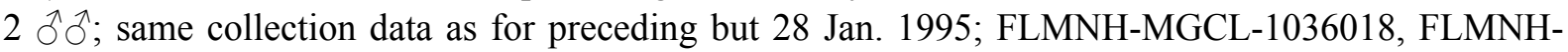

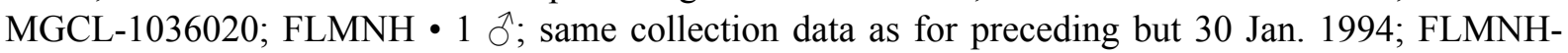

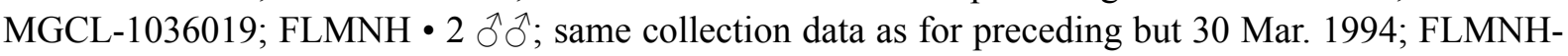
MGCL-1036024, FLMNH-MGCL-1036025; FLMNH • 1 क; same collection data as for preceding but 7 Jan. 1995; FLMNH-MGCL-1036006; FLMNH • 1 ; ; same collection data as for preceding but 8 Jan. 1996; FLMNH-MGCL-1036010; FLMNH • 1 ô; $^{\top}\left[10^{\circ} 32^{\prime} \mathrm{S}, 62^{\circ} 48^{\prime} \mathrm{W}\right]$; 15 Apr. 1995; O. Gomes leg.; FLMNH-MGCL-1036030; FLMNH • 1 §̊; same collection data as for preceding but 7 Jul. 1995; FLMNH-MGCL-1036031; FLMNH.

\section{Description}

Male

FoREWING LENGTH. 21-24 mm $(\mathrm{n}=21)$.

HEAD. Eyes naked, with grayish scales at base; frons brownish with grayish scales and hair-like scales; post-genal area with brownish long hair-like scales and grayish scales; labial palpi first segment with whitish scales laterally and dorsally, and light brown long hair-like scales and whitish long hair-like scales ventrally; second segment length almost twice as great as eye depth and with brown and white scales laterally, dorsally with brownish and whitish hair-like scales, ventrally with brownish and white hair-like scales, about 3-4 times as long as segment width; third segment almost half of second segment in length and covered with brownish scales, ventrally with brownish and whitish hair-like scales, and slight patch of creamy-white scales laterally; antennae approximately two-fifth of forewing length, with ca 45-50 segments $(\mathrm{n}=2)$, distal 12-14 segments composing club, club not prominent.

THORAX. Dorsally, laterally and ventrally scattered with grayish scales with long multi-colored hair-like scales.

Legs. Foreleg brownish, foretarsus shorter than tibia and femur, tibia and femur similar in length; midleg and hindleg with femur creamy white ventrally, tibia and tarsus grayish dorsally, whitish to ocher ventrally, tarsus and tibia spined ventrally, and a pair of tibial spurs present at distal end.

ABDOMEN. Eighth tergite as stripe at base of eighth abdominal segment, in addition to presence of distal broader patch; eighth sternite divided into two patches. 
Wing VENATION. Basal half of forewing Subcosta swollen; base of Cubitus swollen; forewing recurrent vein absent; origin of $\mathrm{M}_{2}$ towards $\mathrm{M}_{1}$ than $\mathrm{M}_{3}$; hindwing humeral developed.

WING SHAPE. Forewing subtriangular and elongated, apex angular, costal margin convex, outer margin slightly convex (almost straight), inner margin straight, but rounded towards thorax near base; hindwing slightly elongate, rounded, costal margin almost straight, angled towards thorax near base, outer margin slightly undulating, inner margin slightly concave near tornus, anal lobe convex, slightly round.

DORSAL FOREWING. Ground color grayish brown; prominent black androconial scales present in middle of DFW, from base to submedian region occupying the space between Radius and inner margin; trace of submarginal and marginal line visible.

DORSAL HINDWING. Ground color similar to forewing, black androconial scales present in discal cell and adjacent area (not reaching the submarginal line), from Rs to $2 \mathrm{~A}$; trace of submarginal and marginal line visible.

VENTRAL FOREWING. Ground color grayish chestnut brown; submedian line invisible; dark brown narrow median line extends from near costa to $\mathrm{Cu}_{2}-2 \mathrm{~A}$, terminates within this cell, in slightly outward diagonal direction, concolorous undulating submarginal line extending from apex towards tornus, terminates around 2A; concolorous marginal line, narrower than submarginal line, extending from apex towards tornus, terminates around $2 \mathrm{~A}$; fringe dark brown.

VENTRAL HINDWING. Ground color similar to forewing; regular dark-brown submedian line almost straight, extending from costal to inner margin, curves inwards in 2A-3A; median line almost parallel to submedian line, concolorous, similar in width, passing origin of $\mathrm{M}_{3}$, curved inwards after passing origin of $\mathrm{M}_{3}$, and posterior end bent inwards in 2A-3A; undulating submarginal line extending from apex towards tornus, anterior end occasionally fused with median line near costa, posterior end slightly broadening and occasionally fused to submedian line in 2A-3A, space between the marginal line and outer margin ochre; marginal line, concolorous, slightly undulating along outer margin, narrower than submarginal line; submarginal ocelli from $M_{1}$ to $2 A$, rounded (but elliptical in $M_{2}-M_{3}$ ), pupil appear as scattered silverish scales placed distally, black central spot ringed with orangish ring then with thin dark brownish indistinct ring; light purplish lilac coloration visible between submedian line and submarginal line when seen under lighting; fringe dark brownish.

Genitalia (Fig. 4D). Tegumen subtriangular in lateral view, somewhat elongated, elongated posterior projection of tegumen developed, straight in lateral view, shorter than uncus, tapering posteriorly and hooked at terminal point, posterior end of ventral margin appearing as small projection; combination of ventral arms of tegumen and dorsal arms of saccus slightly sinuous, broadens towards saccus; appendices angulares present, but somewhat reduced; saccus straight, similar to uncus in length; uncus long and narrow, with sparse hair-like setae, well-curved in lateral view, rounded at terminal point forming a 'bulb'; either side of base of uncus with hair-like setae; brachia smaller than uncus in length, but similar in width, hooked-like in lateral view, tapering posteriorly and not crossing over each other near terminal point; fultura inferior present; valva subtriangular in lateral view, apical process subtriangular, dorsal margin convexed, ventral margin concave, scarcely covered by hair-like setae; costa developed and triangular, dorsal margin slightly sinuous; phallobase about one-third of phallus, curved upwards; ductus ejaculatorius visible; aedeagus straight with manica covering more than half, reduced winglet, distal opening located ventrally where vesica is visible.

\section{Female}

FW length $21-23 \mathrm{~mm}(\mathrm{n}=7)$. 
Similar to male except as follows: foreleg whitish, foretarsus variable in number of tarsomers (see below); forewing appears slightly more rounded and broad, ground color of both wing surfaces paler; DFW androconia absent.

Female ABdomen AND Genitalia (Fig. 6C-D): inter-segmental membrane between seventh and eighth tergite not pleated, but folded posteriorly of ostium bursae with its sclerotized region forming a 'scooplike' structure below lamella antevaginalis; lamella antevaginalis fused to lateral sclerotized plate of eighth abdominal segment; lateral plate of eighth abdominal segment expanding laterally with small spiracle at superior third; ductus bursae basally sclerotized, median region until the connection with corpus bursae membranous, but with three times longer than wide and strongly sclerotized half-ring at the median region; corpus bursae $2 / 3$ longer than ductus bursae, with paired signa ventrally almost entirely occupying the corpus bursae.

\section{Variation}

Width of ventral lines of the wings is variable, especially those from Rondônia which seem to have broader lines; number of female fore tarsomers variably fused.

Distribution (Fig. 14)

This species is known to date from northeastern and midwestern Brazil, namely states of Rondônia, Maranhão, Mato Grosso and Goiás, occurring in forested areas of the western Amazon and within the Cerrado biome.

\section{Remarks}

We were unable to obtain DNA data for this taxon to assess its taxonomic status, especially in relation to $Z$. chullachaki sp. nov., which is phenotypically similar and might arguably be considered conspecific. However, the external morphological differences between these two taxa documented under the 'Diagnosis' section of $Z$. chullachaki sp. nov. support our decision to treat this taxon as a species until further evidence becomes available.

Zischkaia arenisca Nakahara, Willmott \& Hall, sp. nov. urn:lsid:zoobank.org:act:83701B3C-3A99-4BFC-9E8E-18F03C47CE0B

Figs 1, 2M-P, 4E, 6E-F, 9, 14-15A-B

Zischkaia sp. n. - Lamas 1997: 217; 2004: 223.

\section{Diagnosis}

Zischkaia arenisca sp. nov. is readily distinguished from all species of Zischkaia, except for $Z$. argyrosflecha sp. nov., by its elongate, oval VHW ocelli, whereas those ocelli are more circular and smaller in Z. pacarus, Z. amalda, Z. baku sp. nov. and Z. chullachaki sp. nov. Species in the "saundersii clade" also possess somewhat elongate VHW ocelli, but the genitalia differences summarized above (see diagnosis for Zischkaia), in addition to the lack of dorsal androconial scales in males, easily distinguish this species from species in the "saundersii clade". The male DFW and DHW androconial scales in $Z$. arenisca sp. nov. appear somewhat reduced and less prominent compared to those of $Z$. baku sp. nov. and $Z$. chullachaki sp. nov. Furthermore, the forewing apex is somewhat rounded in $Z$. arenisca sp. nov., whereas it is more angled in Z. pacarus, Z. amalda and Z. baku sp. nov. In the female genitalia, the sclerotized tube of the ductus bursae in lateral view appears to be longer in $Z$. arenisca than in Z. chullachaki sp. nov. and Z. pacarus.

Zischkaia arenisca sp. nov. is likely most closely related to Z. argyrosflecha sp. nov., given their similar elongate VHW ocelli, but $Z$. arenisca sp. nov. can be distinguished from $Z$. argyrosflecha sp. nov. by the 
following characters: the lack of silvery-purple scales on the basal side of the VHW ocelli (distad of the submedian line); the lack of or very small VHW ocellus in Rs-M $\mathrm{M}_{1}$, whereas this ocellus is well developed in VHW Rs-M in Z. argyrosflecha sp. nov.; only one winglet being present on the aedeagus, whereas $Z$. argyrosflecha sp. nov. possesses two winglets; the shape of the aedeagus winglet is that of an obtuseangled triangle in $Z$. arenisca sp. nov., whereas it is an acute-angled triangle in $Z$. argyrosflecha sp. nov.; the saccus is longer than the ventral margin of the valva in $Z$. arenisca sp. nov., whereas it is shorter than ventral margin of the valva in $Z$. argyrosflecha sp. nov.; the ventral margin of the apical process of the valva is not concave in $Z$. arenisca sp. nov., whereas it is concave in $Z$. argyrosflecha sp. nov. The female of $Z$. argyrosflecha sp. nov. is unknown and thus it is not possible to compare that sex.

\section{Etymology}

This specific epithet is derived from the Spanish word 'arenisca', meaning 'sandstone', and is treated as a feminine noun in apposition. The name alludes to the apparent strong preference of this species to forest growing on sandstone substrates.

\section{Type material examined}

\section{Holotype}

ECUADOR • ○’; “//ECUADOR: Zamora-Chinchipe Río Nangaritza, Shaime, 4¹9’S, 7840’ W 900m, xi.1997 Jiggins, C.D.// DNA voucher LEP-67941// Genitalic vial SN-17-74 S. Nakahara// Photographed by K. R. Willmott 2004// UF FLMNH MGCL-1036291//"; FLMNH, to be deposited in INABIO.

Paratypes $(20 \hat{\jmath} \hat{\partial}, 4$ 우 $)$

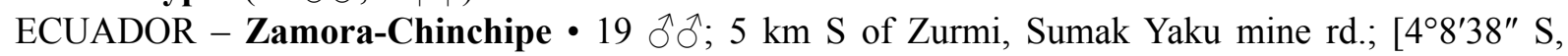
78 $\left.38^{\prime} 57^{\prime \prime} \mathrm{W}\right] ; 1000$ m; 26, 28-29 Jul. 2018; J.P.W. Hall, K.R. Willmott, J.C.R. and J.I.R. Willmott leg.; FLMNH-MGCL-297322 to FLMNH-MGCL-297340; FLMNH • 1 क; same collection data as for preceding; FLMNH-MGCL-297321; FLMNH • 2 우; km 10 Los Encuentros-El Panguí, ridge
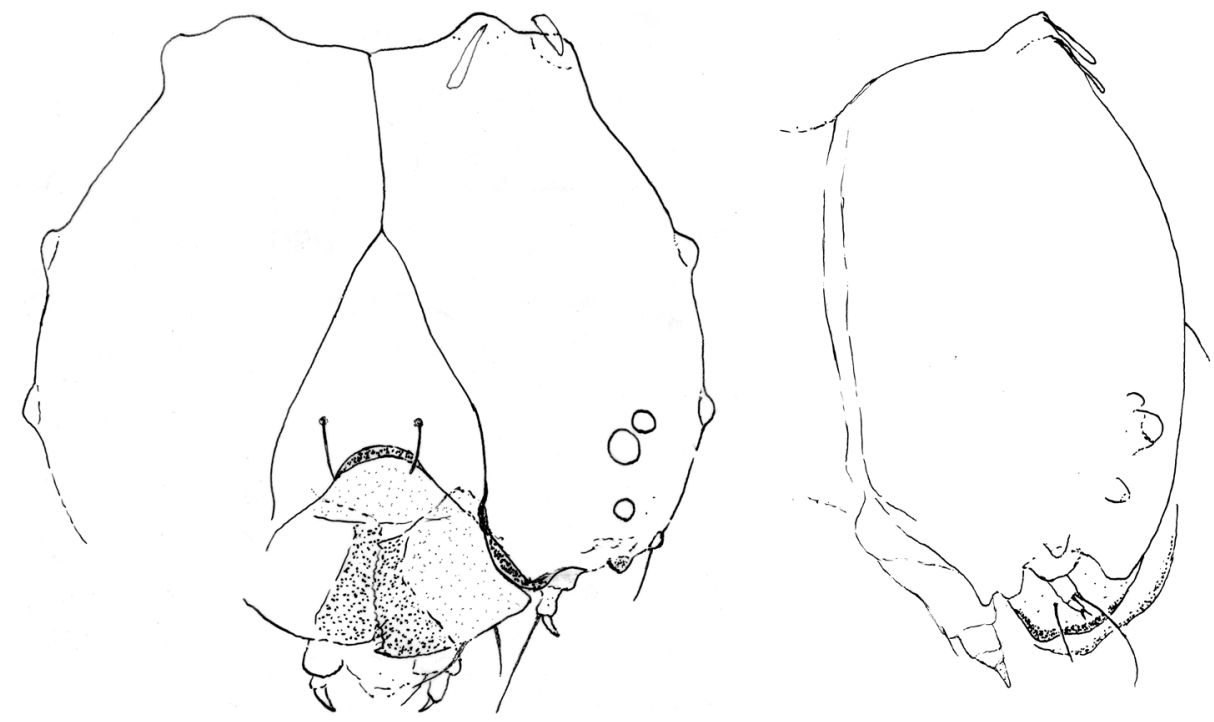

$1 \mathrm{~mm}$

Fig. 9. Zischkaia arenisca Nakahara, Willmott \& Hall, sp. nov., first instar head capsule in anterior and lateral views. 
E San Roque; [342'11" S, 78³5'36" W]; 1050 m; 18-19, 23 Jul. 2018; J.P.W. Hall, K.R. Willmott, J.C.R. and J.I.R. Willmott leg.; FLMNH-MGCL-297319 to FLMNH-MGCL-297320; FLMNH • 1 क; same collection data as for preceding but 4 Aug. 2009; K.R. Willmott and J.P.W. Hall leg.; FLMNH-

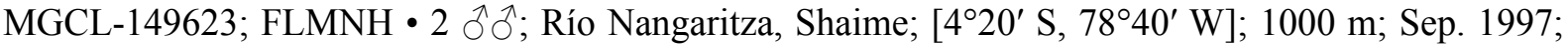
C.D. Jiggins leg.; FLMNH-MGCL-1036290 to FLMNH-MGCL-1036291; FLMNH.

\section{Description}

Male

FOREWING LENGTH. $26-27 \mathrm{~mm}(\mathrm{n}=2)$.

HEAD. Eyes naked, with grayish scales at base; frons brownish; post-genal area with lightly colored long hair-like scales and grayish scales; labial palpi with first segment covered by white and brownish long hair-like scales, in addition to some whitish scales at base; second segment almost twice as long as eye depth and covered with brown scales and hair-like scales laterally, with partially white scales and hairlike scales, dorsally with brownish long hair-like scales, ventrally with black and white hair-like scales, 3-4 times as long as segment width; third segment about one-third of second segment in length, covered with brownish scales, with small patch of creamy-white scales laterally; antennae approximately twofifths forewing length, with ca 44 segments $(n=1)$, distal 16-17 segments composing club, club not prominent.

THORAX. Covered with light brownish hair-like scales.

LEGS. Foreleg brownish, foretarsus slightly shorter than tibia, femur similar to tarsus in length; midleg and hindleg with femur creamy white ventrally, tibia and tarsus grayish dorsally, ocher ventrally, tarsus and tibia spined ventrally, and a pair of tibial spurs present at distal end of tibia.

ABDomEn. Eighth sternite divided into two sclerotized patches: a thin band at base of eighth abdominal segment, and a distal broader patch.

Wing VENATION. Basal half of forewing Subcosta swollen; base of Cubitus swollen; forewing recurrent vein absent; origin of $M_{2}$ nearer $M_{1}$ than $M_{3}$; hindwing humeral vein well developed.

WING SHAPE. Forewing subtriangular, apex rounded, costal margin convex, outer margin slightly convex (almost straight), inner margin straight, but rounded towards thorax near base; hindwing slightly elongate, rounded, costal margin almost straight, angled towards thorax near base, outer margin slightly undulating, inner margin slightly concave near tornus, anal lobe convex, slightly round.

DORSAL FOREWING. Ground color light brownish, distally slightly paler; black androconial scales present in middle of DFW from base to submedian area, except for immediately adjacent area around swollen Subcosta and Cubitus, in addition to area anterior to Radial about distal one-fifth of DFW; trace of submarginal band visible.

DORSAL HINDWING. Ground color similar to forewing, black androconial scales present around distal half of discal cell, extending to adjacent area, trace of submarginal band visible.

VENTRAL FOREWING. Ground color chestnut brown; submedian line invisible; dark brown narrow median line, somewhat indistinct, extending from near costa to $\mathrm{Cu}_{2}$, slightly curved inwards, concolorous slightly sinuate submarginal line extending from apex towards tornus, but terminating half way between $\mathrm{Cu}_{2}$ and $2 \mathrm{~A}$; concolorous marginal line, narrower than submarginal line, extending from apex towards tornus, but terminating half way between $\mathrm{Cu}_{2}$ and $2 \mathrm{~A}$; fringe dark brownish. 
VENTRAL HINDWING. Ground color similar to forewing; regular dark-brown submedian line almost straight, extending from costal to inner margin; median band almost parallel to submedian band, concolorous, similar in width, passing origin of $\mathrm{M}_{3}$ and posterior end bent inwards in $2 \mathrm{~A}-3 \mathrm{~A}$; submarginal band extending from apex towards tornus, anterior end occasionally fused with submedian line near costa, undulating, posterior end slightly broadening and occasionally fused to submedian line in $2 \mathrm{~A}-3 \mathrm{~A}$; marginal line, concolorous, slightly undulating along outer margin, thinner than submarginal line; submarginal ocelli from $\mathrm{M}_{1}$ to $2 \mathrm{~A}$, roughly 'egg'-shaped with pointed end basal, black central spot ringed with orangish ring then with thin dark brownish indistinct ring, pupil consisting of scattered silver scales displaced distally from center, ocelli from $\mathrm{M}_{2}-\mathrm{M}_{3}, \mathrm{M}_{3}-\mathrm{Cu}_{1}$ and $\mathrm{Cu}_{1}-\mathrm{Cu}_{2}$ similar in size, somewhat elongate, those in $\mathrm{M}_{1}-\mathrm{M}_{2}$ and $\mathrm{Cu}_{2}-2 \mathrm{~A}$ about half size of these three ocelli, ocellus in $\mathrm{Rs}-\mathrm{M}_{1}$ a tiny orangish spot; fringe dark brownish.

Genitalia (Fig. 4E). Tegumen rounded in lateral view, elongated posterior projection of tegumen developed, slightly shorter than uncus, basal half somewhat inflated, tapering posteriorly and hooked at terminal point, posterior end of ventral margin as small projection; combination of ventral arms of tegumen and dorsal arms of saccus sinuous, bent at right angle below appendices angulares, broadens towards saccus; appendices angulares present, but somewhat reduced; saccus straight, similar to uncus in length; uncus long and narrow, with sparse hair-like setae, curved ventrally, rounded at terminal point; either side of base of uncus with short hair-like setae; brachia similar to uncus in length and width, curved in lateral view, tapering posteriorly and crossing over each other near terminal point; fultura inferior (i.e., juxta) present; valva subtriangular in lateral view, apical process triangular, ventral and dorsal margin both almost straight, scarcely covered by hairy-like setae, costa developed and triangular, dorsal margin slightly sinuous; phallobase slightly shorter than half of phallus in length, curved upwards; ductus ejaculatorius visible; aedeagus straight with manica covering approximately half, winglet present on dorsal surface, distal opening located ventrally where vesica is visible.

\section{Female}

Similar to male except as follows: FW length $27 \mathrm{~mm}(\mathrm{n}=1)$ : Foreleg whitish, foretarsus divided into five distinct subsegments, fifth subsegment elongate; forewing slightly more rounded, outer margin slightly convex, ground color of both wing surfaces paler.

Female abdomen and Genitalia (Fig. 6E-F): inter-segmental membrane between seventh and eighth tergite not pleated, but folded posteriorly of ostium bursae with its sclerotized region forming a 'scooplike' structure below lamella antevaginalis; lamella antevaginalis sclerotized; posterior approximate three-fourths of ductus bursae sclerotized, remainder membranous; posterior end as a circular hole in posterior view, with edge darker (presumably reflecting degree of sclerotization), surrounding sclerotized area somewhat semi-circular in posterior view; origin of ductus seminalis close to sclerotized portion of ductus bursae; eighth tergite with lateral side sclerotized and fused to lamella antevaginalis; corpus bursae roughly oval in dorsal view, extending across entire abdomen, with two signa located in middle, extending across almost entire corpus bursae, parallel to each other.

\section{Variation}

Most individuals lack an ocellus in VHW Rs-M, or if it is present, it is very small (much smaller than that in $2 \mathrm{~A}-\mathrm{Cu}_{2}$ ). However, in one male (FLMNH-MGCL-297332) and one female (FLMNHMGCL-297320), both barcoded (MUSM-LEP-64859 and MUSM-LEP-64857, respectively), it is rather more developed, approximately half the size of that in cell $2 \mathrm{~A}-\mathrm{Cu}_{2}$. The size of the VHW ocelli is also slightly variable, with smaller ocelli being more rounded. The ventral ground color is darker in some specimens, in which the paler brown rings surrounding the ocelli are also more conspicuously paler. The combination of the ventral arms of the tegumen and dorsal arms of the saccus is sinuous and bent 
at a right angle below the appendices angulares in the male paratype, whereas it is rather straight in the holotype; the curvature of the phallobase is variable between the two dissected males.

\section{Distribution (Fig. 14)}

This species is known to date from a highly restricted range (ca $70 \mathrm{~km}$ between the most northerly and southerly localities) in the Cordillera del Cóndor, an eastern outlier of the tropical Andes that lies along the border of Ecuador and Peru, and several ridges in the adjacent Río Zamora Valley in southeastern Ecuador.

\section{Remarks}

A first instar was found in one dissected female (SN-17-174) and its head capsule is illustrated in Fig. 13. A female specimen from Alfonso Ugarte, Amazonas, Peru in MUSM may represent this species, but the sclerotized portion of ductus bursae extends about three-fourths the distance from ostium bursae to corpus bursae, which contrasts with the rather short 'sclerotized tube' of the two barcoded females from Zamora-Chinchipe, Ecuador (MUSM-LEP-08939 and MUSM-LEP-64858; see Fig. 1). Based on this inconsistency, a female specimen in MUSM [Alfonso Ugarte, 2-3 km N PV3; [3⒌' $\mathrm{S}, 78^{\circ} 26^{\prime} \mathrm{W}$ ]; 1600-1750 m; 16 Jul. 1994; G. Lamas leg.; MUSM-LEP-105658] cannot be identified reliably as Z. arenisca sp. nov. and is, therefore, excluded from the type series.

Zischkaia arenisca sp. nov. is recovered as sister to Z. chullachaki sp. nov. based on COI barcode data (see Fig. 1), but the genetic distance between these two taxa is atypically low for divergence between species (Table 4). Such low divergence might suggest conspecificity of these taxa, but the two species are recovered as moderately supported clades, with a number of consistent morphological differences (see above). In particular, the elongate, 'egg'-shaped VHW ocelli and reduced, less prominent dorsal androconial scales of $Z$. arenisca sp. nov. support regarding these taxa as distinct species rather than as conspecific.

In southeastern Ecuador, this species is known from three localities, all of which support a species of climbing bamboo. Two of these sites are sandstone 'tepuis' that have been mined for their sand, evidently because of its purity, and the poor soils on the slopes and ridges apparently support only stunted forest. An unidentified species of Chusquea Kunth (Poaceae: Bambusoideae) (identified by Lynn Clark) was common at one site, the ridge east of San Roque, where it grew abundantly over remnant trees and bushes along the edges of the dirt road to the mine site on the ridge top. A similar, or the same, bamboo species was likewise common along the Sumak Yaku mine road (see Fig. 15A), and was observed along the edges of forest and inside disturbed forest beside the village of Shaime, although it was absent along most other forest trails and roads in the region. Two females were collected at the edge of a large bamboo patch on the ridgetop at San Roque (see Fig. 15B), flying and resting within $2 \mathrm{~m}$ of the ground from 09:00 to 12:30, while two other females were flying along the edge of a dirt road near bamboo from 11:30-12:30. A number of males were observed and collected flying rapidly 1-4 $\mathrm{m}$ above the ground, from 10:25 to 11:20, in a sunny but sheltered corridor between two patches of vegetation covered with bamboo near a ridgetop at Sumak Yaku. The presence of multiple males and repeated flight paths suggests territorial behavior. Numerous males were also collected at the same site in traps baited with rotting fish, hung $1 \mathrm{~m}$ above the ground in the understorey of secondary forest with abundant bamboo. Despite a reasonable amount of effort collecting and trapping at other forest sites in the region, Z. arenisca sp. nov. was not recorded anywhere else, highlighting its apparent dependence on the climbing bamboo with which the adult butterflies were always closely associated. 
Zischkaia argyrosflecha Nakahara, L. Miller \& Huertas, sp. nov. urn:Isid:zoobank.org:act:D67B48E9-3E2F-42BE-B6AC-01AA0EBD2C48

Figs 2Q-R, 4F, 14

Euptychia saundersi [sic] - D'Abrera 1988: 781, fig. [11] [misidentification].

Euptychia mima - D’Abrera 1988: 78, fig. [12] [misidentification].

\section{Diagnosis}

This species is most similar phenotypically to Z. arenisca sp. nov., and characters that distinguish the two species are discussed in the Diagnosis of that taxon.

\section{Etymology}

This specific epithet is based on the Greek word 'argyros', meaning 'silver', appended to the Spanish word 'flecha', meaning 'arrow', alluding to the arrow-shaped silvery markings along the basal side of the VHW ocelli. This specific epithet is considered to be a Latinized feminine noun.

\section{Type material examined}

\section{Holotype}

PERU • ${ }^{\lambda}$; “// [Peru], Pebas Amazones M. de Mathan fin $X^{\text {bre }} \& 1^{\text {er }} T r .1880 / /$ Ex Oberthür Coll. Brit. Mus. 1927-3.// BMNH (E) 1718075//”; NHMUK.

\section{Paratypes $(7$ ふぇं $)$}

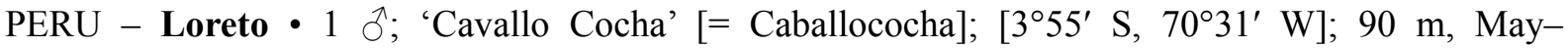
Jul. 1884; BMNH(E)-1718078; NHMUK • $10^{\top}$; Iquitos; [ $3^{\circ} 45^{\prime} \mathrm{S}, 73^{\circ} 15^{\prime} \mathrm{W}$ ]; $100 \mathrm{~m}$, H. Whitely leg.;

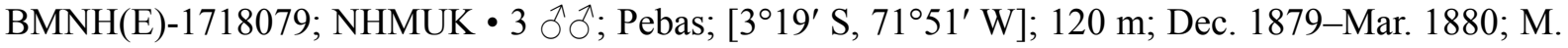
de Mathan leg.; BMNH(E)-1205410, BMNH(E)-1718076, BMNH(E)-1718077; NHMUK • 1 §̊; Río Napo 'Ecuador' [error]; H. Whitely leg.; BMNH(E)-1718074; NHMUK・ 1 đో; Yurimaguas; [554' S, $\left.76^{\circ} 6^{\prime} \mathrm{W}\right] ; 120$ m; P. Hahnel leg.; MNHU.

\section{Description}

\section{Male}

FoREWING LENGTH. $25.5-28 \mathrm{~mm}(\mathrm{n}=3)$.

HEAD. Eyes naked, frons brownish; labial palpi covered by brown and scattered white large scales, long hair-like whitish scales at base; second segment with a mixture of brown and white hair-like thin scales; third segment about one-third of second segment in length, covered with brown and white scales; antennae approximately two-thirds of FW length, with ca 44 segments $(\mathrm{n}=1)$, distal 16-17 segments composing club, club not prominent and with dark ocher color at the base.

THORAX. Covered with bright iridescent brown scales.

LEGS. Foreleg brown with whitish scales, foretarsus slightly shorter than tibia, femur similar to tarsus in length; midleg and hindleg covered with whitish scales at the base, tarsus and tibia brown and a pair of tibial spurs present at distal end of tibia.

AвDomen. Not examined.

Wing VENATION. Basal half of forewing Subcostal swollen; base of Cubitus swollen; forewing recurrent vein absent; origin of $M_{2}$ nearer $M_{1}$ than $M_{3}$; hindwing humeral vein well-developed. 
WING SHAPE. Forewing subtriangular and elongated towards apex, apex somewhat angular, costal margin convex, outer margin slightly convex (almost straight), inner margin straight, but rounded towards thorax near base; hindwing slightly elongate, rounded, costal margin almost straight, angled towards thorax near base, outer margin slightly undulating, inner margin slightly concave near tornus, anal lobe convex, slightly round.

DORSAL FOREWING. Ground color brownish, distally slightly paler; black androconial scales present in middle of DFW from base to submedian area, except for immediately adjacent area around swollen Subcostal and Cubitus, in addition to area anterior to Radius about distal one-fifth of DFW; trace of submarginal band invisible.

DORSAL HINDWING. Ground color similar to forewing, black androconial scales present around distal half of discal cell, extending to adjacent area, trace of submarginal band invisible.

VENTRAL FOREWING. Ground color chestnut brown; submedian line invisible; dark brown narrow median line, somewhat indistinct, extends from near costa to $\mathrm{Cu}_{2}-2 \mathrm{~A}$, bent outwards and fading after passing $\mathrm{Cu}_{2}$, concolorous slightly sinuate submarginal line extending from apex towards tornus, terminates at 2A; concolorous marginal line, narrower than submarginal line, extending from apex towards tornus, terminates at $2 \mathrm{~A}$; fringe dark brownish.

VENTRAL HINDWING. Ground color similar to forewing; regular dark-brown submedian line almost straight, extending from costal to inner margin; median line almost parallel to submedian line, concolorous, similar in width, passing origin of $\mathrm{M}_{3}$; submarginal line extending from apex towards tornus, anterior end fused with submedian line in Rs- $\mathrm{M}_{1}$, slightly jagged, posterior end fused to median line in 2A3A; marginal line, concolorous, slightly undulating along outer margin, thinner than submarginal line; submarginal ocelli from Rs to 2A, roughly oval but somewhat screwed distally, pupil appear as scattered silver scales placed distally, black central spot ringed with orangish ring then with thin dark brownish indistinct ring; silverish-purple scales along basal margin and distal margin of ocelli in $\mathrm{M}_{1}-\mathrm{M}_{2}, \mathrm{M}_{3}-\mathrm{Cu}_{1}$ and $\mathrm{Cu}_{1}-\mathrm{Cu}_{2}$, in addition to distal side of marginal line; fringe dark brownish.

Genitalia (Fig. 4F). Tegumen rounded in lateral view, elongated posterior projection of tegumen developed, apparently slightly shorter than uncus, tapering posteriorly and hooked at terminal point; combination of ventral arms of tegumen and dorsal arms of saccus sinuous, broadens towards saccus; appendices angulares present, but somewhat reduced; saccus straight, similar to uncus in length; fultura inferior (i.e., juxta) present; uncus long and narrow, sparsely with hair-like setae, curved ventrally, rounded and slightly inflated at terminal point, posterior end of ventral margin appearing as small projection; either side of base of uncus with hair-like setae; brachia similar to uncus in length and width, curved in lateral view, tapering posteriorly and crossing over each other near terminal point; valva subtriangular, apical process triangular, dorsal margin almost straight, ventral margin concave, scarcely covered by hair-like setae, costa developed and triangular, dorsal margin slightly sinuous; phallobase about half of phallus in length, almost straight, ductus ejaculatorius coming out higher than anterior end of coecum; aedeagus straight with manica covering approximately one-fifth, two winglets present, distal opening located ventrally where vesica is visible.

\section{Female}

Unknown or unrecognized. 


\section{Variation}

The posterior end of the submarginal line is completely fused to the median line in $2 \mathrm{~A}-3 \mathrm{~A}$ in some specimens, whereas it is detached in others; the intensity of the silvery-purple scales around the VHW ocelli and distal margin of the marginal line is variable.

Distribution (Fig. 14)

This species is known from the western Amazon basin in northern Peru.

\section{Remarks}

Although we do not have DNA data for this taxon, morphological differences between this species and $Z$. arenisca sp. nov. documented above support its specific status.

Zischkaia pacarus (Godart, [1824])

Figs 1, 2S-V, 4G, 6G-H, 8A, 10A-C, 11, 12A-D, 14

Satyrus pacarus Godart, [1824]: 465, 495 (type locality: Brazil).

Euptychia fumata Butler, 1867b: 109, pl. 12, fig. 14 (type locality: "Rio Grande").

Neonympha pacarus - Westwood 1851: 375.

Euptychia pacarus - Butler 1867a: 501; 1868: 38; 1877: 120. — Kirby 1871: 55. — Gaede 1931: 458.

— Weymer 1911: 213. — D'Abrera 1988: 789.

Euptychia fumata - Butler 1867a: 501, nomen nudum.

Euptychia fumata - Butler 1868: 38; 1877: 120. - Kirby 1871: 55; 1879: 134. - Weymer 1911: 213. — Riley \& Gabriel 1924: 22. — Gaede 1931: 446. — Miller 1968: 95. — D’Abrera 1988: 789.

Zischkaia fumata - Forster 1964: 116-118, fig. 123 (the description date of the name was mistakenly given as "1857"). — Brown 1992: 152, fig. 49. — Mielke \& Casagrande 1998: 976. — Brown \& Freitas 2000: 105.

Zischkaia pacarus - Mielke 1995: 772. — Lamas 2004: 223, syn.: fumata Butler, 1867. — Emery et al. 2006: 90. - Beccaloni et al. 2008: 346. - Carneiro et al. 2008: 264. - Peña et al. 2010: 248, 250-251, 253. - Dolibaina et al. 2011: 350. — Silva et al. 2015: 6.

\section{Type material examined}

Neotype (here designated)

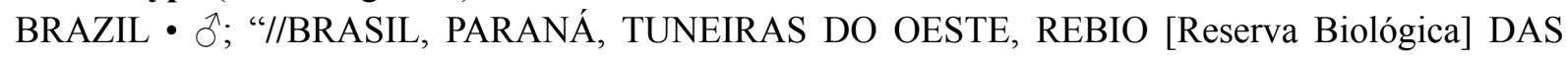
PEROBAS, $23^{\circ}$ 50" 49"S 52॰ 44" 18”'W, 8-X-2012 LABLEP [Laboratório de Estudos de Lepidoptera Neotropical, Departamento de Zoologia, Universidade Federal do Paraná] LEG.// BC-DZ Willmott 246// DZ 36.998//"; DZUP.

Lectotype (here designated)

BRAZIL • đ̃; “(//Rio Grande [do Sul, Brazil] Hewitson coll[ection]. 79-69 Euptychia Fumata, Butl[er]. 2.// BM TYPE No. Rh 3251 Euptychia fumata ${ }^{\Uparrow}$ Butl[er].// Type// BMNH(E) 1267093//”; NHMUK.

Other material examined $(87 \hat{\partial} \widehat{\partial}, 50$ 우)

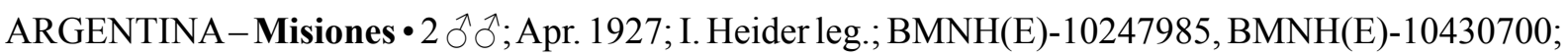

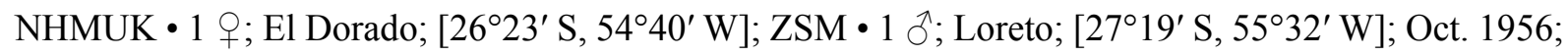
W. Forster leg.; ZSM. 
BOLIVIA - Not located • 1 đ̊; “Torochila” [perhaps representing “Jorochito”]; Garlepp leg.; 1890; MNHU.

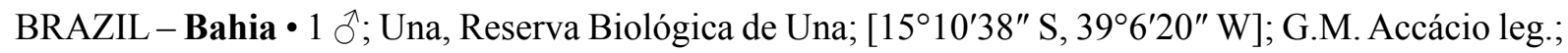
ZUEC. - Espírito Santo • 1 ○ं; Fruhstorfer leg.; BMNH(E)-1205412; NHMUK. - Minas Gerais • 1 \% ; S of Minas Gerais; BMNH(E)-1718052; NHMUK 2 우; Carangola, Serra Rio Glória, Sítio Boa Vista;

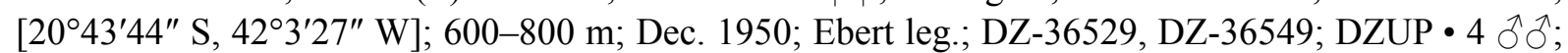

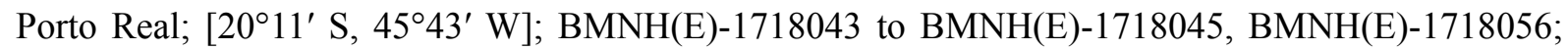
NHMUK - 2 क 9 ; same collection data as for preceding; BMNH(E)-1718050 to BMNH(E)-1718051;

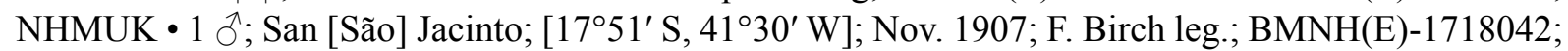
NHMUK. - Paraná • 1 ô; BMNH(E)-1205411]; NHMUK • 1 क; BMNH(E)-1718062; NHMUK • 1 đ̊; Balsa Nova, São Luís do Purunã; 1000 m; 8 Apr. 2006; Beltrami and Selusniaki leg.; DZ-36643;

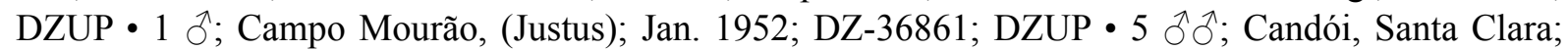

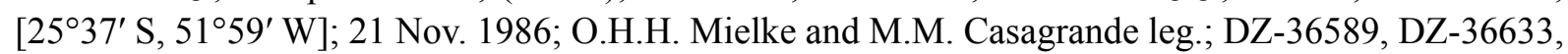
DZ-36831, DZ-36891, DZ-5575; DZUP • 2 우; same collection data as for preceding; DZ-36851, DZ-

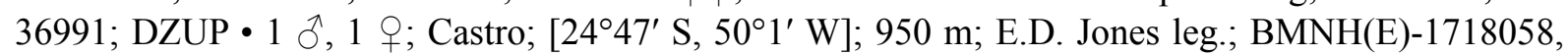
BMNH(E)-1718055; NHMUK • 1 क ; same collection data as for preceding but collector unknown;

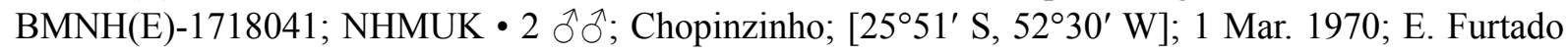

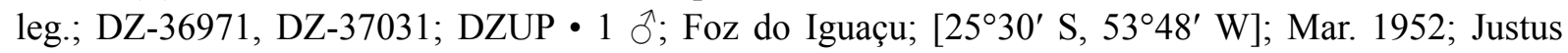
leg.; DZ-37021; DZUP • 1 đ̊; Iguazu; 24 Jan. 1922; BMNH(E)-1718057; NHMUK • 1 q; Londrina; [23 $3^{\circ} 19^{\prime}$ S, $51^{\circ} 10^{\prime}$ W]; 25 Oct. 1985; O.H.H. Mielke and M.M. Casagrande leg.; DZ-37041; DZUP • 1 क; Ponta Grossa; [ $25^{\circ} 6^{\prime} \mathrm{S}, 50^{\circ} 10^{\prime} \mathrm{W}$ ]; Nov. 1956; Justus leg.; DZ-36821; DZUP • 1 웅 Vila Velha;

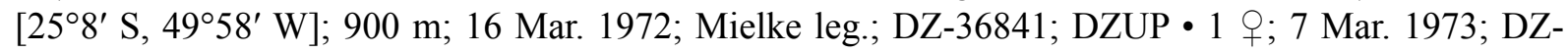

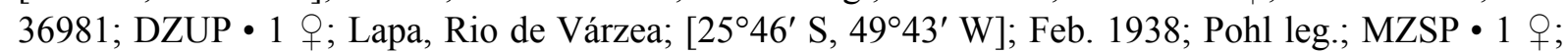

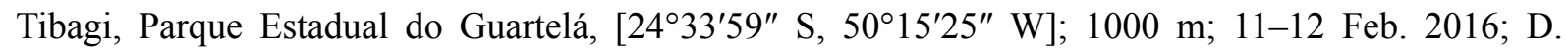
Dolibaina, E. Carneiro and A. Warren leg.; DD-374 6 o $\partial^{\lambda}, 4$ 우; Tuneiras do Oeste, Reserva Biológica das Perobas; [2350'49" S, 5244'18" W]; ('LELN UFPR'); 6 Oct. 2012; DZ-36498, DZ-36728, DZ-

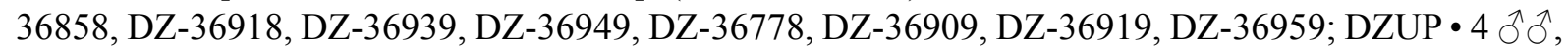
2 우; same collection data as for preceding but 8 Oct. 2012; DZ-36708, DZ-36929, DZ-36989, DZ-

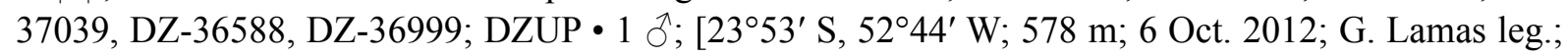
MUSM - 1 ; ; same collection data as for preceding but 8 Oct. 2012; MUSM 1 त; Turvo, Britador;

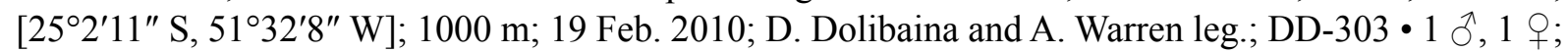

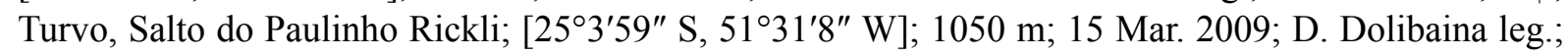
DD-301 to DD-302 - 4 $\widehat{\partial}, 1$ q; same collection data as for preceding but 7 Feb. 2016; D. Dolibaina and Warren leg.; DD-369 to DD-373. - Rio Grande do Sul • 1 q; 1890; Mabilde leg.; MNHU • 1 ; ;

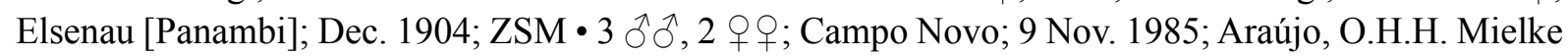
and M.M. Casagrande leg.; DZ-36781, DZ-36941, DZ-36951, DZ-36741, DZ-36751; DZUP • 2 q

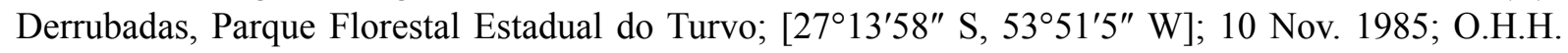
Mielke, Araújo, and M.M. Casagrande leg.; DZ-36761, DZ-36811; DZUP • 1 q; Pelotas; [31 ${ }^{\circ} 45^{\prime}$ S,

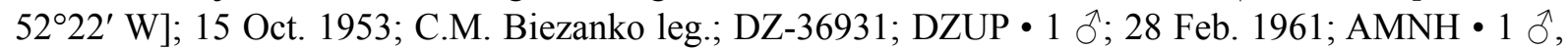

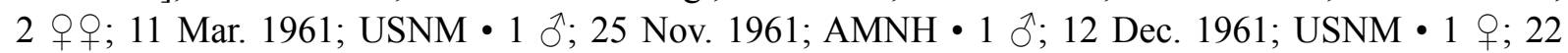
Mar. 1964; AMNH • 1 §; 13 Feb. 1966; V. Becker leg.; DZ-36801; DZUP • 1 क; 6 Nov. 1961; C.M.

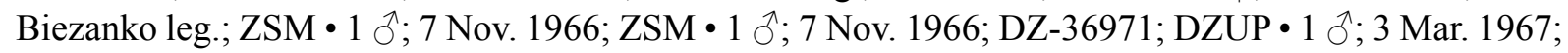
DZ-36791; DZUP • 1 o; 7 Mar. 1970; DZ-21207; DZUP. - Santa Catarina • 1 ơ; Wernicke leg.;

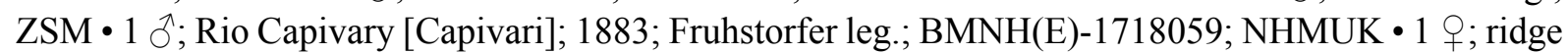
between Joinville and Itajaí, Tajú; [26³4'26" S, 4844'51" W]; Apr.; Schmid leg.; DZ-36881; DZUP •

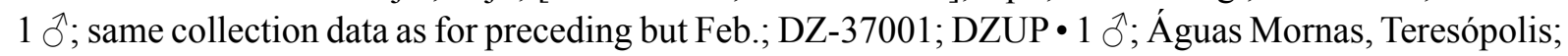
[274ㄴ S, 48 56' W]; BMNH(E)-1718048; NHMUK • 1 q; same collection data as for preceding;

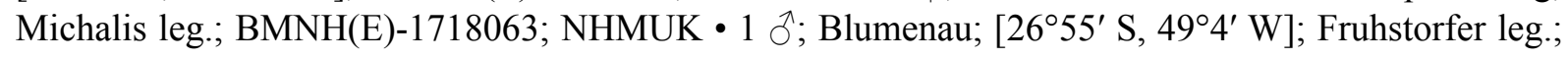


BMNH(E)-1205413; NHMUK • 1 क; Florianópolis, Naufragados; 11 May 2003; E. Carneiro leg.;

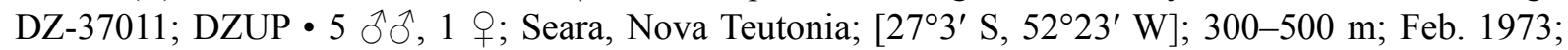
F. Plaumann leg.; FLMNH-MGCL-1036000 to FLMNH-MGCL-1036005; FLMNH • 1 §; 1 Feb. 1972;

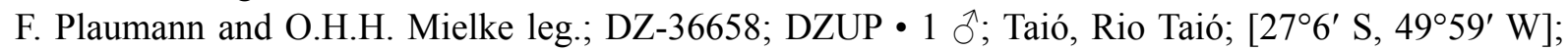
2 Oct. 1935; Pohl leg.; MZSP • 1 o; Timbó; [2649' S, 49¹7' W]; Apr. 1936; Pohl leg.; MZSP. - São

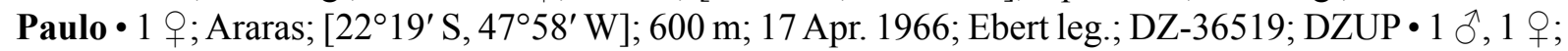
same collection data as for preceding but 6 Jan. 1966; DZ-36499, DZ-5577; DZUP • 1 đं; Casa Branca;

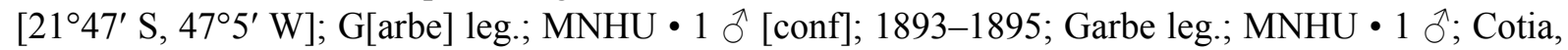
Morro Grande; 22 Nov. 2000; K.S. Brown and A.V.L. Freitas leg.; ZUEC • 1 đ̊; Guararapes, Figueira; 5 Apr. 1940; R.F. d'Almeida leg.; DZ-36509; DZUP • 1 क; Paranapiacaba, Alto da Serra; Feb. 1922;

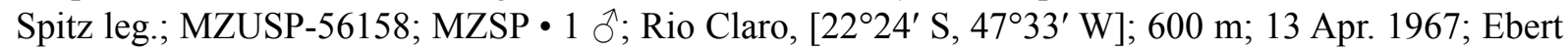
leg.; DZ-36911; DZUP • 1 क; same collection data as for preceding but 26 May 1963; DZ-5576; DZUP •

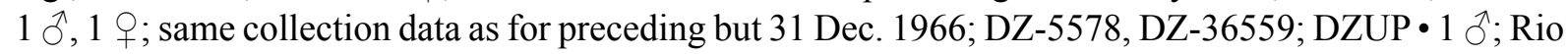

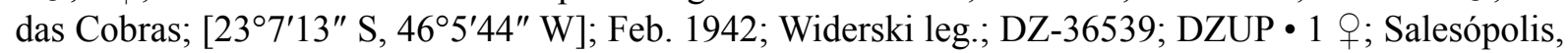

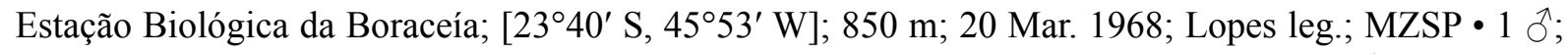
same collection data as for preceding but 27 Feb. 1968; Oliveira Santos leg.; MZSP • 1 đ̃; São Paulo;

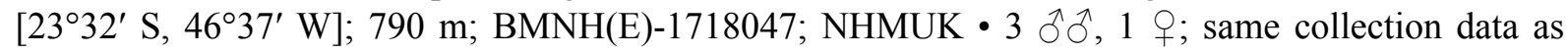
for preceding; Garbe leg.; MZUSP-56159 to MZUSP-56162; MZSP • 1 ก, 1 ค; Teodoro Sampaio, Parque Estadual Morro do Diabo; [22 $30^{\prime}$ S, 52 $2^{\circ} 0^{\prime}$ W]; 250-500 m; 15-18 Mar. 1990; O.H.H. Mielke and M.M. Casagrande leg.; DZ-36569, DZ-36579; DZUP• 1 ' ; same collection data as for preceding

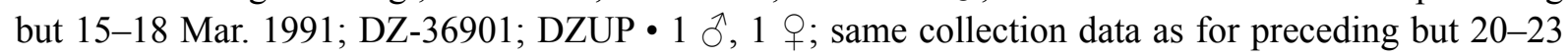
Feb. 1990; DZ-36921, DZ-36613; DZUP • 1 đ̆; same collection data as for preceding but 22-23 May 1990; DZ-36771; DZUP. - No specific locality • 1 § ; H. Rogers leg.; PLT fumata; BMNH(E)-1718068;

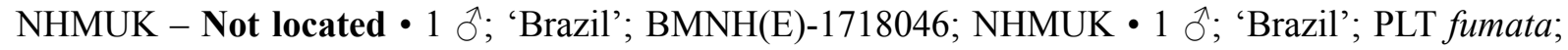
BMNH(E)-1718067; NHMUK・ 1 क ; 'Brazil'; PLT fumata; BMNH(E)-1718066; NHMUK.

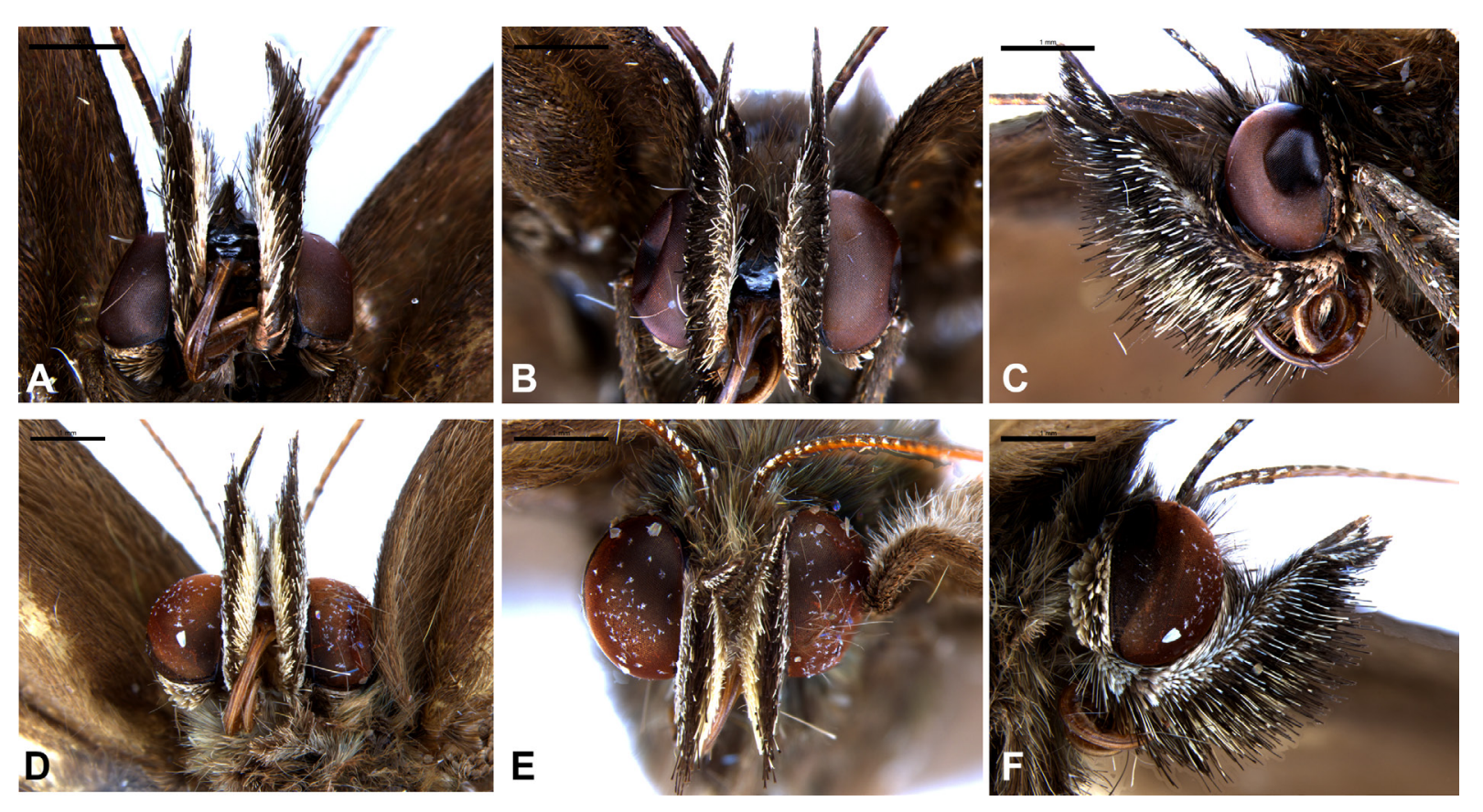

Fig. 10. Head morphology. A-C. Zischkaia pacarus (Godart, 1824) (DZ 36.728). A. Ventral view. B. Frontal view. C. Lateral view. D-F. Z. saundersii (Butler, 1867) (DZ 36.029). D. Ventral view. E. Frontal view. C. Lateral view. 


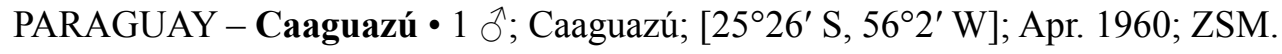

VENEZUELA - Not located • 1 ○̊; 'Venezuela', BMNH(E)-1718065; NHMUK.

COUNTRY UNKNOWN - Not located • 1 đ̊; no data; BMNH(E)-1718049; NHMUK.

\section{Identification and taxonomy}

The male of Zischkaia pacarus is distinguishable from males of other species of Zischkaia by the apical process of the valva being somewhat rectangular with a convex distal margin (Fig. 4G), whereas the apical process of the valva is somewhat triangular in other species of Zischkaia. The female of Z. pacarus can also be distinguished by the genitalia (Fig. 6G-H), namely by the sclerotized tube being one-fourth the length of the ductus bursae, whereas this sclerotized tube is reduced and restricted to the area around the ostium bursae in $Z$. chullachaki sp. nov., more developed and reaching almost half the length of the ductus bursae in Z. baku sp. nov. and Z. arenisca sp. nov.

Godart ([1824]: 495) described Satyrus pacarus based on a single specimen from Brazil, without any mention of the sex of this specimen. He provided a short description of the species (Godart ([1824]: 465), stating "[margin of the] wings entire, dark brown, upper side without spots; forewing under side with two darker wavy lines, hind wing under side with three [darker wavy lines], and five eyes [i.e., ocelli]

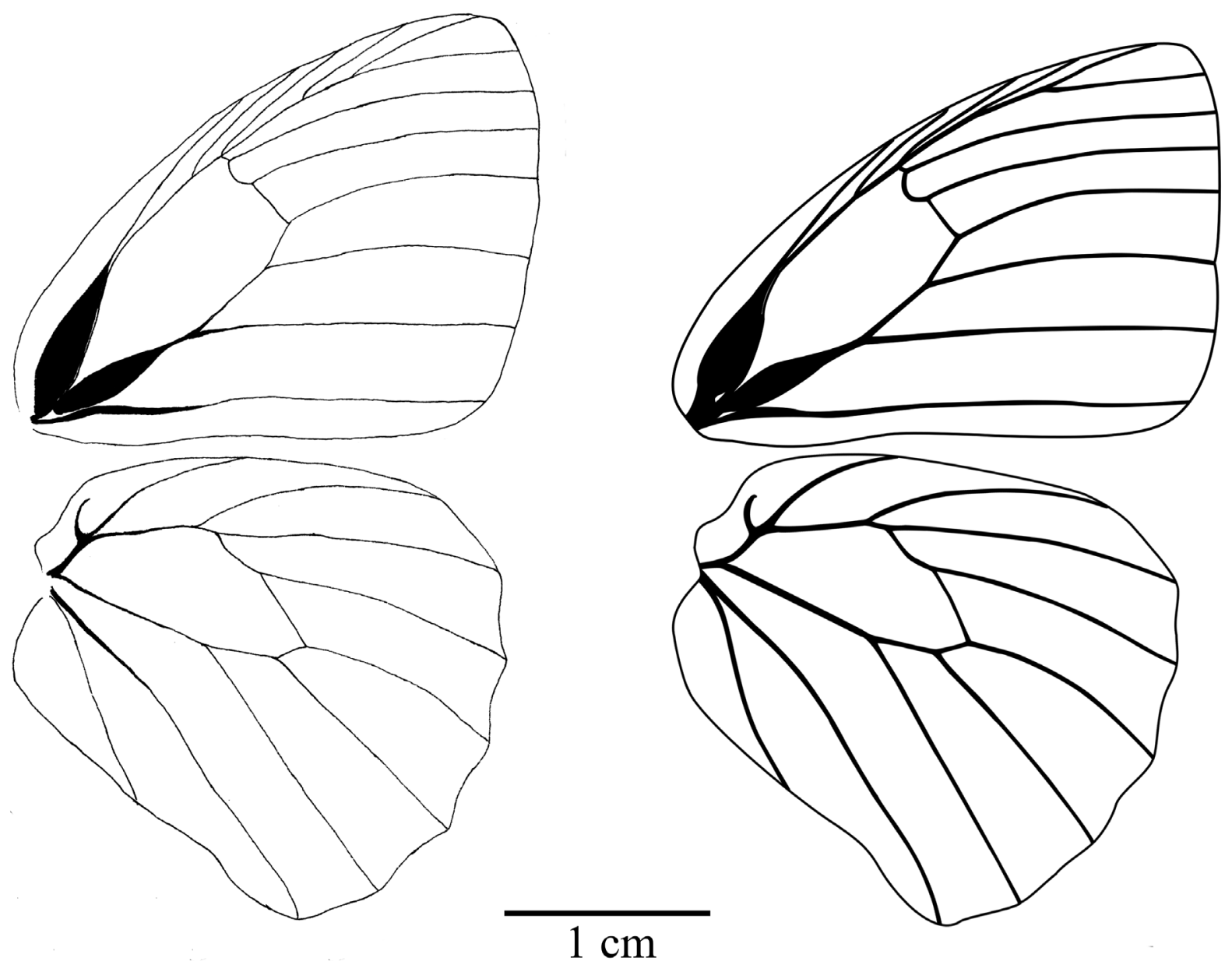

Fig. 11. Zischkaia pacarus (Godart, 1824), wing venation. A. § (FLMHN-MGCL-1036002). B. 우 (MGCL-LOAN 518). 
having the pupil formed by silver dots." The full description on page 495 is lengthier and more precise: "It has approximately two inches [about $5 \mathrm{~cm}$ ] of wingspan. Its wings [margins] are entire, and dark brown in both sides. Its [wings] upper sides are without spots. Its [wings] under sides with, towards the extremity, two lines darker than the ground color. The second wings [i.e., hindwings] have a third similar line, placed transversely towards the middle, and separated from the others by a row of five round, very dark, eyes [i.e., ocelli], with a pupil formed by silver dots, and a brownish iris surrounded by a very dark circle. The first wings [forewings] have no eyes [i.e., ocelli]." (translation based on the original description of both French and Latin version). Certain phenotypic characters described by Godart, namely, no mention of the VFW ocellus (or ocelli), no ocellus (or ocelli) on the dorsal surface, the mention of two lines on the VFW and three lines on the VHW (i.e., lack of VFW submedian line), and the fact this species was allied with several other euptychiine species (e.g., Hermeuptychia sosybius

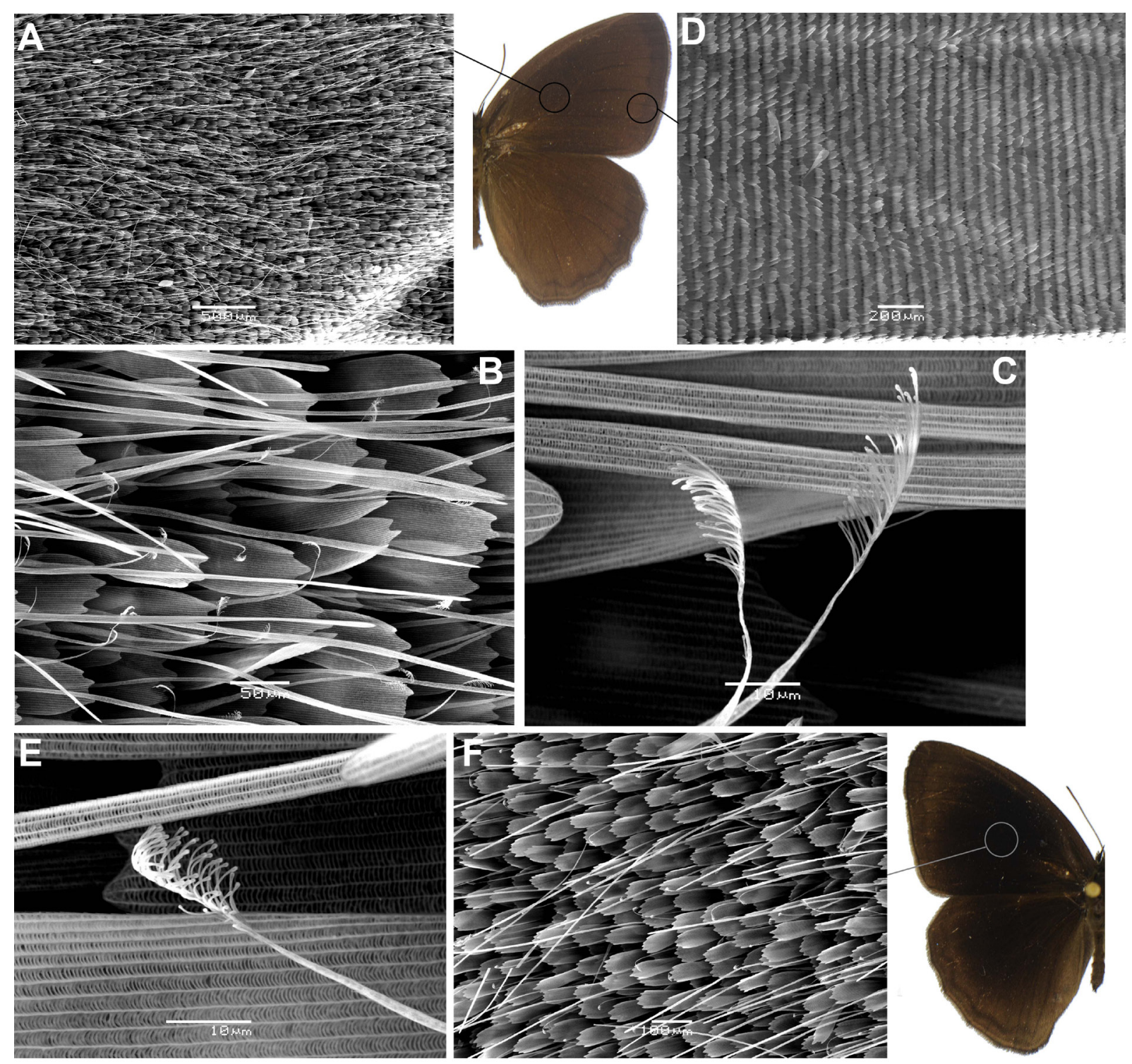

Fig. 12. Wing scales of Zischkaia Forster, 1964. A-C. Images of forewing androconial scales of $Z$. pacarus (Godart, [1824]), showing the presence of plumose androconial scales. D. Typical wing scales of Z. pacarus. E-F. Images of forewing androconial scales of Z. chullachaki Nakahara \& Zacca, sp. nov., showing the presence of plumose androconial scales. 
(Fabricius, 1793)), suggest that Godart was describing a species of Zischkaia. There is no mention of dorsal surface androconia in Godart's description, one of the putative synapomorphic characters for the "pacarus clade" of Zischkaia, and we offer two possible explanations: 1) although the specimen he examined was a male, Godart failed to perceive or did not regard as important the presence of this character; 2) the specimen examined by Godart was a female, and therefore without androconia. Given that the dorsal androconia are not well marked in Z. pacarus, and considering that females are rarer than males, the former is perhaps the more likely. For example, Godart also did not describe the androconial patch of Calisto hysius hysius (Godart, [1824]) (described on page 471) and Forsterinaria necys (Godart, [1824]) (described on page 511), although males of these two species also possess dorsal wing androconial patches. There remains a possibility that Godart was describing $Z$. warreni sp. nov., which also lacks a VFW submedian line and occurs in sympatry with Z. pacarus. However, Z. warreni sp. nov. has a much narrower geographic range and is much scarcer than Z. pacarus in museum collections (43 specimens examined of the former species and 138 of the latter). Most likely, the holotype (fixed by monotypy, following Article 73.1.2. of the ICZN (1999)) of pacarus should have been collected in Minas Gerais or Rio de Janeiro, where Z. warreni sp. nov. is apparently rare (see below). Furthermore, at least some of the species described by Godart are not known or are very rare within the range of $Z$. warreni sp. nov. (e.g., Godartiana byses (Godart, [1824]), see Zacca et al. (2017), Adelpha epione (Godart, [1824]), see Willmott (2003)), suggesting that the type of Z. pacarus might have came from further east in southern Brazil. We therefore contend that Godart's description most likely referred to Z. pacarus as treated here. The holotype of $S$. pacarus has not been located in any museums where specimens from Godart's collection are usually found (e.g., MNHN; Royal Scottish Museum, Edinburgh (Grimshaw 1897; Horn et al. 1990; Bland 2019)). Therefore, a male specimen deposited at the DZUP (Fig. 2), which we also barcoded and included in the phylogeny (BC-DZ 246), is designated as the neotype of Satyrus pacarus Godart, [1824] in order to settle the nomenclature (neotype designation).

Butler (1867a) introduced the name Euptychia fumata, but in a way that failed to fulfill Article 12.1 of the ICZN (1999), as the name was not accompanied by a description, definition, or indication of the taxon it denotes. Therefore, the name was correctly recognized as a nomen nudum by Lamas (2004). Subsequently, Butler (1867b) properly described Euptychia fumata Butler, 1867 based on an unknown number of specimens from "Rio Grande" (likely the state of Rio Grande do Sul, southern Brazil) from Hewitson's collection. Given the presence of other similar Zischkaia species in southern Brazil, a male syntype, deposited in the NHMUK, which compares closely to the description and illustration provided by Butler (1867b), is here designated lectotype, in order to settle the nomenclature (lectotype designation). Euptychia fumata Butler, 1867 was treated as a junior subjective synonym of Z. pacarus by Lamas (2004). Although Lamas (2004) did not provide any justification for this synonymy, the lectotype of E. fumata, here designated, compares closely with Godart's description of S. pacarus and the neotype male designated above; therefore, we retain Euptychia fumata Butler, 1867 as a junior subjective synonym of $Z$. pacarus.

\section{Variation}

The conspicuous dorsal androconia is variable, from being slightly to moderately marked; the VHW ocellus in Rs- $\mathrm{M}_{1}$ is variable in terms of presence and development; the visibility of the bright silvery purple ground color between the VHW submedian line and submarginal line when seen under direct light is also apparently variable, from absent to present.

\section{Distribution (Fig. 14)}

This species is known from southwestern and southern Brazil to northeastern Argentina, in the states of Minas Gerais, São Paulo, Paraná, Santa Catarina, Rio Grande do Sul (Brazil), in the department of Caaguazú (Paraguay) and the province of Misiones (Argentina). Old records from Amazon Superior, Brazil, Bolívia and Venezuela probably refer to mislabeled specimens. 


\section{Remarks}

In Araucaria forests in Paraná, adults of Z. pacarus are found during the summer either on small and isolated or large and continuous patches of the bamboo Merostachys Spreng. (Poaceae: Bambusoideae) (Fig. 16A, C). Males fly fast, up to $5 \mathrm{~m}$ above the ground, with several individuals engaged in patrolling flight. Females fly slowly and lower than males. Butterflies are never found away from the bamboo, and they are more active between the middle of the morning and the beginning of the afternoon. The preferred habitat of $Z$. pacarus in Araucaria forests suggests that the species likely uses Merostachys as the caterpillar host plant. In addition, according to A.V.L Freitas (pers. comm. in Beccaloni et al. 2008), larvae feed on Bambusa (Poaceae: Bambusoideae).

Zischkaia abanico Nakahara \& Petit, sp. nov. urn:lsid:zoobank.org:act:ECB82262-F5E0-4C0A-9FDB-468065263D73

Figs $1,2 \mathrm{~W}-\mathrm{X}, 4 \mathrm{H}, 14,15 \mathrm{C}$

\section{Diagnosis}

Zischkaia abanico sp. nov. is readily distinguishable from other species in the "pacarus clade" by the shape of the apical portion of the valva, which is somewhat rectangular with a convex (i.e., projecting) distal margin in lateral view, whereas the apical process of the valva is more triangular in other species of Zischkaia, except for Z. pacarus. Zischkaia abanico sp. nov. and Z. pacarus are in fact similar in terms of the shape of the valva, as well as other external characters, including wing pattern, and these two taxa cannot be distinguished externally, although our DNA 'barcodes' data clearly suggest they are not conspecific (see Fig. 1). In fact, these two taxa can be distinguished by their range, with $Z$. abanico sp. nov. known from the slopes of the Andes from Colombia to Ecuador and Z. pacarus known from southern and southeastern Brazil to northeastern Argentina. We do not know of any putative female specimen for this species.

\section{Etymology}

The specific epithet is based on the name of the river, Río Abanico, which flows below the ridge where the holotype was captured; the site is thus referred to as as the 'Abanico ridge' among lepidopterists. This specific epithet is considered as a latinized masculine noun in apposition.

\section{Type material examined}

\section{Holotype}

ECUADOR • O’; “//11926 Euptychia sp. 2002, 1213 Ecuador 9 de Octubre, M-Sgo [Morona-Santiago], 1600m JCP// DNA voucher LEP-37388// prep. genit. 575 19.07.2017/J.Lorenc Zischkaia sp Nueve do Octubre Ecuador//"; JEPE, to be deposited in MZUJ.

Other material examined $(2 \hat{\jmath})$

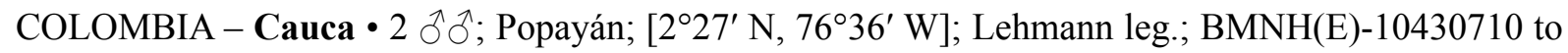
BMNH(E)-10430711; NHMUK.

\section{Description}

\section{Male}

ForeWING LENGTH. $23 \mathrm{~mm}(\mathrm{n}=1)$.

HEAD. Eyes naked, with grayish scales at base. Frons brownish. Post-genal area with lightly colored long hair-like scales and grayish scales. Labial palpi with first segment mostly with brownish long hairlike scales; second segment length almost twice as great as eye depth and adorned with brown scales laterally, dorsally mostly with light brownish long hair-like scales, ventrally adorned with brownish and 
white hair-like scales, about 3-4 times as long as segment width; third segment about two-fifth of second segment in length and covered with brownish scales, ventrally with brownish hair-like scales, with slight patch of creamy-white scales laterally. Antennae approximately two-fifth of forewing length, with ca 39 segments $(\mathrm{n}=1)$, distal 13-15 segments composing club, club not prominent.

THORAX. Dorsally, laterally and ventrally scattered with grayish scales with long multi-colored hair-like scales.

LEGS. Foreleg brownish, foretarsus slightly shorter than tibia, femur similar to tarsus in length; midleg and hindleg with femur creamy white ventrally, tibia and tarsus grayish dorsally, whitish ventrally, tarsus and tibia spined ventrally, and a pair of tibial spurs present at distal end of tibia.

ABDOMEN. Eighth tergite as stripe at base of eighth abdominal segment, in addition to presence of distal broader patch.

Wing VENATION. Most of forewing Subcostal swollen; base of Cubitus swollen; forewing recurrent vein absent; origin of $\mathrm{M}_{2}$ towards $\mathrm{M}_{1}$ than $\mathrm{M}_{3}$. Hindwing Humeral developed.

WING SHAPE. Forewing subtriangular, apex rounded, costal margin convex, outer margin slightly convex (almost straight, but see also below), inner margin straight, but rounded towards thorax near base; hindwing slightly elongate, rounded, costal margin almost straight, angled towards thorax near base, outer margin slightly undulating, inner margin slightly concave near tornus, anal lobe convex, slightly round.

DoRSAL FOREWING. Ground color light brownish, distally slightly paler; black androconial scales, not prominent, present in middle of DFW, from base to submedian area; trace of submarginal and marginal band almost invisible.

DoRSAL HINDWING. Ground color similar to forewing, black androconial scales present in discal cell and adjacent area, not as prominent as DFW; trace of submarginal band almost invisible (clearly absent in one specimen).

VENTRAL FOREWING. Ground color light chestnut brown; submedian line invisible; dark brown narrow median line extends from near costa to $\mathrm{Cu}_{2}-2 \mathrm{~A}$, in slightly outward diagonal direction, concolorous slightly sinuate submarginal line extending from apex towards tornus, but terminates around $2 \mathrm{~A}$; concolorous marginal line, narrower than submarginal line, extending from apex towards tornus, but terminates around $2 \mathrm{~A}$; fringe dark brownish.

VENTRAL HINDWING. Ground color similar to forewing; regular dark-brown submedian line almost straight, extending from costal to inner margin, passing origin of $\mathrm{M}_{1}$; median line almost parallel to submedian line, concolorous, similar in width, passing origin of $\mathrm{M}_{3}$, and posterior end bent inwards in 2A-3A; submarginal line extending from apex towards tornus, undulating, posterior end slightly broadening and apparently fused to submedian line in 2A-3A; marginal line, concolorous, slightly undulating along outer margin, thinner than submarginal line; submarginal ocelli from Rs to $2 \mathrm{~A}$ (ocellus in Rs-M absent in one specimen), rounded, pupil appear as scattered silverish scales placed rather distally, black central spot ringed with orangish ring then with thin dark brownish indistinct ring, ocellus in Rs- $\mathrm{M}_{1}$ smallest, if present; bright silvery purple ground color visible between submedian line and submarginal line when seen under light; fringe dark brownish.

Genitalia (Fig. 4H). Tegumen rounded in lateral view, elongated posterior projection of tegumen developed, apparently slightly shorter than uncus, tapering posteriorly and hooked at terminal point; 
combination of ventral arms of tegumen and dorsal arms of saccus sinuous, broadens towards saccus; appendices angulares present, but somewhat reduced; saccus anterior half slightly curved upwards, similar to uncus in length; uncus long and narrow, sparsely with hair-like setae, curved ventrally, rounded at terminal point, posterior end of ventral margin appearing as small projection; either side of base of uncus with hair-like setae; brachia similar to uncus in length, slightly narrower, curved in lateral view, tapering posteriorly and crossing over each other near terminal point; fultura inferior present; valva subtriangular in lateral view, apical process subtriangular, somewhat pointy distal end, scarcely covered by hairy-like setae; costa developed and triangular, dorsal margin slightly sinuous; phallobase slightly shorter than phallus in length, curved; ductus ejaculatorius not examined; aedeagus straight with manica not examined, winglet present, distal opening located ventrally where vesica is visible.

\section{Female}

Unknown or unrecognized.

\section{Variation}

The FW outer margin is more curved in the holotype, whereas it is straighter in the two examined specimens from Colombia; the VHW median line is wavy below the origin of $M_{3}$ in the holotype, whereas it is rather straight in the two Colombian specimens.

\section{Distribution (Fig. 14)}

This species is known from two localities only, the eastern Andes of Ecuador (Morona-Santiago) (Fig. 15C) and the Cauca valley in Colombia (Cauca). However, there is some doubt about the reliability of the latter locality, as discussed further below.

\section{Remarks}

We excluded from the type series the two male specimens from Popayán, Colombia, listed above, despite the male genitalia of the dissected specimen (BMNH(E)-10430711) being identical to that of the holotype male, in particular in the apical portion of the valva being somewhat rectangular with a convex (i.e., projecting) distal margin in lateral view. However, given the absence of other specimens of this evidently rare species from Colombia or other localities in northern Ecuador, and the otherwise low overlap in the butterfly fauna between Morona-Santiago and the Cauca valley, we considered it reasonably likely that the Colombian specimens might have been mislabeled. In particular, there are several mislabeled specimens of Ithomiini (Nymphalidae) in the NHMUK also labeled as having been collected by Lehmann in Popayán, Colombia, including Dircenna loreta loreta Haensch, 1903 (a lowland west Amazonian taxon, 1 đ), Melinaea marsaeus mothone (Hewitson, 1860) (an east Andean foothill

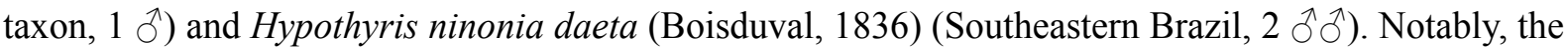
last mentioned taxon occurs within the range of Z. pacarus, so it is possible that the two Colombian specimens are actually mislabeled $Z$. pacarus. Thus, although Popayán is a somewhat plausible locality for this species, and certainly this taxon should be searched for in Colombia, we decided to treat the presence of this species in Colombia as requiring confirmation.

\section{Zischkaia saundersii (Butler, 1867)}

Figs 1, 3A-D, 5A, 7A-B, 8B, 10D-F, 13-14

Euptychia saundersii Butler, 1867a: 500, pl. XL, fig. 17 (type locality: Ega [= Tefé]).

Euptychia saundersii - Butler 1868: 38; 1877: 120. - Kirby 1871: 55; 1879: 132. - Weymer 1911: 213. — Riley \& Gabriel 1924: 52. — Gaede 1931: 464. — Forster 1964: 117. 
Euptychia saundersi [sic] - D’Abrera 1988: 781.

Zischkaia saundersii - Robbins et al. 1996: 232. — Lamas \& Grados [1997]: 58. — Lamas 2004: 223.

\section{Type material examined}

Lectotype (here designated)

BRAZIL • + ; “//Ega [Tefé, Amazonas, Brazil], U[pper]. Amazon[a]s [River]. H[enry]. W[alter]. Bates.// Godman-Salvin Coll[ection]. 1904. - 1. Euptychia saundersi [sic], Butl[er].// Euptychia saundersii Butler Monog[raph]./type// SYN-TYPE// saundersii/ o Ega// BMNH(E) 1718073//"; NHMUK.

\section{Paralectotypes}

BRAZIL • 1 ภૈ; “//B.M. TYPE No. Rh. 3248 Euptychia saundersi [sic] § Butl[er].// Pernambuco. [Brazil]. Pres[ented]. by Mrs Smith 45 - 70// Euptychia saundersii Butler Monog[raph].// Type/ Euptychia saundersii Butler ô//SYN-TYPE// Pernambuco[, Brazil]/ 45 70// BMNH(E): 1267094// NHMUK 010247986//”; NHMUK • 1 q; “//Pernambuco[, Brazil]. Pres[ented]. By Mrs Smith 45 - 70.// Pernambuco/ 45 70// BMNH(E) 1718070//”; NHMUK.

Other material examined $(13 \widehat{\partial}, 4$ 우 $)$

BRAZIL - Maranhão • 1 đ ; Feira Nova do Maranhão, $26 \mathrm{~km}$ E of Fazenda Forquilha dos Brejos; [6 59'12.7'’S 46 25'47.4”W]; 13-16 Apr. 2011; Mielke \& Casagrande leg.; DZ-38159; DZUP. -

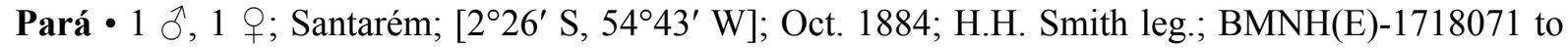
BMNH(E)-1718072; NHMUK. - Pernambuco • 1 ô; PLT saundersii; BMNH(E)-1267094; NHMUK. -

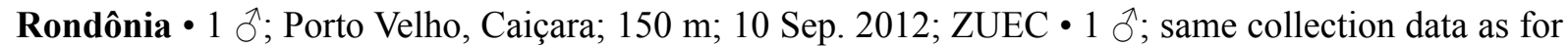
preceding but 8 Oct. 2013; ZUEC. - Not located $\bullet 2$ $\widehat{\jmath}$; 'Brazil'; ZSM.

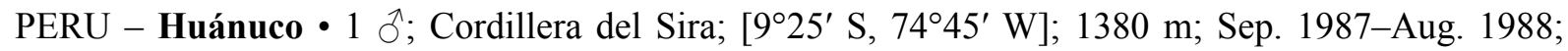
Exp. Universidad Viena leg.; MUSM-LEP-105654; MUSM. - Madre de Dios - 1 q; Parque Manu, Pakitza; [11 ${ }^{\circ} 55^{\prime} 48^{\prime \prime}$ S, $71^{\circ} 15^{\prime} 18^{\prime \prime}$ W]; 340 m; 5 Oct. 1991; M.M. Casagrande leg.; MUSM-LEP-105657; MUSM • 1 đ; same collection data as for preceding but 14 Oct. 1991; H. Lamas leg.; DZ-37029; DZUP• 1 P; same collection data as for preceding but 15 Oct. 1991; Mielke leg.; DZ-36969; DZUP • 1 ठ̊; same collection data as for preceding but 340-400 m; 13 Oct. 1991; M.M. Casagrande leg.; DZ-36649; DZUP - 1 †; same collection data as for preceding but 14 Oct. 1991; DZ-5580; DZUP • 1 ô; same collection data as for preceding but 15 Oct. 1991; DZ-5579; DZUP • 1 o ; same collection data as for preceding but 9 Oct. 1991; Mielke leg.; DZ-21221; DZUP • 1 §ै; same collection data as for preceding but 15 Oct. 1991; R.K. Robbins; DZ-36619; DZUP• 1 के; same collection data as for preceding but $400 \mathrm{~m} ; 18$ Oct. 1990; G. Lamas leg.; MUSM-LEP-105656; MUSM • 1 o; same collection data as for preceding but 14 Oct. 1990; R.K. Robbins leg.; MUSM-LEP-105655; MUSM.

\section{Identification and taxonomy}

Zischkaia saundersii is distinguished from other species in the "saundersii clade" by the metallic silvery blue shading between the submedian line and the marginal line on the VHW. However, although not as prominent as in Z. saundersii, similar VHW shading, sometimes somewhat purplish, may be seen in the three new species described below. For this reason, in addition to color, which can fade over time, the following genitalic characters enable confident identification of this species with respect to the three other species in the "saundersii clade" (see diagnosis of "pacarus clade" for genitalic characters to distinguish $Z$. saundersii from species in that clade): 1) the 'bulb'-like projection of the tegumen is rather small, pointing posteriorly (larger in Z. mielkeorum sp. nov. and Z. warreni sp. nov.); 2) the apical process of the valva is somewhat narrow and pointing upwards in lateral view (more or less straight in $Z$. mielkeorum sp. nov. and $Z$. warreni sp. nov.); the signa are long, extending almost the entire length of the corpus bursae (shorter in $Z$. mielkeorum sp. nov. and $Z$. warreni sp. nov.). 
Euptychia saundersii was described by Butler (1867a) based on an unspecified number of specimens from Tefé, Amazonas, Brazil, in the collection of Bates, and an unstated locality in the state of Pernambuco, Brazil. Three likely syntypes were located at the NHMUK, based on the information provided in the original description. The illustration provided in the orginal description (Butler 1867a: pl. XL, fig. 17) clearly shows a specimen with a silvery blue shading between the VHW submedian line and marginal line. Furthermore, the description by Butler (1867a: 500) of $Z$. saundersii was also based on a specimen with these VHW markings: "Upper wings brown, with two fine and indistinct marginal lines: body grayish-brown, antennae rusty-brown. Lower wings paler, with a violet tinge, the apical area of the HW with a greenish or violet tinge, with two dark brown central lines, diverging near the FW costa, the distalmost [of these two lines] somewhat angled [curved] in the middle of the HW [should be the FW], with the margin narrowly darker, the marginal and submarginal lines narrow and dark brown; HW with five oval ocelli and rarely with one tiny apical [ocellus], the first and fifth the smallest, black, ringed with brown, surrounded by dark brown and with tiny silver pupils; body dark grey-brown". The description and illustration closely match a female syntype from Tefé, Amazonas, Brazil (BMNH(E) 1718073), and because of the possibility that the type series contains several taxa, as discussed further below, we designate this specimen as the lectotype of Euptychia saundersii Butler, 1867 (lectotype designation). The syntype male from Pernambuco figured in Warren et al. (2018), which has the characteristic handwritten label "Euptychia saundersii Butler Monog[raph].", does not possess the VHW grayish shading of the lectotype. We examined the distal side of the valva of this syntype, which appears to be more or less straight, as in Z. mielkeorum sp. nov. and Z. warreni sp. nov. (see Fig. 5). Thus, the male syntype from Pernambuco is most likely not conspecific with the lectotype of $Z$. saundersii, and the taxonomic status of this specimen requires further investigation. If the male specimen from Pernambuco is correctly

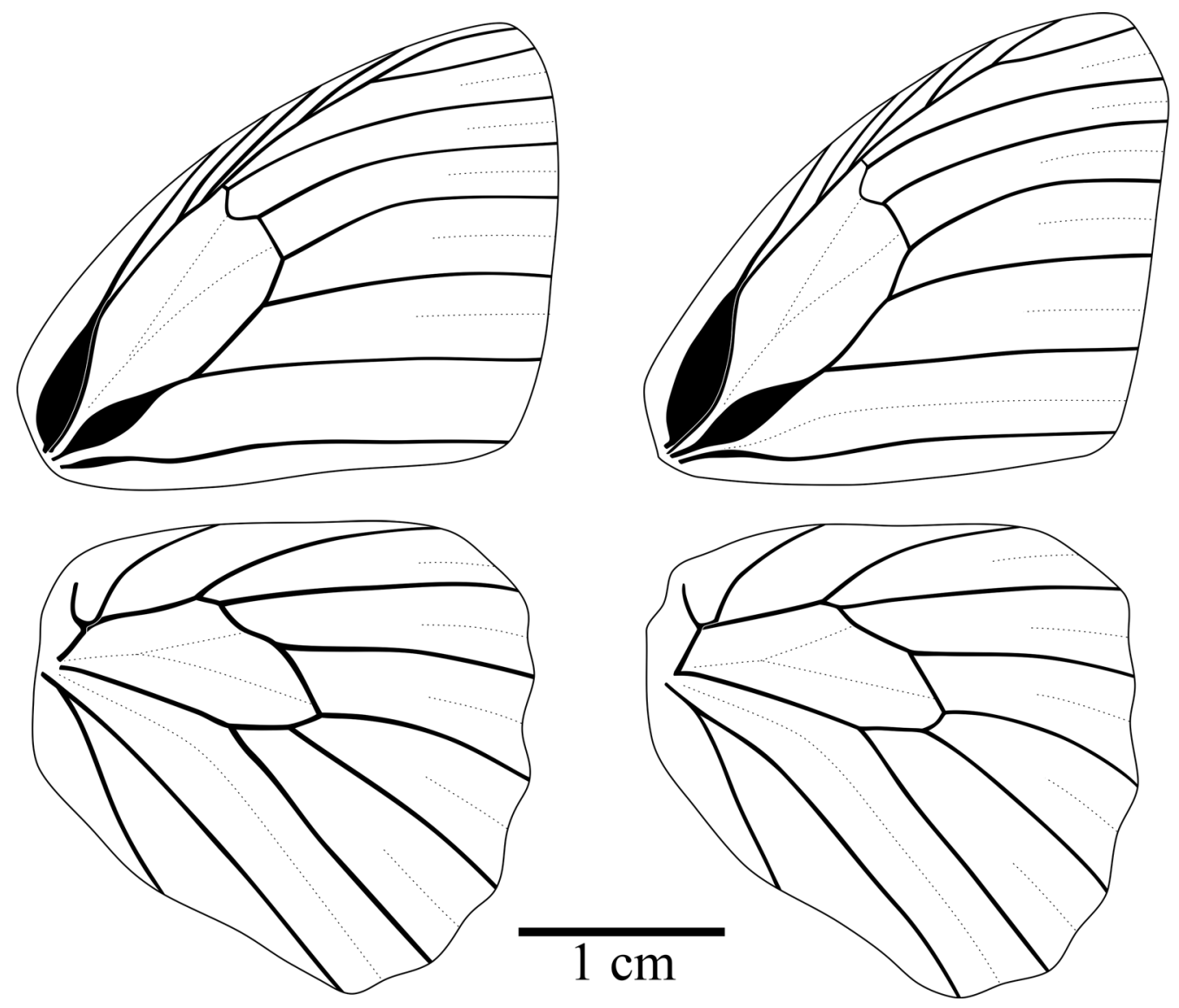

Fig. 13. Zischkaia saundersii (Butler, 1867), wing venation. A. ô (DZ 37.029). B. $\subsetneq$ (DZ 36.646). 
labeled, then the origin of the female syntype from Pernambuco is also questionable, given that this specimen does have silvery blue shading between the VHW submedian line and marginal line, as in the Amazonian lectotype. Clearly, reliably labeled material from Pernambuco is needed to clarify the presence of this species, or other Zischkaia taxa, in that region.

\section{Variation}

The size of the ocellus in VHW Rs-M $\mathrm{M}_{1}$ is variable, ranging from being almost absent to clearly visible.

Distribution (Fig. 14)

This species is reliably known from the Amazon basin, in the states of Rondônia, Pará and Maranhão, Brazil, and the departments of Huánuco and Madre de Dios, Peru. The apparently conflicting phenotypes of the two known specimens labeled as from Pernambuco, Brazil (discussed further above) makes the presence of this species in that region uncertain and requiring confirmation.

\section{Remarks}

A male specimen from Maranhão, Brazil (DZ 38.159) phenotypically resembles Z. saundersii from the Amazon basin except for the VHW metallic silvery blue shading between the submedian line and marginal line being somewhat paler. The genitalia of this male from Maranhão are identical to $Z$. saundersii from the Amazon basin, in particular in the apical process of the valva being somewhat narrow and pointing upwards in lateral view. This character separates $Z$. saundersii from two other closely related species (Z. mielkeorum sp. nov. and Z. warreni sp. nov.), so we regard this specimen from Maranhão as $Z$. saundersii in the absence of further information.

Zischkaia josti Nakahara \& Kleckner, sp. nov. urn:1sid:zoobank.org:act:572C5B5F-D4A5-45BB-A8DE-3B3C3DED5575

Figs 1, 3E-H, 7C-D, 14, 16A-B

\section{Diagnosis}

Zischkaia josti sp. nov. is closest (see discussion below) and similar to Z. mielkeorum sp. nov., but female specimens of these two taxa are distinguishable by the rather elongated, 'egg'-shaped VHW ocelli of $Z$. josti sp. nov., whereas the VHW ocelli are smaller and more rounded rather than elongated in Z. mielkeorum sp. nov. These two species can also be separated by the presence of small sclerotized region at approximately one-third distance from ostium bursae to corpus bursae, whereas this sclerotization is apparently absent in Z. mielkeorum sp. nov. The range of these two taxa can also be informative regarding identification, namely $Z$. josti sp. nov. known from Guianas, whereas $Z$. mielkeorum sp. nov. occuring in Southeastern Brazil. See also relevant sections for $Z$. saundersii and $Z$. warreni sp. nov.

\section{Etymology}

This specific epithet is dedicated to Bernhard Jost, a lepidopterist from Switzerland who collected the holotype and kindly allowed us to examine this specimen. The specific epithet is regarded as a Latinized masculine noun in the genitive case.

\section{Type material examined}

\section{Holotype}

VENEZUELA - + ; "//Venezuela Bolivar Chivaton, Strasse nach [route to] Kavanayen $1360 \mathrm{~m}$ N05'37'55"/W061'41'40" 08.Oktober 2007 B. Jost// DNA-voucher 68763//”; BEJO, to be deposited in NMBE. 


\section{Paratype}

GUYANA • 1 q; “//GUYANA: Acarai Mts./ridge Sipu R. 2500-3000” 31.X.-10.XI.2000 1²2.2” N 58 57.9”'W Leg. S. Fratello et al// USNM ENT 00233844// DNA voucher LEP-18704// Genitalia dissection 2018-002 D.J.Harvey//"; USNM.

\section{Description}

\section{Male}

Unknown or unrecognized

\section{Female}

ForEWING LENGTH. $25-26 \mathrm{~mm}(\mathrm{n}=2)$.

HEAD. Eyes naked, with greyish scales at base; frons dark brown, with creamy-white scales and lightly colored long hair-like scales; labial palpi first segment with whitish long hair-like scales and whitish scales, second segment length almost twice as great as eye depth and covered with brownish scales laterally, with partially whitish scales, dorsally with brownish long hair-like scales, ventrally with blackish long hair-like scales and whitish long hair-like scales, about 3-4 times as long as segment width; third segment slightly shorter than half of second segment in length and covered with blackish scales, antennae cannot be examined.

THORAx. Dorsally light brown with lightly colored scales and long hair-like scales; ventrally brownish, with greyish scales lightly colored long hair-like scales.

Legs. Foretarsus divided into five distinct subsegments; midleg and hindleg tibia and tarsus grayish dorsally, whitish ventrally, tarsus and tibia spined ventrally, and pair of tibial spurs present at distal end of tibia.

ABdomen. Eighth tergite uniformly sclerotized.

Wing VENATION. Basal half of forewing Subcosta swollen; base of Cubitus swollen; forewing recurrent vein absent; origin of $\mathrm{M}_{2}$ towards $\mathrm{M}_{1}$ than $\mathrm{M}_{3}$; hindwing humeral developed.

WING SHAPE. Forewing subtriangular and elongated, apex angular, costal margin convex, outer margin slightly concave, inner margin straight, but rounded towards thorax near base. Hindwing slightly elongate, rounded, costal margin almost straight, angled towards thorax near base, outer margin undulating, inner margin slightly concave near tornus, anal lobe convex, slightly round.

DORSAL FOREWING. Ground color light brownish, apex and distal area slightly darker.

DoRSAL HINDWING. Ground color similar to forewing, trace of posterior half of submarginal line visible.

VENTRAL FOREWING. Ground color greyish brown; dark brown narrow median line, almost straight, extends from near costa to origin of $\mathrm{Cu}_{2}$, terminates after crossing origin of $\mathrm{Cu}_{2}$; concolorous submedian line, wider than median line, somewhat sinuous, extending from near costa to $2 \mathrm{~A}$, traversing in outward direction below $\mathrm{M}_{3}$; concolorous submarginal line, similar to submedian line in width, slightly undulating, traversing from apex towards tornus, terminating around $2 \mathrm{~A}$, somewhat undulating; concolorous marginal line, narrower than submarginal line, extending from apex towards tornus; fringe grayish.

VENTRAL HINDWING. Ground color similar to forewing; median line, concolorous with VFW median line, almost straight, extending from costal margin to inner margin, apparently bent inwards near inner margin; concolorous submedian line almost parallel to median line, appear slightly wider, passing origin of $\mathrm{M}_{3}$, 
posterior end bent inwards in $2 \mathrm{~A}-3 \mathrm{~A}$; undulating submarginal line extending from apex towards tornus, anterior end apparently fused with submedian line near costa, posterior end not fused to submedian line, terminates in 2A-3A; concolorous marginal line, slightly undulating along outer margin, appear wider than submarginal line; submarginal ocelli from $\mathrm{M}_{1}$ to $2 \mathrm{~A}$, oval, pupil appear as scattered silverish scales placed distally, black central spot ringed with orangish ring then with thin dark brownish indistinct ring; fringe grayish.

Female Genitalia (Fig. 7C-D). Inter-segmental membrane between seventh and eighth tergite not pleated, but expanded with posterior edge forming a smooth, curving sclerotized band anterior to ostium bursae that seamlessly borders the broad, sclerotized plate of lamella antevaginalis, which narrows ventally to encircle ostium bursae and is indented throughout with the edges forming raised lip; lamella antevaginalis fused to lateral sclerotized plate of eighth abdominal segment; ductus bursae membranous, small sclerotized region present at one-third distance from ostium bursae to corpus bursae; origin of ductus seminalis located between sclerotized plate and ostium bursae; corpus bursae roughly oval in dorsal view, with two signa located in middle, parallel to each other.

\section{Variation}

The paratype possesses an ocellus in the VHW cell Rs- $\mathrm{M}_{1}$, whereas the ocellus is absent in this cell in the holotype female.

\section{Distribution (Fig. 14)}

This species is known from the type locality in Bolívar state, Venezuela and a single site in the Acarai Mountains, in southern Guyana.

\section{Remarks}

Despite our initial hypothesis of the holotype and paratype being two different species, the small genetic distance $(0.3 \%)$ based on DNA 'barcodes' between the holotype (MUSM-LEP-68763) and paratype (MUSM-LEP-18704) do not support this hypothesis. The distance between these two Guianan specimens and three barcoded individuals of $Z$. mielkeorum sp. nov. (BC-DZ-225, 248, 249) fall within $0.9-1.6 \%$, which is in accordance with rather low inter-specific genetic distance of two other taxa of Zischkaia regarded as species (Z. chullachaki sp. nov. and Z. arenisca sp. nov.; see Table 4) compared to many other euptychiine butterflies (pers. obs.). The wing pattern differences between the two Guianan females documented above, combined with their geographical isolation, might merit subspecific status. However, due to the fact that only a single specimen is known from each site, we feel it is premature to draw any conclusion as to the importance of this geographic variation. We thus regard the observed phenotypic difference between these two Guianan females to represent intra-specific variation and treat these specimens as a single taxon. See also corresponding section of Z. mielkeorum sp. nov. for relevant discussion for these two species.

Zischkaia mielkeorum Dolibaina, Dias \& Zacca, sp. nov. urn:lsid:zoobank.org:act:3FCE4329-1523-4546-92E7-C7BD15D5DEDF

Figs 1, 3I-L, 5B, 7E-F, 14

\section{Diagnosis}

See relevant sections of Z. saundersii, Z. josti sp. nov., and Z. warreni sp. nov. 


\section{Etymology}

This species is named to honor three generations of German-Brazilian naturalists: Carl Helmuth Theodor Mielke, Olaf Hermann Hendrik Mielke and Carlos Guilherme Costa Mielke. The specific epithet is a masculine noun in the genitive case.

\section{Type material examined}

\section{Holotype}

BRAZIL • \’; “/ Brasil, Espírito Santo, [Sooretama,] Res[erva]. Ecológica Sooretama, 1903'25”S 4008'50"W, 19-26-II-2013, Mielke \& Casagrande leg. // DZ 36.970 // BC-DZ Willmott 248 //”; DZUP.

\section{Paratypes $(3 \widehat{\partial}, 6$ 우)}

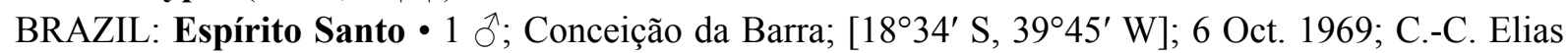

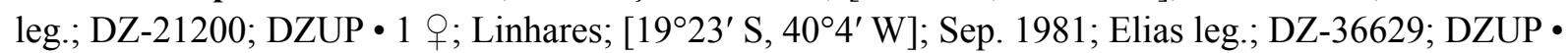
3 우 ㅎ S Sooretama, Reserva Ecológica de Sooretama; [19³'25" S, 408'50" W]; 100 m; 19-26 Feb. 2013; O.H.H. Mielke and M.M. Casagrande leg.; DZ-36618, DZ-36688, DZ-36968; DZUP• 1 \&; Santa Teresa,

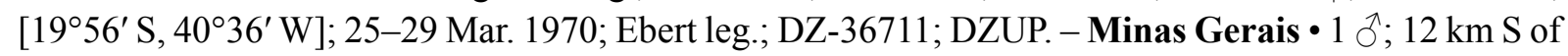
Teofilo Otoni; 600 m; 11 Feb. 2007; O.H.H. Mielke and M.M. Casagrande leg.; DZ-36599; DZUP. - Rio de Janeiro • 1 +; Nova Iguaçu, Fazenda São Bernardino; 19 Sep. 1937; R.F. d'Almeida leg.; DZ-36671; DZUP. - Not located • 1 ð̊; 'Brazil’; BMNH(E)-1205420; NHMUK.

\section{Description}

Male

FOREWING LENGTH. 24-25 mm $(\mathrm{n}=3)$.

HEAD. Eyes naked, with whitish scales at base; labial palpi laterally dark reddish brown with whitish scales, ventrally dark brown and whitish lines, first segment about the length of the third segment and as thick as the second, third segment thin, second segment thicker and almost four times the length of the third segment, with long hair-like scales; antennae reddish dark brown dorsally with whitish scales at the base of each segment, ventrally naked, approximately two-fifths the forewing length, with about 46 segments $(\mathrm{n}=5)$, distal segments forming a slender club.

THorax. Dorsally dark reddish brown; laterally and ventrally dark reddish brown with brownish gray scales.

LEGS. Foreleg brownish gray with whitish scales; mid and hindleg femur brownish gray with whitish scales, tibiae and tarsi mostly brownish gray with whitish scales ventrally, with pair of tibial spurs present at distal end of tibia.

ABDomen. Eighth tergite as stripe at base of eighth abdominal segment, in addition to presence of two distal broader patches.

Wing VENATION. Basal half of forewing Subcosta swollen; base of Cubitus swollen; forewing recurrent vein absent; origin of $M_{2}$ towards $M_{1}$ than $M_{3}$; hindwing humeral developed.

WING SHAPE. Forewing triangular, costal margin rounded, outer margin straight, inner margin more or less straight, apex and tornus rounded; hindwing more or less rounded, humeral area expanded, costal margin slightly rounded, outer margin slightly crenulated, inner margin slightly sinuous, apex and tornus rounded, not very conspicuous. 
DORSAL FOREWING. Ground color variable, usually dark reddish brown; marginal area and apex conspicuously darker brown.

DoRSAL HINDWING. Ground color similar to forewing; submarginal and marginal line somewhat visible though transparency along the costal margin, specially near the tornus.

Ventral fOREWING. Ground color brown, lighter than the dorsal forewing ground color; discal line reddish brown, noticeably fainter than other lines, running more or less obliquely from near the costal margin to 2A; postdiscal line dark reddish brown, variably developed in width, running obliquely from about $\mathrm{M}_{1}$ to $2 \mathrm{~A}$; submarginal line dark reddish brown, variably wavy, from the apex to the tornus along the outer margin, ending at about 2A; marginal line dark reddish brown, straight and narrower than submarginal line, from the apex to the tornus along the outer margin, ending at about $2 \mathrm{~A}$; fringe dark brown.

VentRAL hindwing. Ground color similar to forewing; discal line dark reddish brown, almost straight, running from costal to the inner margin; postdiscal line similar to and more or less parallel to discal line, passing through the end of the discal cell at the origin of $\mathrm{M}_{3}$, and posteriorly directed to the base of the wing at 2A-3A; submarginal band wavy, similar in color and width to the discal and postdiscal line, running from apex towards the tornus, occasionally fused with the posdiscal line near the costal margin and occasionally fused to the submedian line in 2A-3A; marginal line similar in color, but thinner than other lines, slightly wavy along the outer margin; submarginal ocelli from $\mathrm{M}_{1}$ to $2 \mathrm{~A}$, roughly oval, dark brown encircled by a marked orange ring and a subtler brown ring; pupil with scattered silver scales, ocelli at $\mathrm{M}_{2}-\mathrm{M}_{3}, \mathrm{M}_{3}-\mathrm{Cu}_{1}$, and $\mathrm{Cu}_{1}-\mathrm{Cu}_{2}$ similar in size, somewhat elongate, those in $\mathrm{M}_{1}-\mathrm{M}_{2}$ and $\mathrm{Cu}_{2}-2 \mathrm{~A}$ underdeveloped, usually half the size of the other ocelli; scales of the areas between postdiscal and submarginal lines and submarginal and marginal lines with variable light purple to lilac tinge; fringe dark brownish.

Genitalia (Fig. 5B). Tegumen somewhat flattened, anteriorly bulged, with a single dorsal dome-like projection near the base of the uncus; appendices angulares absent; uncus laterally flattened and straight, slightly longer than the length of the tegument in lateral view; brachia slightly shorter than the uncus, thicker at the base and narrowing to a point posteriorly; combination of ventral arms of the tegumen and dorsal arms of the saccus sinuous; saccus anterior projection tube-like, approximately the length of the tegumen; valva more or less triangular, stretched dorsal and posteriorly; basal half of valva larger, narrowing towards the apex, dorsal margin almost straight, ventral margin convex, apex broadly rounded; fultura inferior (i.e., juxta) strap-like; phallobase about one-third of phallus, rather straight; ductus ejaculatorius not discerned; aedeagus straight with manica covering approximately half, winglet absent, distal opening located ventrally where vesica is visible.

\section{Female}

ForEWING LENGTH. 26-27 mm $(\mathrm{n}=6)$.

Similar to male except as follows: foretarsus divided into five tarsomers; wings ground color generally lighter; forewing more rounded and broader, outer margin usually slightly convex; hindwing outer margin more crenulated; dorsal hindwing submarginal and marginal lines more noticeable seen through transparency.

Female abdomen and Genitalia (Fig. 7E-F): membranous areas between seventh and eight sternite folded forming the sclerotized antrum attached to the lamella antevaginalis near the ostium bursae; lamella antevaginalis sclerotized; lamella postvaginalis absent; eighth abdomen segment with a lateral sclerotized area; ductus bursae with a sclerotized area of about a third of its length near the ostium 
bursae; ductus seminalis origin close to the ostium bursae; corpus bursae oval, with a pair of parallel and dorsal signa, signa narrow and slightly shorter than the length of the corpus bursae.

\title{
Variation
}

The silvery blue patch between the median and submarginal lines in VHW can vary in intensity, and the coloration of the ocellar ring is also variable, being more yellowish in some specimens.

Distribution (Fig. 14)

This species is known to date from southeastern Brazil, from the states of Espírito Santo, Rio de Janeiro and Minas Gerais.

\section{Remarks}

Three barcoded specimens of Z. mielkeorum sp. nov. (BC-DZ-225, 248, 249) form a well supported clade $($ SH-aLRT/UF Boot $=99.8 / 95)$, with two individuals of $Z$. josti sp. nov. (MUSM-LEP-68763, 18704) (Fig. 1). Despite the small sampling size $(\mathrm{n}=5)$ for these two species, the existence of a 'barcoding gap' between these two taxa (see corresponding section of $Z$. jost $i$ sp. nov.), combined with the presence of wing pattern and genitalia differences that separate these two species, leads us to consider them as distinct species. The known ranges of these species are approximately $3000 \mathrm{~km}$ apart, reinforcing this taxonomic decision. In fact, no known area of sympatry exists between any species pair in the "saundersii clade", which thus appears to have undergone allopatric speciation. However, this taxonomic treatment will result in accepting Z. mielkeorum sp. nov. as a paraphyletic group. Although it is not an acceptable taxonomic practice to name non-monophyletic groups, we argue in this case based on the fact that $\mathrm{BC}$ DZ-249 is missing first 80 or so base pairs of its sequence. This missing information might have resulted in separation from the sequence generated from the individual from the same locality (BC-DZ-248, from Res. Ecologica Sooretama, Espírito Santo, Brazil) and, in fact, grouped together with BC-DZ-225, which is a specimen from a different site (Minas Gerais, Brazil). It is also worth noting that a number of butterfly species are recovered as paraphyletic, including species in some of the best studied butterfly genus Heliconius Kluk, 1780 (e.g., H. erato (Linnaeus, 1758) as in Kozak et al. 2015). Clearly, more data based on more individuals is needed in order to draw a firm conclusion as to taxonomic status of these two populations, and our treatment herein is a mere provisional hypothesis based on available information.

\author{
Zischkaia warreni Dias, Zacca \& Dolibaina, sp. nov. \\ urn:1sid:zoobank.org:act:F2CFEE62-2CC3-4FA5-BD05-D25F973A5691 \\ Figs 1, 3M-P, 5C, 7G-H, 14, 16C
}

\section{Diagnosis}

Zischkaia warreni sp. nov. is distinguished from other species in the "saundersii clade" by the absence of the VFW submedian line. Further distinctive characters include the rather prominent DHW submarginal and marginal line, reduced VHW ocellus in $\mathrm{M}_{1}-\mathrm{M}_{2}$ combined with the ocellus in $\mathrm{M}_{2}-\mathrm{M}_{3}$ being more than twice as large (in terms of diameter) and the median line and submarginal line being fused immediately after $2 \mathrm{~A}$ in males. Additional characters are also discussed in the relevant sections of other species.

\section{Etymology}

This specific epithet is in honor of our good friend, Andrew D. Warren, a prominent lepidopterist with a broad knowledge of butterflies. The specific epithet is to be considered a latinized masculine noun in the genitive case. 


\section{Type material examined}

\section{Holotype}

BRAZIL • đ'; “// 2-XI-2000, Represa Sanepar, Piraquara, PR [Paraná, Brazil], Bizarro leg. //DZ 36.948 //BC-DZ Willmott 227 //"; DZUP.

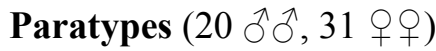

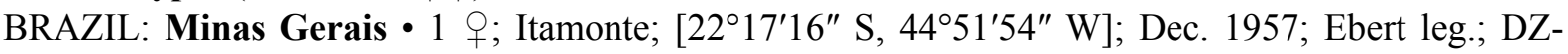

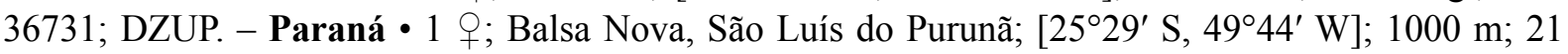

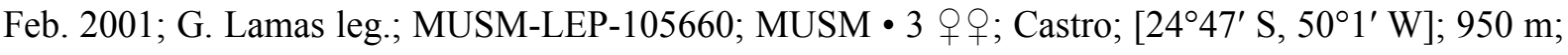
BMNH(E)-1718053 to BMNH(E)-1718054, BMNH(E)-1718064; NHMUK • 4 우, same collection data as for preceding; USNM -1 त, 1 क ; same collection data as for preceding; E.D. Jones leg.; BMNH(E)-1718069, BMNH(E)-1718061; NHMUK • 1 क; same collection data as for preceding but Sep. 1897; BMNH(E)-1718060; NHMUK • 1 क; Guarapuava, Serra da Esperança, N side BR 373,

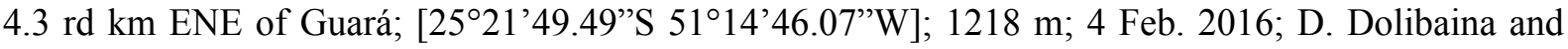

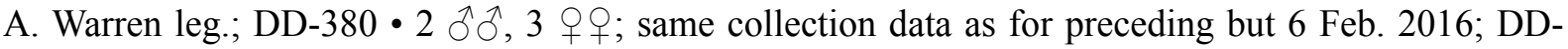

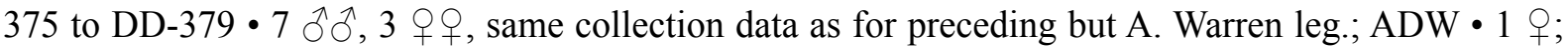

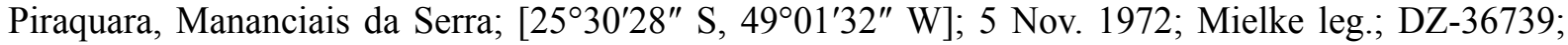

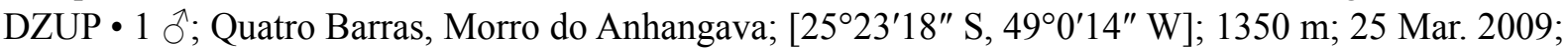
E. Carneiro leg.; DD-306 • 1 ते; same collection data as for preceding but D. Dolibaina leg.; DD-305 • 1 q; Tijucas do Sul; [255' S, 49 ${ }^{\circ} 12^{\prime} \mathrm{W}$ ]; 850 m; 13 Mar. 2004; G. Lamas leg.; MUSM-LEP-105659;

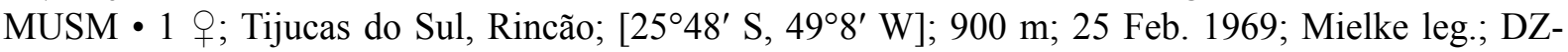
36719; DZUP • 1 §ิ, 1 क ; Tijucas do Sul, Vossoroca; 850 m; 20 Mar. 1971; Mielke leg.; DZ-21214, DZ-36669; DZUP • 2 $\widehat{\jmath}, 1$ 우 ; same collection data as for preceding but 8 Mar. 1972; DZ-36659, DZ-

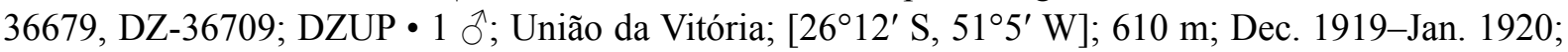
A. Hall leg.; BMNH(E)-10430703; NHMUK • 1 q; same collection data as for preceding; 750 m; 7 Nov. 1985; O.H.H. Mielke and M.M. Casagrande leg.; DZ-36749; DZUP. - Rio de Janeiro • 1 đ; Itatiaia, Serra Itatiaia, vertente SE; [22 $\left.19^{\prime} 55^{\prime \prime} \mathrm{S}, 44^{\circ} 36^{\prime} 38^{\prime \prime} \mathrm{W}\right]$; 1300 m; Feb. 1950; Ebert leg.; DZ36639; DZUP. - Santa Catarina • 1 q; Campo Alegre, Serra do Quiriri, [26 $6^{\circ} 34^{\prime \prime}$ S, 48 $59^{\prime} 2^{\prime \prime}$ W]; 1300 m; 14 Nov. 2009; O.H.H. Mielke, E. Carneiro and Melo leg.; DZ-36538; DZUP • 1 o; same collection data as for preceding but 14 Nov. 2009; O. Mielke and E. Carneiro; DD-304 1 ô, 1 क ;

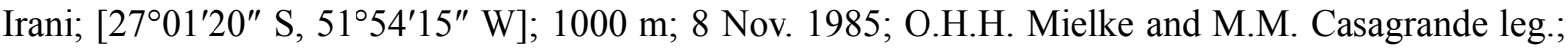

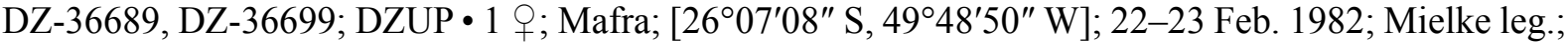

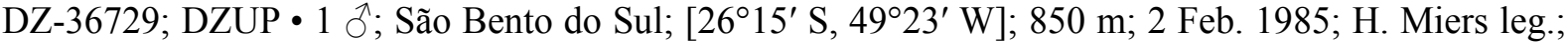

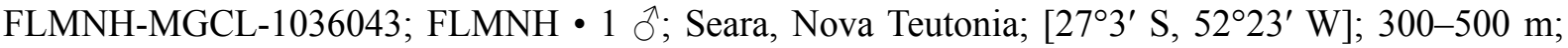
Feb. 1973; F. Plaumann leg.; FLMNH-MGCL-1036044; FLMNH. - São Paulo • 2 q ; ; Apiaí, Serra de Paranapiacaba; [2431' S, 4851' W]; Feb. 1972; Ebert leg.; DZ-36609, DZ-36653; DZUP. - Not located ・ 1 q; 'Brazil'; BMNH(E)-1205409; NHMUK.

\section{Description}

Male

FOREWING LENGTH. 24-25 mm $(\mathrm{n}=3)$.

HEAD. Eyes naked, with whitish scales at base; labial palpi first segment with white and brownish long hair-like scales; second segment length almost twice as great as eye depth and covered with brown scales and hair-like scales laterally, with white scales and hair-like scales, dorsally with pale brownish long hair-like scales, ventrally with black and white hair-like scales, about 3-4 times as long as segment width; third segment about one-fourth of second segment in length and covered with black scales and hair-like scales, with slight patch of creamy-white scales laterally; antennae approximately two-fifth of forewing length, with ca 37 segments $(n=1)$, distal ca 15 composing club, club not prominent. 
THORAX. Dorsally, laterally and ventrally scattered with brownish gray scales.

LEGS. Foreleg brownish, foretarsus and tibia similar in length, femur not examined; midleg and hindleg with femur creamy white ventrally, tibia and tarsus grayish dorsally, whitish to ocher ventrally, tarsus and tibia spined ventrally, and a pair of tibial spurs at distal end of tibia.

AвDomen. Eighth tergite as stripe at base of eighth abdominal segment, in addition to presence of two distal broader patches.

Wing VENATION. Basal half of forewing Subcosta swollen; base of Cubitus swollen; forewing recurrent vein absent; origin of $M_{2}$ towards $M_{1}$ than $M_{3}$; hindwing humeral developed.

WING SHAPE. Forewing subtriangular, apex rounded, costal margin convex, outer margin slightly convex (almost straight), inner margin straight, but rounded towards thorax near base; hindwing slightly elongate, rounded, costal margin almost straight, angled towards thorax near base, outer margin slightly undulating, inner margin slightly concave near tornus, anal lobe convex, slightly round.

DORSAL FOREWING. Ground color brownish, distally darker; androconial scales absent; trace of submarginal band indistinct.

DoRSAL HINDWING. Ground color similar to forewing, trace of submarginal and marginal band visible.

VeNTRAL FOREWING. Ground color light grayish brown, area below 2A paler; submedian line invisible; dark-brown narrow median line, extends from Radius to $2 \mathrm{~A}$, traversing wing outward with terminal end of median line almost reaching submarginal line; concolorous submarginal line extending from apex towards tornus, terminating around 2A; concolorous marginal line, narrower than submarginal line, extending from apex towards tornus, but terminates around $2 \mathrm{~A}$; fringe dark brownish.

VENTRAL HINDWING. Ground color similar to forewing; regular dark-brown submedian line somewhat sigmoid, extending from costa to inner margin, terminal end curving basally along inner margin; median line almost parallel to submedian line, concolorous, similar in width, passing origin of $\mathrm{M}_{3}$, posterior and anterior end fused with submarginal line in 2A-3A and Rs- $\mathrm{M}_{1}$ respectively; submarginal line extending from apex towards tornus, anterior and posterior end fused with median line in Rs- $\mathrm{M}_{1}$, jagged, posterior end slightly broadening and fused to median line in 2A-3A; marginal line, concolorous, undulate along outer margin, much thinner than submarginal line; submarginal ocelli from $\mathrm{M}_{1}$ to $2 \mathrm{~A}$, roughly oval, pupil as silver scales placed distally, black central spot ringed with orangish ring then with thin dark brownish indistinct ring, those in $\mathrm{M}_{2}-\mathrm{M}_{3}$ and $\mathrm{M}_{3}-\mathrm{Cu}_{1}$ are both similar in size, those in $\mathrm{M}_{1}-\mathrm{M}_{2}$ and $\mathrm{Cu}_{2}-2 \mathrm{~A}$ smaller, especially ocellus in $\mathrm{M}_{1}-\mathrm{M}_{2}$ reduced, ocellus in $\mathrm{Cu}_{1}-\mathrm{Cu}_{2}$ largest; fringe dark brownish.

Genitalia (Fig. 5C). Tegumen somewhat rounded in lateral view, dorsally curved in lateral view, domeshaped hump present posteriorly along dorsal margin; combination of ventral arms from tegumen and dorsal arms from saccus almost straight; appendices angulares present but rather inconspicuous; saccus shorter than uncus in length; uncus long and narrow, about twice as long as tegumen in length, with sparse hair-like setae, slightly hooked at posterior end; brachia long and narrow, shorter than uncus in length; fultura inferior (i.e., juxta) present as developed plate in posterior view; valva setose, basal half of valva roughly trapezoidal in lateral view, ventral margin convex in middle, dorsal margin almost straight except for margin basal to costa angles down to meet ventral margin, distal half narrow and somewhat elongate with rounded apex; costa subtriangular in lateral view, projecting towards appendices angulares; phallobase about one-third of phallus, rather straight; ductus ejaculatorius coming out higher than anterior end of coecum; aedeagus straight with manica covering approximately half, winglet absent, distal opening located ventrally where vesica is visible. 
Female

FOREWING LENGTH. 26-27 mm $(\mathrm{n}=6)$.

Similar to male except as follows: foretarsus first and second subsegments apparently fused; forewing more rounded and broad; ground color of both wing surfaces paler, posterior end of VFW discal line do not come close to submarginal line as in male. VHW area between postdiscal and submarginal line whitish (around ocelli).
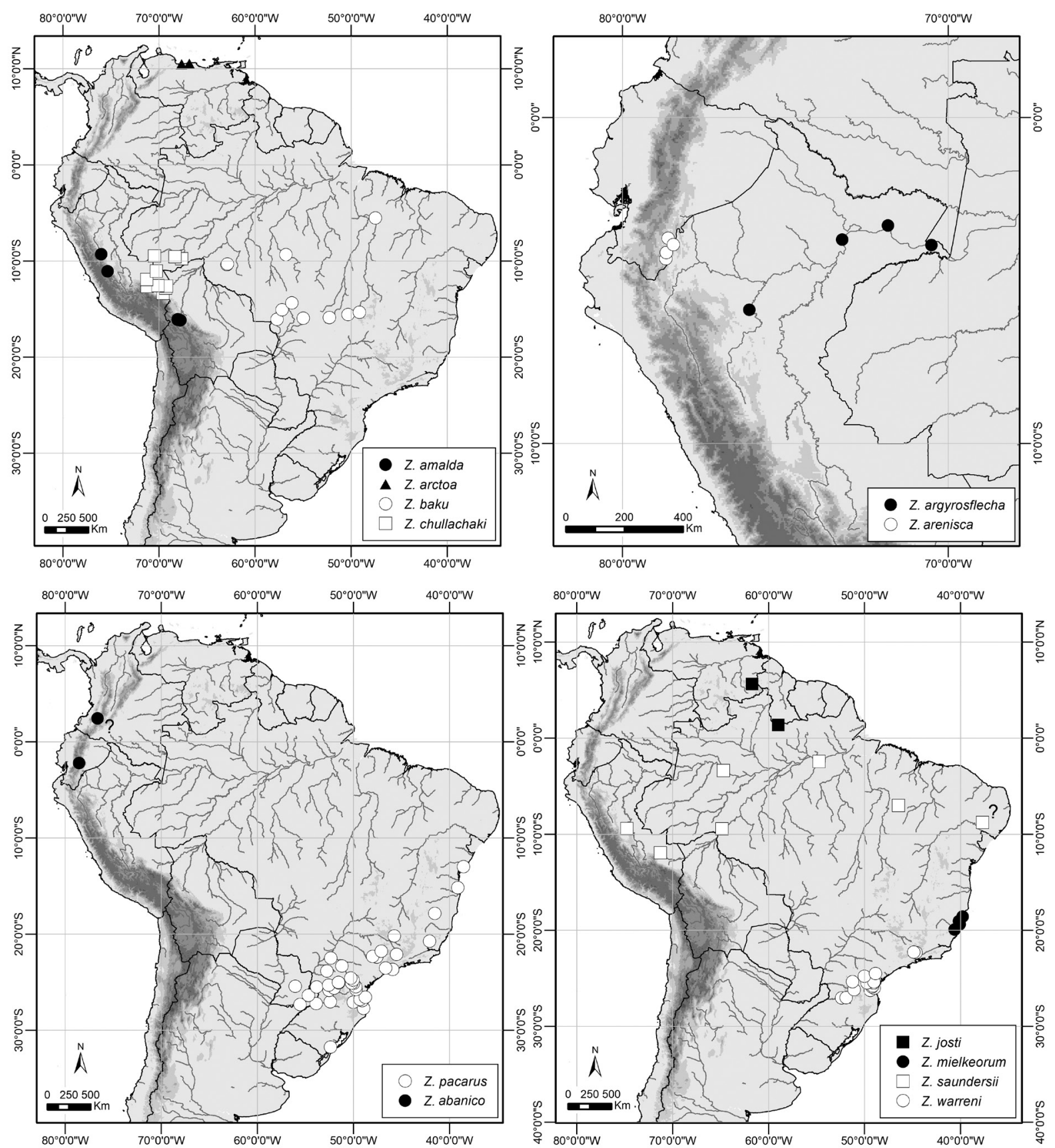

Fig. 14. Distribution maps for taxa of Zischkaia Forster, 1964. 
Female ABdomen AND Genitalia (Fig. 7G-H): inter-segmental membrane between seventh and eighth tergite not pleated, but expanded with posterior edge forming a smooth, curving sclerotized band anterior to ostium bursae that seamlessly borders the broad, sclerotized plate of lamella antevaginalis, which narrows ventrally to encircle ostium bursae and is indented throughout with the edges forming raised lip; eighth abdominal segment lateral side with sclerotized plate and with spiracle near dorsal margin, ventrally connected to lamella antevaginalis as sclerotized stripe, fused below ostium bursae as 'arm'; ductus bursae membranous; origin of ductus seminalis close to ostium bursae; corpus bursae roughly oval in dorsal view, extending to third abdominal segment, with two signa in middle, parallel to each other.

\section{Variation}

The VFW submarginal and marginal lines are more or less fused in cell $\mathrm{Cu}_{2}$ in some specimens, whereas they are placed rather further apart in other specimens.
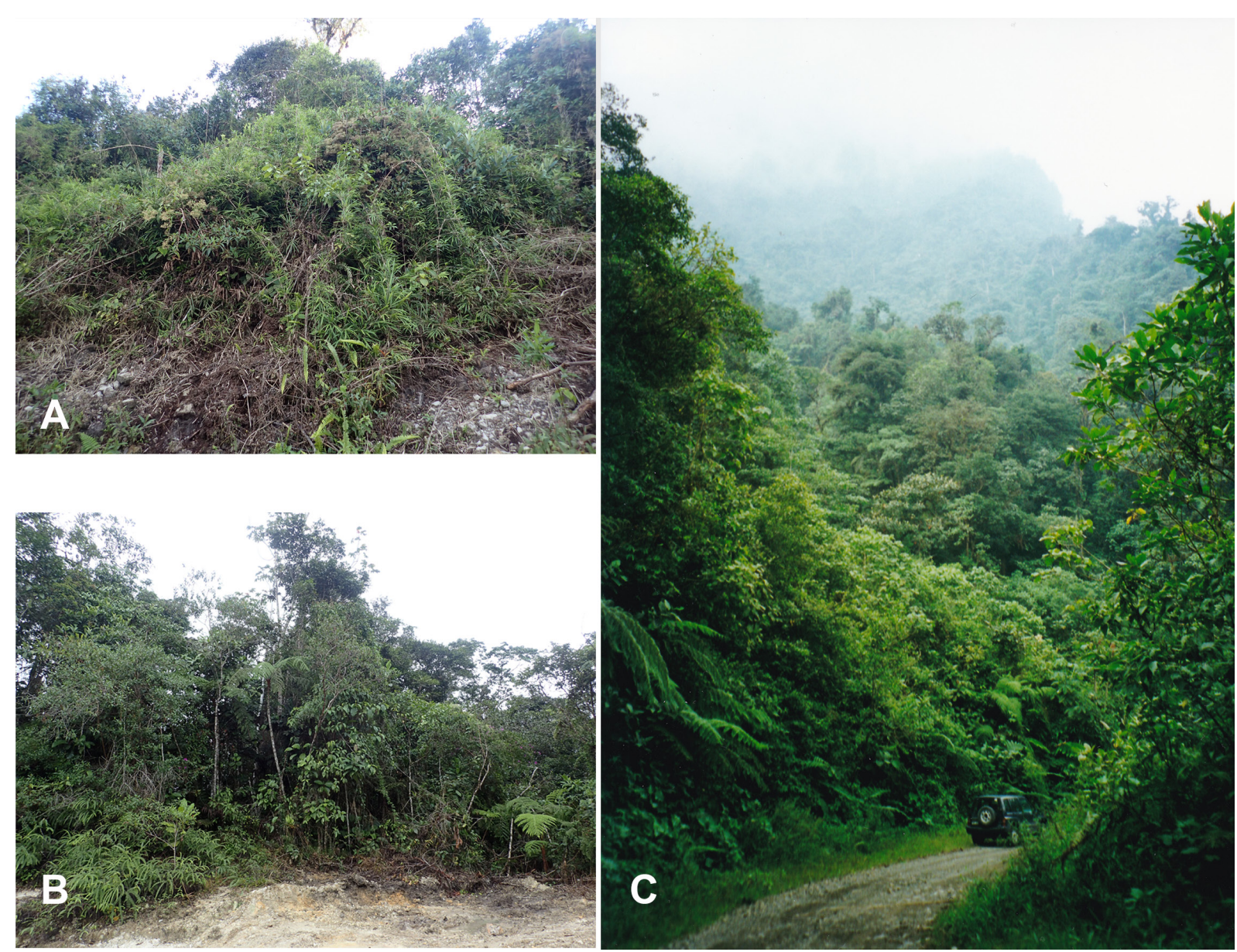

Fig. 15. Habitats of species of Zischkaia Forster, 1964. A. Climbing bamboo species (Poaceae, likely Chusquea Kunth) that was common along the Sumak Yaku mine track, Zamora-Chinchipe, Ecuador, where Z. arenisca Nakahara, Willmott \& Hall, sp. nov. was common (photo by Keith Willmott). B. Ridge top at San Roque ridge, Zamora-Chinchipe, Ecuador, where females of Z. arenisca sp. nov. were found (photo by Keith Willmott). C. View of the ridge line $500 \mathrm{~m}$ west of the Río Abanico (Morona-Santiago, Ecuador) collecting site (photo by Andrew Neild). 


\section{Distribution (Fig. 14)}

This species is known to date from southeastern to southern Brazil, in the states of Rio de Janeiro, Minas Gerais, São Paulo, Paraná and Santa Catarina. The geographic distribution of Z. warreni sp. nov. is apparently confined to areas associated with plateaus with Araucaria forest in middle to high elevations
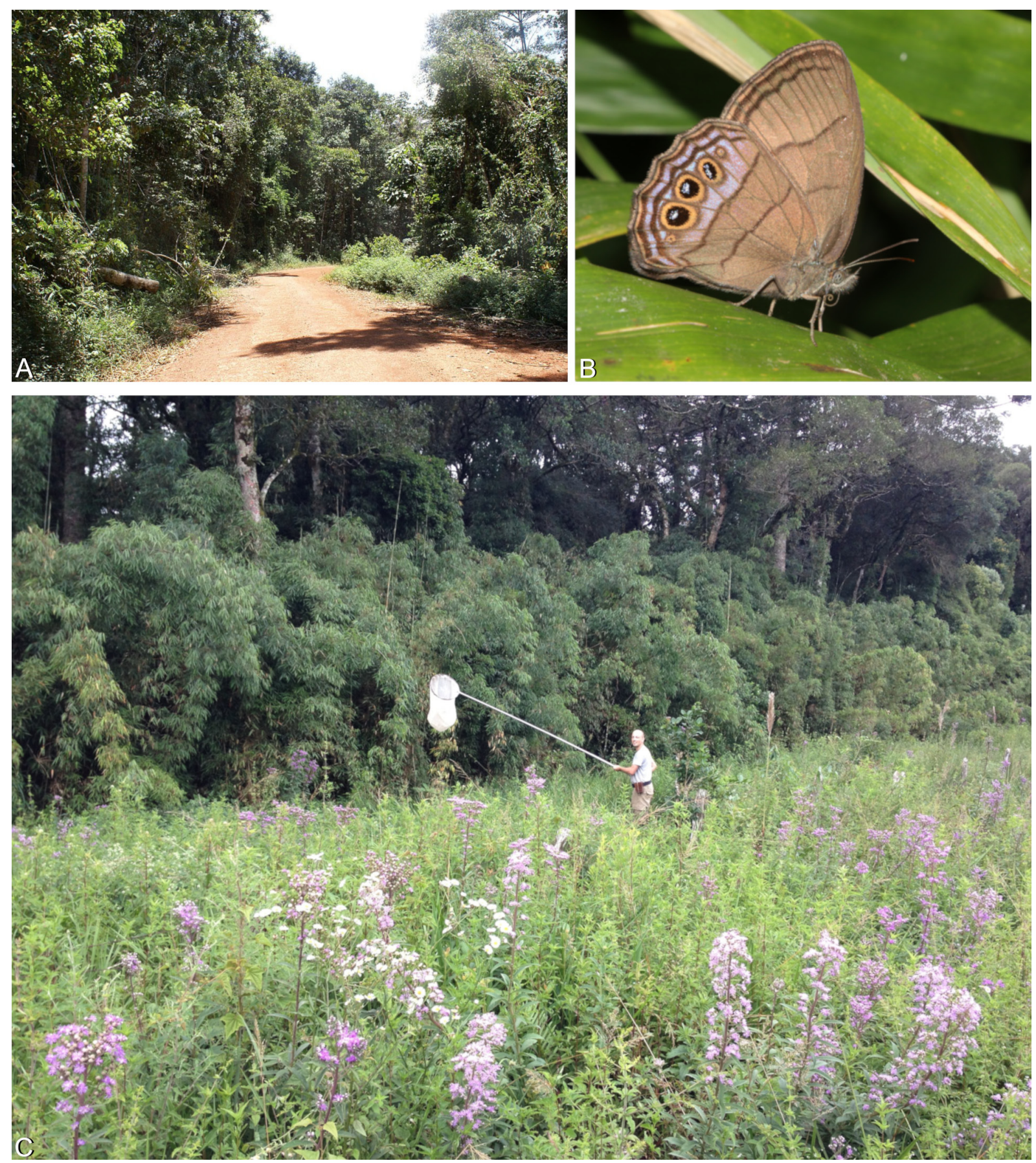

Fig. 16. Habitats of species of Zischkaia Forster, 1964. A. Habitat at the type locality of Z. josti Nakahara \& Kleckner, sp. nov., Kavanayen, Venezuela (photo by Bernhard Jost). B. Adult in situ at Serra da Esperança, Guarapuava, Paraná, Brazil (photo by Andrew Warren). C. Habitat of $Z$. warreni Dias, Zacca \& Dolibaina, sp. nov., Serra da Esperança, Guarapuava, Paraná, Brazil (photo by Andrew Warren). 
of southern Brazil, not extending beyond Serra Geral in the west. This distributional pattern is distinct from its potentially sympatric species $Z$. pacarus, which is also found in low elevation areas in the Paraná drainage and in the Atlantic coastal zone.

\section{Remarks}

The evidence from molecular data (see Fig. 1 and Table 4) and morphological distinctiveness documented above leaves no doubt as to its specific status. Adults of $Z$. warreni sp. nov. are similar in behavior to Z. pacarus, flying in association with the bamboo Merostachys (Poaceae: Bambusoideae) (Fig. 16A, C). The males' flight is faster than that of the females, and individuals are commonly found engaged in patrolling flight. Both sexes are never found away from the bamboo and they are more active between the middle of the morning and the beginning of the afternoon. The restricted habitat of $Z$. warreni sp. nov. in Araucaria forests suggests that they likely use Merostachys as the caterpillar host plant.

\section{Discussion}

Our species-level review of Zischkaia based on morphology and molecular data increased the speciesrichness of the genus by adding nine species named and described above. Despite two distinctive and morphologically diagnosable clades recognized in Zischkaia ("pacarus clade" and "saundersii clade"), species within these two clades are rather similar in terms of wing pattern and genitalia. For example, $Z$. pacarus and Z. abanico sp. nov. are easily distinguished from the other species in the "pacarus clade" based on the shape of the apical process of the valva, but the male genitalia of these two species (Z. pacarus and Z. abanico sp. nov.) and the rest of the species in the clade are highly homogenous where interspecific difference either does not exist or rather subtle even if present. A similar case of genitalia homogeneity among species is reported in other euptychiine species-groups, such as Euptychia "audacia clade" and Forsterinaria "boliviana clade" (Peña \& Lamas 2005; Nakahara et al. 2017). This observed morphological homogeneity combined with the lack of DNA 'barcodes' data for four species in the "pacarus clade" may lead to a discussion as to the conspecificy of some taxa, in particular, Z. amalda, Z. arctoa sp. nov., Z. baku sp. nov. and Z. chullachaki sp. nov. (barcoding data available for only $Z$. chullachaki sp. nov.). However, we argue against this by their allopatric distribution and apparent difference in elevational zone where they occur (Z. amalda and Z. arctoa sp. nov. being montane; Z. baku sp. nov. and Z. chullachaki sp. nov. being lowland species), in addition to subtle morphological differences between these taxa discussed in relevant sections of those species above. Nevertheless, the lack of DNA sequence data for Z. amalda, Z. arctoa sp. nov. and Z. baku sp. nov. hinders further investigation of their taxonomic status, as well as their relationships to determine pairs of sister taxa. As with species in the "saundersii clade", the known geographic range of taxa in the "pacarus clade" suggests they followed allopatric speciation. Thus, determining sister species pairs in the "pacarus clade" will enable us to test if speciation across an elevational gradient (i.e., vertical speciation, as in Chapman 1917) occurred in this group or not, to further assess the taxonomic status of these poorly known elements of the Neotropical butterfly fauna.

\section{Author contributions}

SN prepared the first draft of the manuscript, which was read and commented on by all authors. The morphological study and preparation of relevant figures were performed by SN, TZ, FMSD and DRD. The molecular lab work, including the analysis, was conducted by SN, KK and LX. SN, TZ, FMSD, DRD, ME, MMC, OHHM, GL, BH and KW contributed towards compiling specimen data, including gathering tissue samples mainly done by SN, ME and KW. Finally, Jean-Claude Petit, Lee D. Miller (deceased) and Jason Hall co-authored new species described and named in this article thanks to their contributions to collecting key material or to developing species descriptions. 


\section{Acknowledgements}

We are grateful to Jean-Claude Petit, André V.L. Freitas, Axel Hausmann, Bernhard Jost, Andrew Warren, Renato de Oliveira Silva, Marcelo Duarte, Ruedi Bryner, Brian Harris, Robert Robbins, Donald Harvey, David Grimaldi, Christine Lebeau and the Romero family for allowing access to the specimens of Zischkaia under their care. We extend our thanks to Andrew Neild for sharing information regarding Venezuelan Zischkaia, providing a photo of Río Abanico used in this article and translating Latin text; James Hayden for translating German text; Ulf Buchsbaum for kindly loaning material to SN for study; Sebastián Padrón and Erick Rodríguez for help with the Spanish translation. Thanks are also due to Eduardo Barbosa for providing us with information on the provenance of the name 'baku'. We thank Brooke Patrusky, Karunakar Kallam, Lindsay Richards, Stephanie Tyler and Sarah Nguyentran for their work in the McGuire Center molecular lab. We thank Chris Jiggins, Julia Robinson Willmott and Jamie Robinson Willmott for collecting important specimens of Zischkaia in Ecuador. Field work by KRW and SN in Ecuador was done under the permit 'Genetic Diversity of Ecuador' (MAE-DNB-CM-2016-0045), granted by the Ministerio del Ambiente of Ecuador to the National Institute of Biodiversity (INABIO), which supports the project 'Diversity and Biology of the Lepidoptera of Ecuador'. We acknowledge the National Science Foundation (Grant No. DEB-1256742) for support. SN acknowledges the University of Florida's Department of Entomology and Nematology for support; TZ thanks FAPESP for a Post-Doc fellowship (2017/02264-6). FMSD, DRD and OHHM would like to thank members of the Laboratório de Estudos em Lepidoptera Neotropical (LELN-UFPR) for additional help; and the Conselho Nacional de Desenvolvimento Científico e Tecnológico $(\mathrm{CNPq})$ for the research fellowship granted to the authors (FMSD: 150670/2018-4; DRD: 171177/2017-7; OHHM: 304639/2014-2). Brazilian specimens used in this study are registered at the Sistema Nacional de Gestão do Patrimônio Genético e do Conhecimento Tradicional Associado (SisGen) (\#A35372).

\section{References}

Austin G.T. \& Mielke O.H.H. 2008. Hesperiidae of Rondônia, Brazil: Porphyrogenes Watson (Lepidoptera: Pyrginae: Eudamini), with descriptions of new species from Central and South America. Insecta Mundi 44: 1-56.

Barbosa E.P., Silva A.K., Paluch M., Azeredo-Espin A.M.L. \& Freitas A.V.L. 2015. Uncovering the hidden diversity of the Neotropical butterfly genus Yphthimoides Forster (Nymphalidae: Satyrinae): description of three new species based on morphological and molecular data. Organisms Diversity and Evolution 15 (3): 577-589. https://doi.org/10.1007/s13127-015-0221-y

Beccaloni G.W., Viloria Á.L., Hall S.K. \& Robinson G.S. 2008. Catalogue of the Hostplants of the Neotropical Butterflies. Catálogo de las Plantas Huésped de las Mariposas Neotropicales. Monografías del Tercer Milenio 8. Sociedad Entomológica Aragonesa, Zaragoza.

Bland K.P. 2019. Name-bearing types of butterflies (Lepidoptera, Papilionoidea), in the National Museums of Scotland, Edinburgh. Zootaxa 4559 (1): 57-89. https://doi.org/10.11646/zootaxa.4559.1.2

Brown K.S. 1992. Borboletas da Serra do Japi: Diversidade, hábitats, recursos alimentares e variação temporal. In: Morellato L.P.C. (ed.) História natural da Serra do Japi. Ecologia e Preservação de uma Área florestal no Sudeste do Brasil: 142-187. Campinas, Editora da Unicamp/Fapesp.

Brown K.S. \& Freitas A.V.L. 2000. Diversidade de Lepidoptera em Santa Teresa, Espírito Santo. Boletim do Museu de Biologia Mello Leitão (N.S.) 11/12: 71-116.

Butler A.G. 1867a. A monograph of the genus Euptychia, a numerous race of butterflies belonging to the family Satyridae; with descriptions of sixty species new to science, and notes to their affinities, etc. Proceedings of the Zoological Society of London 1866 (3): 458-504. 
Butler A.G. 1867b. Descriptions of some new species of Satyridae belonging to the genus Euptychia. Proceedings of the Zoological Society of London 1867 (1): 104-110.

Butler A.G. 1868. Catalogue of Diurnal Lepidoptera of the Family Satyridae in the Collection of the British Museum. Taylor and Francis, London.

Butler A.G. 1877. On new species of the genus Euptychia, with a tabular view of those hitherto recorded. Journal of the Linnean Society of London (Zoology) 13 (67): 116-128.

https://doi.org/10.1111/j.1096-3642.1877.tb02375.x

Carneiro E., Mielke O.H.H. \& Casagrande M.M. 2008. Borboletas do sul da ilha de Santa Catarina, Florianópolis, Santa Catarina, Brasil (Lepidoptera: Hesperioidea e Papilionoidea). Shilap 36 (142): 261-271.

Chapman F.M. 1917. The distribution of bird life in Colombia. Bulletin of the American Museum of Natural History 31: 1-169.

Comstock J.H. \& Needham J.G. 1898. The wings of insects. American Naturalist 32 (373): 43-48.

Cong Q. \& Grishin N.V. 2014. Anew Hermeuptychia (Lepidoptera, Nymphalidae, Satyrinae) is sympatric and synchronic with $H$. sosybius in southeast US coastal plains, while another new Hermeuptychia species - not hermes - inhabits south Texas and northeast Mexico. ZooKeys 379: 43-91.

https://doi.org/10.3897/zookeys.379.6394

D’Abrera B. 1988. Butterflies of the Neotropical Region. Part V. Nymphalidae (Conc.) \& Satyridae: 679-877. Black Rock, Hill House, Victoria.

Dolibaina D.R., Mielke O.H.H. \& Casagrande M.M. 2011. Borboletas (Papilionoidea e Hesperioidea) de Guarapuava e arredores, Paraná, Brasil: um inventário com base em 63 anos de registros. Biota Neotropica 11 (1): 341-354. https://doi.org/10.1590/S1676-06032011000100031

Edgar R.C. 2004. MUSCLE: multiple sequence alignment with high accuracy and high throughput. Nucleic Acids Research 32 (5): 1792-1797. https://doi.org/10.1093/nar/gkh340

Elias M., Hill R., Willmott K.R., Dasmahapatra K., Brower A., Mallet J. \& Jiggins C. 2007. Limited performance of DNA barcoding in a diverse community of tropical butterflies. Proceedings of the Royal Society of London B 274: 2881-2889. https://doi.org/10.1098/rspb.2007.1035

Emery E.O., Brown Jr. K.S. \& Pinheiro C.E.G. 2006. As borboletas (Lepidoptera, Papilionoidea) do Distrito Federal, Brasil. Revista Brasileira de Entomologia 50 (1): 85-92.

https://doi.org/10.1590/S0085-56262006000100013

Espeland M., Breinholt J., Barbosa E., Casagrande M.M., Huertas B., Lamas G., Marín M. A., Mielke O.H.H., Miller J.Y., Nakahara S., Tan D., Warren A.D., Zacca T., Kawahara A., Freitas A.V.L. \& Willmott K.R. 2019. Four hundred shades of brown: higher level phylogeny of the problematic Euptychiina (Lepidoptera, Nymphalidae, Satyrinae) based on hybrid enrichment data. Molecular Phylogenetics and Evolution 131: 116-124. https://doi.org/10.1016/j.ympev.2018.10.039

Forster W. 1964. Beiträge zur Kenntnis der Insektenfauna Boliviens XIX Lepidoptera III. Satyridae. Veröffentlichungen der Zoologischen Staatssammlung München 8: 51-188.

Freitas A.V.L., Barbosa E.P., Zacca T., Marín M.A., Beirão M.V., Silva A.R.M., Casagrande M.M., Espeland M. \& Willmott K.R. 2018. Before it is too late: description of a new genus and species of butterfly from a highly threatened Brazilian biome. Revista Brasileira de Entomologia 62: 148-158. https://doi.org/10.1016/j.rbe.2018.02.003

Gaede M. 1931. Familia Satyridae. Lepidopterorum Catalogus 43: 1-320; 46: 321-544; 48: 545-759.

GIMP team 2016. GIMP-GNU Image Manipulation Program.

Available from https://www.gimp.org [accessed Jun. 2016]. 
Godart J.B. [1824]. In: Latreille P.A. \& Godart J.B. (eds) Encyclopédie méthodique. Histoire naturelle. Entomologie, ou Histoire naturelle des Crustacés, des Arachnides et des Insectes: 329-828. Veuve Agasse, Paris.

Grimshaw P.H. 1897. On some type specimens of Lepidoptera and Coleoptera in the Edinburgh Museum of Science and Art. Transactions of the Royal Society of Edinburgh 39 (1): 1-11.

Guindon S., Dufayard J-F., Lefort V., Anisimova M., Hordijk W. \& Gascuel O. 2010. New algorithms and methods to estimate maximum-likelihood phylogenies: assessing the performance of PhyML 3.0. Systematic Biology 593: 307-321. https://doi.org/10.1093/sysbio/syq010

Hoang D.T., Chernomor O., von Haeseler A., Minh B.Q. \& Vinh L.S. 2018. UFBoot2: Improving the ultrafast bootstrap approximation. Molecular Biology and Evolution 35: 518-522.

https://doi.org/10.1093/molbev/msx281

Horn W., Kahle I., Friese G. \& Gaedike R. 1990. Collectiones entomologicae. Ein Kompendium über den Verbleib entomologischer Sammlungen der Welt bis 1960. Teil I: A bis K. Akademie der Landwirtschaftswissenschaften der Deutschen Demokratischen Republik, Berlin.

ICZN (International Commission on Zoological Nomenclature) 1999. International Code of Zoological Nomenclature, $4^{\text {th }}$ Edition. International Trust for Zoological Nomenclature, London.

Kalyaanamoorthy S., Minh B.Q., Wong T.K.F., von Haeseler A. \& Jermiin L.S. 2017. ModelFinder: Fast Model Selection for Accurate Phylogenetic Estimates. Nature Methods 14: 587-589. https://doi.org/10.1038/nmeth.4285

Kirby W.F. 1871. A Synonymic Catalogue of Diurnal Lepidoptera. John Van Voorst, London.

Kirby W.F. 1879. Catalogue of the Collection of Diurnal Lepidoptera Formed by the Late William Chapman Hewitson of Oatlands, Walton-on-Thames; and Bequeathed by him to the British Museum. John Van Voorst, London.

Klots A.B. 1956. Lepidoptera. In: Tuxen S.L. (ed.) Taxonomist's Glossary of Genitalia in Insects: 97111. Munksgaard, Copenhagen.

Kozak K.M., Wahlberg N., Neild A.F., Dasmahapatra K.K., Mallet J. \& Jiggins C.D. 2015. Multilocus species trees show the recent adaptive radiation of the mimetic Heliconius butterflies. Systematic Biology 64 (3): 505-524. https://doi.org/10.1093/sysbio/syv007

Lamas G. 1994. Butterflies of the Explorer's Inn Reserve. In: Foster R.B., Carr J.L. \& Forsyth A.B. (eds) The Tambopata-Candamo Reserved Zone of Southeastern Perú: A Biological Assessment: 62-63, 162-177. RAP Working Papers 6, Conservation International.

Lamas G. 1997. Lepidoptera of the Cordillera del Cóndor. In: Schulenberg T.S. \& Awbrey K. (eds) The Cordillera del Cóndor Region of Ecuador and Peru: A Biological Assessment: 90-98, 212-230. RAP Working Papers 7, Conservation International.

Lamas G. 2004. Nymphalidae. Satyrinae. Tribe Satyrini. Subtribe Euptychiina In: Lamas G. (ed.) Checklist: Part 4A. Hesperioidea-Papilionoidea.In:Heppner J.B.(ed.), Atlas of Neotropical Lepidoptera. Volume 5A: 217-223. Association for Tropical Lepidoptera, Scientific Publishers, Gainesville.

Lamas G. \& Grados J. [1997]. Mariposas de la Cordillera del Sira, Peru. Revista Peruana de Entomología 39: 55-61.

Lamas G., Robbins R.K. \& Harvey D.J. 1991. A preliminary survey of the butterfly fauna of Pakitza, Parque Nacional del Manu, Peru, with an estimate of its species richness. Publicaciones del Museo de Historia Natural 40, Universidad Nacional Mayor de San Marcos. 
Marín M.A., Peña C., Freitas A.V.L., Wahlberg N. \& Uribe S.I. 2011. From the phylogeny of the Satyrinae butterflies to the systematics of Euptychiina (Lepidoptera: Nymphalidae): history, progress and prospects. Neotropical Entomology 40: 1-13. https://doi.org/10.1590/S1519-566X2011000100001

Mielke C.G.C. 1995. Papilionoidea e Hesperioidea (Lepidoptera) de Curitiba e seus arrededores, Paraná, Brasil, com notas taxonômicas sobre Hesperiidae. Revista Brasileira de Zoologia 11 (4): 759-776. https://doi.org/10.1590/S0101-81751994000400018

Mielke O.H.H. \& Casagrande M.M. 1998. Papilionoidea e Hesperioidea (Lepidoptera) do Parque Estadual do Morro do Diabo, Teodoro Sampaio, São Paulo, Brasil. Revista Brasileira de Zoologia 14 (4): 967-1001. https://doi.org/10.1590/S0101-81751997000400013

Mielke O.H.H., Carneiro E. \& Casagrande M.M. 2010. Lepidopterofauna (Papilionoidea e Hesperioidea) do Parque Estadual do Chandless e arredores, Acre, Brasil. Biota Neotropica 10 (4): 285-299. https://doi.org/10.1590/S1676-06032010000400033

Miller L.D. 1968. The Higher Classification, Phylogeny and Zoogeography of the Satyridae (Lepidoptera). Memoirs of the American Entomological Society 24. The American Entomological Society, Philadelphia.

Miller L.D. 1970. Nomenclature of wing veins and cells. Journal of Research on the Lepidoptera 8 (2): $37-48$.

Monteiro A. \& Pierce N. 2001. Phylogeny of Bicyclus (Lepidoptera: Nymphalidae) inferred from COI, COII and EF1a gene sequences. Molecular Phylogenetics and Evolution 18: 264-281. https://doi.org/10.1006/mpev.2000.0872

Muschamp P.A.H. 1915. The ci-devant genus Epinephele. Entomologist's Record and Journal of Variation 27: 152-156.

Nakahara S., Hall J.P.W., Lamas G. \& Willmott K.R. 2015a. Seven new species and one new subspecies of Euptychia Hübner, 1818 (Lepidoptera: Nymphalidae: Satyrinae) from the tropical Andes. Tropical Lepidoptera Research 25 (2): 63-79.

Nakahara S., Janzen D.H., Hallwachs W. \& Espeland M. 2015b. Description of a new genus for Euptychia hilara C. Felder \& R. Felder, 1867 (Lepidoptera, Nymphalidae, Satyrinae). Zootaxa 4012 (3): 525-541. https://doi.org/10.11646/zootaxa.4012.3.7

Nakahara S., Barbosa E.P. \& Freitas A.V.L. 2017. A potentially endangered new species of Euptychia Hübner, 1818 (Lepidoptera: Nymphalidae: Satyrinae) from the Atlantic coastal forest of Brazil. Neotropical Entomology 46 (3): 302-309. https://doi.org/10.1007/s13744-016-0466-y

Nakahara S., McDonald J., Delgado F. \& Padrón S.P. 2018a. Discovery of a rare and striking new pierid butterfly from Panama (Lepidoptera: Pieridae). Zootaxa 4527 (2): 281-291.

https://doi.org/10.11646/zootaxa.4527.2.9

Nakahara S., Willmott K.R., Mielke O.H.H., Schwartz J., Zacca T., Espeland M. \& Lamas G. 2018b. Seven new taxa from the butterfly subtribe Euptychiina (Lepidoptera: Nymphalidae: Satyrinae) with revisional notes on Harjesia Forster, 1964 and Pseudeuptychia Forster, 1964. Insecta Mundi 0639: 1-38.

Nakahara S., Zacca T., Huertas B., Neild A.F.E., Hall J.P.W., Lamas G., Holian L.A., Espeland M. \& Willmott K.R. 2018c. Remarkable sexual dimorphism, rarity and cryptic species: a revision of the "aegrota species group" of the Neotropical butterfly genus Caeruleuptychia Forster, 1964 with the description of three new species (Lepidoptera, Nymphalidae, Satyrinae). Insect Systematics and Evolution 49 (2): 130-182. https://doi.org/10.1163/1876312X-00002167

Nakahara S., Lamas G., Tyler S., Marín M.A., Huertas B., Willmott K.R., Mielke O.H.H. \& Espeland M. 2019. A revision of the new genus Amiga Nakahara, Willmott \& Espeland gen. n., described for 
Papilio arnaca Fabricius, 1776 (Lepidoptera: Nymphalidae: Satyrinae). ZooKeys, 821: 85-152. https://doi.org/10.3897/zookeys.821.31782

Nguyen L-T., Schmidt H.A., von Haeseler A. \& Minh B.Q. 2015. IQ-TREE: A fast and effective stochastic algorithm for estimating maximum likelihood phylogenies. Molecular Biology and Evolution 32: 268-274. https://doi.org/10.1093/molbev/msu300

Peña C. \& Lamas G. 2005. Revision of the butterfly genus Forsterinaria Gray, 1973 (Lepidoptera: Nymphalidae, Satyrinae). Revista peruana de Biología 12 (1): 5-48.

https://doi.org/10.6084/M9.FIGSHARE.96638

Peña C., Nylin S., Freitas A.V.L. \& Wahlberg N. 2010. Biogeographic history of the butterfly subtribe Euptychiina (Lepidoptera, Nymphalidae, Satyrinae). Zoologica Scripta 39 (3): 243-258.

https://doi.org/10.1111/j.1463-6409.2010.00421.x

Riley N.D. \& Gabriel A.G. 1924. Catalogue of the Type Specimens of Lepidoptera Rhopalocera in the British Museum. Part I. Satyridae. Trustees of the British Museum, London.

https://doi.org/10.5962/bhl.title.118835

Robbins R.K., Lamas G., Mielke O.H.H., Harvey D.J. \& Casagrande M.M. 1996. Taxonomic composition and ecological structure of the species-rich butterfly community at Pakitza, Parque Nacional del Manu, Perú. In: Wilson D.E. \& Sandoval A. (eds) Manu. The Biodiversity of Southeastern Peru: 217-252. Smithsonian Institution, Washington DC.

Silva A.R.M., Pontes D.V., Guimarães M.P., Oliveira M.V., Assis L.T.F. \& Uehara-Prado M. 2015. Fruitfeeding butterflies (Lepidoptera: Nymphalidae) of the Área de Proteção Especial Manancial Mutuca, Nova Lima and species list for the Region of Belo Horizonte, Minas Gerais, Brazil. Biota Neotropica 15: 1-9. https://doi.org/10.1590/1676-06032015011814

Strutzenberger P., Brehm G. \& Fiedler K. 2012. DNA Barcode Sequencing from Old Type Specimens as a Tool in Taxonomy: A Case Study in the Diverse Genus Eois (Lepidoptera: Geometridae). PLoS ONE 7 (11): e49710. https://doi.org/10.1371/journal.pone.0049710

Warren A.D., Davis K.J., Stangeland E.M., Pelham J.P. \& Grishin N.V. 2018. Illustrated Lists of American Butterflies. Available from http://www.butterfliesofamerica.com/ [accessed Mar. 2019].

Westwood J.O. 1850-1852. The genera of diurnal Lepidoptera: comprising their generic characters, a notice of their habits and transformations, and a catalogue of the species of each genus. In: Doubleday E. The Genera of Diurnal Lepidoptera: Comprising their Generic Characters, a Notice of their Habits and Transformations, and a Catalogue of the Species of each Genus. Longman, Brown, Green \& Longmans, London. https://doi.org/10.5962/bhl.title.14057

Weymer G. 1911. 4. Familie: Satyridae: 173-283. In: Seitz A. (ed.) Die Gross-Schmetterlinge der Erde 5. A. Kernen, Stuttgart.

Willmott K.R. 2003. The Genus Adelpha: its Systematics, Biology and Biogeography (Lepidoptera: Nymphalidae: Limenitidini). Scientific Publishers, Gainesville.

Willmott K.R., Marín M.A., Nakahara S., Pomerantz T., Lamas G., Huertas B., Espeland M., Xiao L., Hall J.P.W., Willmott J.I.R. \& Freitas A.V.L. 2019. A revision of the new Andean butterfly genus Optimandes Marín, Nakahara \& Willmott, n. gen., with the description of a new species (Nymphalidae: Satyrinae: Euptychiina). Tropical Lepidoptera Research 29 (1): 29-44. https://doi.org/10.5281/zenodo.2650482

Zacca T., Paluch M., Siewert R., Freitas A., Barbosa E., Mielke O.H.H. \& Casagrande M.M. 2017. Revision of Godartiana Forster (Lepidoptera: Nymphalidae), with the description of a new species from northeastern Brazil. Austral Entomology 56: 169-190. https://doi.org/10.1111/aen.12223 
Zacca T., Casagrande M.M., Mielke O.H.H., Huertas B., Espeland M., Barbosa E., Freitas A.V.L., Magaldi L., Nakahara S. \& Willmott K.R. 2018. Systematics of the butterfly genus Cissia Doubleday, 1848 (Lepidoptera: Nymphalidae, Satyrinae) using an integrative approach. Arthropod Systematics \& Phylogeny 76 (2): 349-376.

Manuscript received: 28 May 2019

Manuscript accepted: 9 August 2019

Published on: 13 September 2019

Topic editor: Gavin Broad

Desk editor: Kristiaan Hoedemakers

Printed versions of all papers are also deposited in the libraries of the institutes that are members of the EJT consortium: Muséum national d'Histoire naturelle, Paris, France; Meise Botanic Garden, Belgium; Royal Museum for Central Africa, Tervuren, Belgium; Royal Belgian Institute of Natural Sciences, Brussels, Belgium; Natural History Museum of Denmark, Copenhagen, Denmark; Naturalis Biodiversity Center, Leiden, the Netherlands; Museo Nacional de Ciencias Naturales-CSIC, Madrid, Spain; Real Jardín Botánico de Madrid CSIC, Spain; Zoological Research Museum Alexander Koenig, Bonn, Germany; National Museum, Prague, Czech Republic. 


\section{Appendix}

Resumen. Presentamos la primera revisión taxonómica integral del poco conocido género de mariposas sudamericanas Zischkaia Forster, 1964, hasta ahora considerado como incluyendo três espécies descritas. Un análisis filogenético con base en los datos de secuencia de ADN muestra que Zischkaia es monofilético y consta morfológicamente de dos clados diagnosticables. Los caracteres morfológicos y los "códigos de barras" de ADN respaldan el reconocimiento de doce especies en el género, un aumento significativo para la subtribu Euptychiina que es relativamente poco estudiada. En consecuencia, aquí se describen y nombran nueve especies nuevas: $Z$. arctoa Nakahara, sp. nov., Z. chullachaki Nakahara \& Zacca, sp. nov., Z. baku Zacca, Dolibaina \& Dias, sp. nov., Z. arenisca Nakahara, Willmott \& Hall, sp. nov., Z. argyrosflecha Nakahara, L. Miller \& Huertas, sp. nov., Z. abanico Nakahara \& Petit, sp. nov., Z. josti Nakahara \& Kleckner, sp. nov., Z. mielkeorum Dolibaina, Dias \& Zacca, sp. nov., y Z. warreni Dias, Zacca \& Dolibaina, sp. nov.. Además, se designan un neotipo para Satyrus pacarus Godart, [1824], y los lectotipos para Euptychia amalda Weymer, 1911, Euptychia fumata Butler, 1867, y Euptychia saundersii Butler, 1867.

Resumo. É apresentada a primeira revisão taxonômica de Zischkaia Forster, 1964, um gênero de borboletas pouco conhecido da América do Sul composto, até o momento, por três espécies descritas. Uma análise filogenética baseada em sequências de dados de DNA demonstra que Zischkaia é monofilético e consiste de dois clados diagnosticáveis morfologicamente. Caracteres morfológicos e DNA "barcodes" suportam o reconhecimento de 12 espécies no gênero, um aumento significativo mesmo para a relativamente pouco estudada subtribo Euptychiina. Consequentemente, nove espécies novas são descritas e nomeadas no presente estudo, a citar: Z. arctoa Nakahara, sp. nov., Z. chullachaki Nakahara \& Zacca, sp. nov., Z. baku Zacca, Dolibaina \& Dias, sp. nov., Z. arenisca Nakahara, Willmott \& Hall, sp. nov., Z. argyrosflecha Nakahara, L. Miller \& Huertas, sp. nov., Z. abanico Nakahara \& Petit, sp. nov., Z. josti Nakahara \& Kleckner, sp. nov., Z. mielkeorum Dolibaina, Dias \& Zacca, sp. nov., y Z. warreni Dias, Zacca \& Dolibaina, sp. nov.. Adicionalmente, um neótipo é designado para Satyrus pacarus Godart, [1824] e lectótipos são designados para Euptychia amalda Weymer, 1911, Euptychia fumata Butler, 1867 e Euptychia saundersii Butler, 1867. 